Denis Nosnitsin

Hamburg University

\title{
WÄWÄHABO QOB'A WÄ̈ASKEMA...: REFLECTIONS ON AN EPISODE FROM THE HISTORY OF THE ETHIOPIAN MONASTIC MOVEMENT
}

Among the traditions transmitted in Ethiopian hagiographic works, those referring to the encounters between Täklä Haymanot ${ }^{1}$ and Iyäsus $\mathrm{Mo}^{5} \mathrm{a}^{2}$ two late $13^{\text {th }}$-/early $14^{\text {th }}$-cent. monastic leaders and great Ethiopian saints -

${ }^{1}$ There is no need to quote all existing scholarly literature on Täklä Haymanot's activities, hagiography and cult, or all works on the history of his monastic foundation, Däbrä Libanos of Šäwa. These topics have been discussed in a number of publications, ranging from brief entries in reference-books to chapters in monographs [for the list of abbreviations used in this article see p. 239]: s., e. g., BHO 247-248, nos. 1128-1134; Cerulli 1943:228-232; TAdDESSE TAMrat 1972:160-169; DEB 157-158; KRZ92-93, no. 151; KRISS — KRISS HEINRICH 1975:30-41; among the recent publications, s., e. g., Böll in: LTK IX, 1244-1245; TedesCHI in: EnSanti II, 1132-1138; DERAT 2003, passim. On the hagiographic legend of Täklä Haymanot, s. Derat 1998, NOSNITZYN 2003 (concerning the hagiographic reports on the Saint's translatio), NoSNITSIN 2006, forthcoming (on the Synaxarion commemorative note about the Saint). Let us only recall that, according to the more or less commonly accepted chronology, Täklä Haymanot is thought to have lived in ca. 1214/15-1313; the Saint's major annual feasts are celebrated on 24 Nähase (obitus) and 12 Gonbot (translatio).

${ }^{2}$ As is commonly known, abba Iyäsus $\mathrm{Mo}^{3} \mathrm{a}$ was one of the most prominent representatives of Däbrä Hayq Jsțifanos, which, like Däbrä Libanos of Šäwa, is today one of the most venerated monasteries of Ethiopia. However, Iyäsus $\mathrm{Mo}^{\circ} \mathrm{a}$ appears to have been somewhat less popular than a number of other holy monks. The rather local character of his cult becomes evident when compared to the countrywide veneration of Täklä Haymanot, Gäbrä Mänfäs Qəddus, Samu’el of Waldəbba, Zä-Mika ${ }^{2}$ l Arägawi, as well as of several other Oriental saints. Iyäsus Mo'a’s commemoration is recorded in the Synaxarion, but only in a short notice (26 Hodar), not in a hagiobiographic account. His popularity could have been increased by hagiographies of other saints, where he is mentioned as a prominent monastic leader; yet, the considerable difference between the respective cults of Täklä Haymanot and Iyäsus $\mathrm{Mo}^{\circ} \mathrm{a}$ is demonstrated, e. g., by the number of manuscripts containing their hagiographies. Whereas Täklä Haymanot's hagiographic tradition, represented by a substantial number of works, is attested by many dozens of manuscripts, the same cannot be said about the tradition of Iyäsus $\mathrm{Mo}^{\circ} \mathrm{a}$ (s, e. g., DEB 92; TAdDESSE TAMrat 1970:8891; KRZ 78-79, no. 86; MARRASSINI 1986; TedeSCHI in: EnSanti II, 267-271; Baum in: $B K K \mathrm{XX}, 804-806)$. 
are considered central for the reconstruction of medieval Ethiopian church history. This is reflected in the well-known evaluation given by Taddesse Tamrat of one such episode: «His [sc. Täklä Haymanot's] encounter with Iyäsus-Mo'a on this second occasion is shrouded with uncertainties in the traditions, and has become one of the most controversial points in Ethiopian ecclesiastical history. The controversy basically evolves around the mutual claims of seniority later advanced by Däbrä Hayq and Däbrä Lībanos». ${ }^{3}$ This «controversy» has been the subject of a number of studies; yet, the progress made in the understanding of Ethiopian history and the growing number of accessible sources offers an opportunity to assess the problem one more time, at the cross-roads of historical and philological studies. Today, a deeper analysis of the relevant hagiographies is possible, with the aim not only of coming closer to the reconstruction of the late $13^{\text {th }}$-cent. events, but also of tracing the development of the traditions within their original context, their sources and interrelations - thus correctly assessing their value. The present essay is an attempt at such analysis. ${ }^{4}$

\section{I}

Before embarking on the analysis, interpretation and evaluation of the accounts I would like to summarize the most important points and acting characters of the story, according to its «classical» version as transmitted by the early-16 ${ }^{\text {th }}$-cent. Vita of Täklä Haymanot in the recension of Däbrä Libanos. ${ }^{5}$

Obeying the Lord's command, ${ }^{6}$ Täklä Haymanot, who had converted large numbers of pagans in the south of the Ethiopian kingdom and worked miracles, sought to take on the monastic habit and learn the «monastic rules».

${ }^{3}$ TAdDesse TAmrat 1972:164.

${ }^{4}$ The essay is drawn from my Ph.D. thesis, «The Vita of Täklä Haymanot as a monument of Ethiopian medieval literature», completed under the supervision of the late Sevir B. Chernetsov and defended at the Oriental Faculty of St. Petersburg State University on 20 December 2002.

${ }^{5}$ From here on, the text of the Vita of Täklä Haymanot in the Däbrä Libanos recension is quoted after the editio princeps, BUDGE 1906; however, one should note that this text represents not the original but a slightly reworked variant of that recension (a problem I have addressed on several occasions: e. g., Nosnitsin 2006, forthcoming, cp. also n. 34, below). The translation provided in BudGE 1906 is often erroneous; when referring to it, I will attempt, therefore, to rectify it (and simplify the transcription of proper names).

${ }^{6}$ The summary follows BudGe 1906, chs. 68-88 (particularly relevant are chs. 68-75, 77-81, 85-88). In the Däbrä Libanos recension of his Vita, Täklä Haymanot's monastic career does not appear as detailed and lengthy as one would expect considering the time (more than 30 years) Täklä Haymanot spent in different monasteries (s. the synopsis in BudGe 1906, ch. 113; 10 years in the community of Bäșälotä 
In order to fulfil his predestination - the foundation of the monastery of Däbrä Asbo/Libanos — Täklä Haymanot was deemed to become a monk. Since there are no monasteries in Säwa, he travelled to the north of Ethiopia, seeking to assume the monastic habit there. The first place where he made a halt is that of abba Bäșälotä Mika el «of Gəšše», the head of a (unidentified) monastery in Amhara. ${ }^{7}$ Täklä Haymanot spent ten years there;

Mika ${ }^{\circ}$ el [Amhara], 10 years at Däbrä Hayq Esțifanos, 12 years at Däbrä Dammo, 1 year wandering in Təgre and Jerusalem, 29 years in Däbrä Asbo; in manuscripts, there are some differences concerning the last period).

${ }^{7}$ While the historical context of the episode is more or less clear (cp. TADDESSE TAMRAT 1972:112-117, 177-178), the chronology and historical identity of abba Bäșälotä Mika ${ }^{2}$ l is difficult to ascertain. According to the Synaxarion recension of Täklä Haymanot's Vita — which is probably one of the most ancient hagiographic sources on the Saint (s. Nosnitsin 2006, forthcoming) — Bäșälotä Mika el was the only spiritual teacher of Täklä Haymanot and it was he, one could presume, who imposed the «monkish yoke» upon Täklä Haymanot (s. Guid 1912:381). However, the Waldəbba recension of Täklä Haymanot's Vita does not mention Bäșälotä Mika el at all, while in the Hayq and Däbrä Libanos recensions Bäṣälotä Mika el is styled as Bäșälotä Mika el zä-hagärä Gəsse (e. g., in MS Paris, Bibliothèque national de France, éth. 342 = Griaule 38 [s. below], fol. 89vb; however, he is «Bäșälotä Mika el of Amhara» on fols. 85va, 87ra) and Bäṣälotä Mika el zä-Gəššä (BudGe 1906, ch. 68) respectively. It is difficult to identify him as «Bäșälotä Mika ${ }^{2}$ l of Däbrä Gol» whose hagiography was edited by C. ConTI Rossini (1905), and who was the spiritual father of Aron of Däbrä Daret (cp. Turaiev 1908:125; EAE I, 350f.). Däbrä Gwäl of Amhara - a historical monastery identical, according to the Vita of Bäșälotä Mika ${ }^{3}$ el, to Däbrä Șəmmona, where Bäșälotä Mika ${ }^{2}$ l assumed the monastic habit from Anorewos and lived (Conti Rossini 1905:14; there he lays the monastic habit upon Aron) can hardly be identified with the well-known monastery of Däbrä Bahrryy (in Gassəççăa, domain of $a b b a$ Giyorgis of Gassəçç̣a/Sägla), the contemporary site of Bäșälotä Mika ${ }^{2}$ l's cult, where his relics were transferred from G[ $\left.{ }^{\mathrm{w}}\right]$ əlo Mäkäda (northeastern Təgray; s. ConTi Rossini 1905:50-53; SAUTER 1963:275). The identification of Gəšše (the region where the important church of Mäkanä Śəllase was situated) with Gassəčça is also problematic, though it is favoured by the local tradition (this identification, recorded in the Acts of Bäșälotä Mika ${ }^{2}$ el preserved in Däbrä Bahrrəy of Gassəçç̣a [s. DERAT 2003:116-117], may in fact originate from the Acts of Täklä Haymanot; however, the monastic library of Däbrä Bahrəy needs further investigation). In any case,

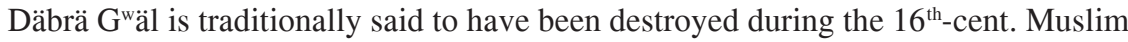
war and never rebuilt; its precise location remains unknown. In his hagiography, Bäșälotä Mika ${ }^{j}$ l appears as the contemporary of Metropolitan abunä $\mathrm{Ya}^{\mathrm{c}}$ əqob and King ${ }^{\mathrm{c}}$ Amdä Şəyon I (1314-1334), as a strenuous opponent of the latter and reformer of the Church and monastic life (s. EAE I, 493f.). Thus, there seems to exist more reasons to distinguish between «the early» Bäșälotä Mika ${ }^{2} e l$ of Gəšše (mentioned in the hagiographic legend of Täklä Haymanot) and «the later» Bäșälotä Mika el of Däbrä Gwäl (as proposed by TuRAIEv 1902:53; s. also Getatchew Haile's commentary to MS EMML 1834, fol. 93b). The Vita of Iyäsus Mo'a seems to conflate «earlier» and «later» personages, while stating that Iyäsus $\mathrm{Mo}^{\circ} \mathrm{a}$ was the spiritual father of Bä- 
thereafter he proceeded to $a b b a$ Iyäsus $\mathrm{Mo}^{\circ} \mathrm{a}$, the abbot of the famous community of Däbrä Hayq Gsțifanos. Iyäsus $\mathrm{Mo}^{\circ} \mathrm{a}$ accepted Täklä Haymanot and vested the new disciple with the «monkish garb», becoming his «spiritual father».$^{8}$ After ten years at Däbrä Hayq Hsțifanos, an angel appeared to Täklä Haymanot with a message from God: he should visit other monastic communities and learn the monastic rules; besides, he should go to the monastery of Däbrä Dammo (the place where Iyäsus $\mathrm{Mo}^{\circ}{ }^{2}$ had taken his monastic habit) and receive from its head, $a b b a$ Yohanni, ${ }^{9}$ the monastic cap ( $q \circ b^{9}$ ) and scapular (askema), and obtain therewith «the complete monk's habit». When taking his farewell from Täklä Haymanot, Iyäsus $\mathrm{Mo}^{\circ} \mathrm{a}$ asked Täklä Haymanot to bring the monastic cap and scapular also for him, since he had left Däbrä Dammo without receiving these parts of the monastic garb from abba Yohanni. Iyäsus $\mathrm{Mo}^{\mathrm{j}} \mathrm{a}$ was aware of the circumstance that, in case his request was fulfilled, his «spiritual son» would formally become his «spiritual father». ${ }^{10}$ Täklä Haymanot reached then

șälotä Mika ${ }^{2} \mathrm{el}$ «who preached in the entire (country of) Amhara being in the land of

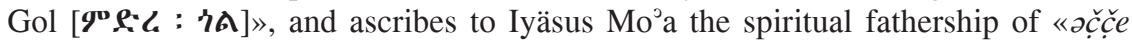
`Aron of Däbrä Därit» (KuR 1965:34-35 [text]).

${ }^{8}$ BUdGE 1906, ch. 75; Iyäsus Mo ${ }^{3}$ receives from an angel the command to vest

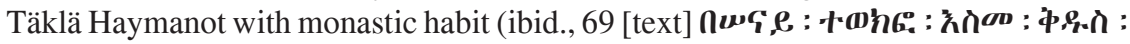

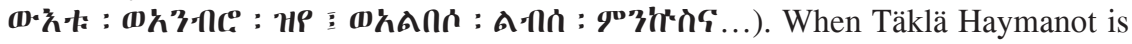
introduced to him, Iyäsus $\mathrm{Mo}^{\mathrm{D} a}$ mentions that he has been directed by the angel, yet Täklä Haymanot should stay and wait a little bit. Soon, the Abbot vested him with the

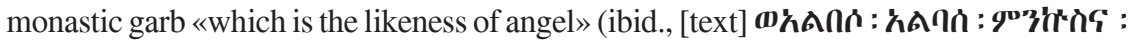

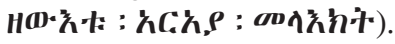

${ }^{9}$ TAdDESSE TAMrat 1972:158-159, 163, 165-166; DEB 189; Tedeschi in: EnSan$t i$ II, 1362-1363. Historiographical notes attached to the Vita of Zä-Mika ${ }^{2} e l$ Arägawi (Guid 1895:34, 42; s. below) appear to be the primary source on Yohanni, where he is the seventh after Zä-Mika ${ }^{2}$ l, the founder of Däbrä Dammo (this being «chronologically impossible», s. TADDESSE TAMRAT 1972:158, n. 4), but only the Vita of Iyäsus $\mathrm{Mo}^{\circ}$ a presents an extended hagiographic account of $a b b a$ Yohanni's life. Apart from this, he seems to be less known and should not be confused with $a b b a$ Yohanni of Däbrä Sina of Sänhiit (Kärän, Eritrea), or abba Yohanni from Däbrä ${ }^{c} A s a$ (Təgray). Considering the name «Yohanni» and its similarity to Coptic names (Marrassini 1990:37), one should notice that «Yohanni» can also be explained from the point of view of Ethiopian onomastics, as a contracted form of the Ethiopic name Yäwhanni («[the Lord] has been merciful to me», this variant having been recorded on wall paintings in the ancient Gännätä Maryam church, s. BALICKA-WITAKOWSKA 19981999:189, n. 56).

${ }^{10}$ BUDGE 1905, ch. 77, with «oil» and «(monastic) garb» standing for $q o b^{c}$ and askema respectively. The passage reads: «[And Iyäsus $\mathrm{Mo}^{\circ} \mathrm{a}$ said to Täklä Haymanot:] Why are you leaving me? I have not seen you like a son, for I have seen you like a honourable father. Nevertheless your words about going to my mountain have pleased me, and when you arrive there [you] will receive the (monastic) cap and scapular; and afterwards you yourself will give (them) to me, and you will become me a father». 
Däbrä Dammo and told $a b b a$ Yohanni that he received his monastic garb from Iyäsus $\mathrm{Mo}^{\circ} \mathrm{a}$. Stating that Täklä Haymanot is «the (spiritual) son of his son», Yohanni bestowed upon him the qob ${ }^{c}$ and askema. ${ }^{11}$ After visits to other monastic communities of northern Ethiopia and three miraculous travels to Jerusalem, Täklä Haymanot, following God's command, returned to Däbrä Hayq Gsțifanos and handed the monastic cap and scapular over to Iyäsus $\mathrm{Mo}^{3} \mathrm{a}$, in accordance with the latter's will. ${ }^{12}$

At the end of the account, there is a fragment containing Täklä Haymanot's monastic pedigree beginning with Anthony the Great, in which the «spiritual kinship» between the three holy monks — Iyäsus $\mathrm{Mo}^{ } \mathrm{a}$, Yohanni and Täklä Haymanot — is explained once again; however, referring to Täklä Haymanot, the hagiographer or deliberately leaves out or forgets to mention, from whom the Saint received the parts of the monastic habit of the first grade («monastic clothes» - from Iyäsus $\mathrm{Mo}^{\circ} \mathrm{a}$ ). However significant this contradiction might be, we can not say that this pedigree «reverses» the preceeding account. ${ }^{13}$

It seems that this version of the story first became widely known because of the popularity of the Däbrä Libanos recension of Täklä Haymanot's Vita.

${ }^{11}$ Budge 1905, ch. 78. Before vesting Täklä Haymanot with the monastic cap and garb, abba Yohanni questions him; after that, he performs the consecration rite: «And he [abba Yohanni] said: What is your name, and who vested you with the monastic

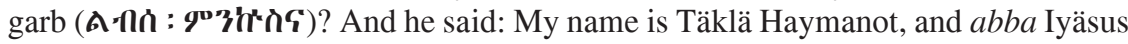
$\mathrm{Mo}^{\circ} \mathrm{a}$ who dwells on an island of the lake, endowed me with the garb of the monk. And $a b b a$ Yohanni said: Verily you are son of my son, for I begot him by the Holy Ghost. And $a b b a$ Yohanni prayed over the cap and scapular according to the law

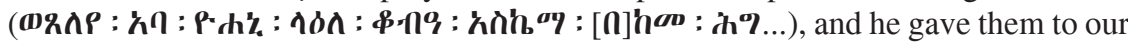
father holy man Täklä Haymanot».

${ }^{12}$ Budge 1905, ch. 87, 188-189 [tr.]: «And on the morrow he rose up and departed, and he came to the place on the sea-shore, and he walked upon the water, even as a man walketh on the dry land; and he came unto Iyasus $\mathrm{Mo}^{\circ} \mathrm{a}$. And when the Abbot saw him, he rejoiced exceedingly, and said unto him, "Where didst thou receive the

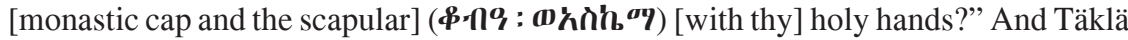
Haymanot said unto him, "In Mount Damo, at the hand of Abba Yohanni". And [he] said unto him, "From this time onward I will cease from the toil of the road; I will be thy son, and thou shalt be [my] father; give me the [monastic cap and the scapular] which are in thy holy hands". And [Abba Täklä Haymanot] gave [him] the cowl [the monastic cap] and the cloak, for the angel said unto him, "Hearken unto what he sayeth unto thee"».

${ }^{13}$ Cp. Derat 2003:106-107; s. Budge 1906, ch. 88, with the somewhat vague title «How the garb of the monk and the rule of ascetic life descended from Anthony to Takla Hâymânôt» (ibid., 189-190 [tr.]): «....and Abba Mäsqäl Moª begot Abba Yohanni, and Abba Yoḥanni begot Abba Iyäsus $\mathrm{Mo}^{\circ} \mathrm{a}$ and Täklä Haymanot, [Iyäsus

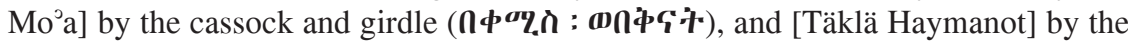
[monastic cap and the scapular]; and Abba [Täklä Haymanot gave Iyäsus $\mathrm{Mo}^{\circ} \mathrm{a}$ the monastic cap and the scapular], even as we have said before». 
Yet, this story — in particular its conclusion, which makes Täklä Haymanot the «spiritual father» of Iyäsus $\mathrm{Mo}^{\circ} \mathrm{a}$, the latter having had no monastic cap or scapular before - was emotionally refuted in another hagiography, the Vita of Iyäsus $\mathrm{Mo}^{\mathrm{a}} \mathrm{a}$. This work is considered to reflect the point of view of the monastic community of Däbrä Hayq Jsțifanos; it summarizes Täklä Haymanot's biography, seeking to prove that the case was only that Täklä Haymanot gave Iyäsus $\mathrm{Mo}^{\circ}$ a the scapular. The same story is repeated, with some variants, in other hagiographic texts (the Waldəbba and Hayq recensions of the Vita of Täklä Haymanot, the Vita of Zä-Mika ${ }^{2}$ l Arägawi), and mentioned in many other sources. As the most important of these texts were edited, the episode in question attracted considerable scholarly attention, mainly to the aim of reconstructing the sequence of developments and ascertaining which of the two holy monks, Täklä Haymanot or Iyäsus $\mathrm{Mo}^{5} \mathrm{a}$, held superiority concerning the parts of the monastic habit. Different interpretations of the story resulted in varying understandings of the roles Däbrä Libanos of Šäwa and Däbrä Hayq Usțifanos played in Ethiopian medieval church history. The question became even more delicate from the beginning of the $20^{\text {th }}$ cent., when Täklä Haymanot, Iyäsus $\mathrm{Mo}^{\circ} \mathrm{a}$ and Zä-Mika ${ }^{2}$ l Arägawi were raised to symbols of Ethiopian Christianity by the Ethiopian Orthodox Täwahədo Church.

Summarizing the main points of the studies, one should note that, whereas the encounters of Täklä Haymanot, Iyäsus $\mathrm{Mo}^{\circ} \mathrm{a}$ and Zä-Mika ${ }^{\circ}$ l Arägawi the prominent $13^{\text {th }}-14^{\text {th }}$-cent. monastic leaders — are generally thought to have been historical events, there is a commonly accepted view that hagiographical accounts must be approached critically and evaluated as both historical events and fictional products. ${ }^{14}$ The prevailing tendency today is to refrain from the positivistic enquiry into the episode as described in the hagiographies (including the monastic investiture performed by the «spiritual son» Täklä Haymanot upon his «spiritual father» Iyäsus $\mathrm{Mo}^{\circ} \mathrm{a}$ ), and attempts to find out who precisely conferred particular parts of the monastic habit upon

${ }^{14}$ S. KAPLAN 1986; cp. E. Cerulli's remark in the preface to the Vita of Iyäsus Moª (KUR 1965:v-VI [tr.]): «Un cliché commun dans l'hagiographie éthiopienne sont les rencontres du saint dont on écrit la Vie, avec d'autres saints personnages de l'Église qui sont de la même époque ou plutôt qu'on peut vraisemblement attribuer à la même époque» (cp., however, on the possible historical background of such episodes, CERUlli 1958:271). The establishment of the identities of the characters interacting with the protagonist of a Vita is thus a common subject of hagiographical. While pursuing this task, scholars define possible chronological and historical frames of the narrated events and establish the historical value of hagiographic accounts. In many cases, reports about encounters of holy monks can be counter-checked against other hagiographic traditions. The results, however, are different depending on the type of individual hagiographic work in question. Cp. the typology of such accounts in MARRASSINI 1981:XCIII-C («incontri con personaggi del passato», «incontri con personaggi ‘contemporanei'»). 
whom, when and where. ${ }^{15}$ One would rather prefer to consider this story as a reflection of a particular historical process, namely the rivalry between Däbrä Libanos of S̈äwa and Däbrä Hayq Hsțifanos that started presumably some time after the death of both saints and left traces in their hagiographies, the episode in question being one of the main pieces of evidence. As a result, the accounts with that story have been carefully investigated in order to find the idea of (spiritual) superiority expressed therein that was thought to have been functional to earning and consolidating religious and political influence. ${ }^{16}$ For the later period, the alleged rivalry is fitting with the political and religious context of the Gondärine kingdom, with the inner struggle of the «houses» of Täklä Haymanot and Ewosțatewos. ${ }^{17}$ The idea of the superiority of

15 TAdDESSE TAMrat (1972:165 and n. 5) thinks that the story of Täklä Haymanot handing over the monastic cap and scapular to Iyäsus $\mathrm{Mo}^{\circ} \mathrm{a}$ is the result of an inconsistent usage of terminology and should not be given historical credibility. Monastic canons render it impossible that a disciple could perform the monastic investiture upon his spiritual father. In Taddesse's opinion, the system of the grades of monastic habit was introduced in Ethiopia at a later point: «It appears, however, that these rules of gradual investiture were of a relatively recent date»; in the $13^{\text {th }}-14^{\text {th }}$ cent. the novice was supposed to assume the «monastic yoke» only once. Taddesse, pointing to the Vita of Zä-Mika ${ }^{2}$ el Arägawi as the central source, considers the episode in question to be partly a result of some sort of «confusion» and partly a kind of «literary invention» of the hagiographer, which was subsequently introduced into other hagiographic works: «This Däbrä Damo tradition seems to be the original source of all the controversy, and was apparently invented by an over-zealous scribe of the monastery to stress the historical fact that both Iyäsus-Mo'a and Täklä-Haymanot derived their monastic origin from the house of Abunä Arägawī» (TADDESSE TAMRAT 1972:166). It is remarkable that in his important study on the abbots of Däbrä Hayq Gsțifanos, Taddesse does not discuss the episode, only characterizing the relevant passage of the Vita of Iyäsus $\mathrm{Mo}^{\circ} \mathrm{a}$ as a «highly polemical» one (TADDESSE TAMRAT 1970:89, n. 13).

${ }^{16}$ As early as 1898, Vasilij Bolotov, the Russian historian of the Early Church, suggested that versions of the story concerning the spiritual relationship between Iyäsus $\mathrm{Mo}^{\circ} \mathrm{a}$ and Täklä Haymanot and their taking parts of the monastic habit reflect

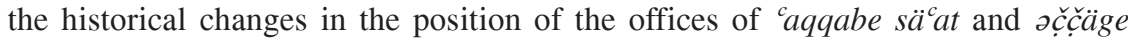
respectively (Bolotov 1898:195, n. 12). Cp. Derat 2003:105: «La substitution progressive de Täklä Haymanot à Iyäsus Mo'a, dès le début du XVIe siècle, est le signe que les communautés de ces deux saints étaient concurrentes... Il s'agit d'un affrontement entre les deux communautés monastiques, par texte interposé, à la fin du XV et au début du XVI ${ }^{\mathrm{e}}$ siècle». Perhaps, the same view stands behind the statement in Six 1975:27-31, esp. 29 and n. 50, where it is said that the head of Däbrä Hayq Bsțifanos was invested with the title and office of ə⿳亠丷厂̣⿱äge already under the King ${ }^{\mathrm{c}}$ Amdä Șəyon I (1314-1344), which was transferred to the head of Däbrä Libanos during the reign of Zär ${ }^{\circ a} Y^{c}{ }^{c}$ əqob after 1445.

${ }^{17}$ M.-L. Derat came to the conclusion that different variants of the story in question reflect the early stage of the «rivalry» between Däbrä Libanos and Däbrä Hayq Gsțifanos, the later being reflected in the Bə ${ }^{c}$ əlä Nägäśt, the narrative about the reestab- 
«the spiritual father» over his «son» can therefore be interpreted in terms of the actual - religious and administrative - submission of one monastic community to another. If applied to the case of Däbrä Hayq Hsțifanos and Däbrä Libanos of Šäwa, this concept provides, a priori, a well-structured picture for a long period of the Ethiopian church history. ${ }^{18}$ It is clear, however, that the acceptance of one all-embracing model does not remove either the task of a comparative evaluation of all the pieces of evidence or the need to reveal and explain, as far as possible, all the contradictions and discrepancies between them. ${ }^{19}$

A closer look at Ethiopian hagiography reveals that monastic initiation is often featured in the biographical accounts of Ethiopian saints. However, in most cases hagiographers record the mere fact of the assumption of the monastic habit. While describing how the protagonist enters monastic life, they mention sometimes the monkish «tunic» or robe (qämis), more frequently girdle (qənat), «monastic cap» $\left(q o b^{c}\right)$ and scapular (askema), or simply un-

lishment of the Solomonic dynasty (in which the role that originally belonged to abba Iyäsus $\mathrm{Mo}^{\circ} \mathrm{a}$ is taken over by Täklä Haymanot: «one third of the kingdom», thought to have been previously promised to Däbrä Hayq, is promised to Däbrä Libanos), and is thus to be dated to the late $17^{\text {th }}$ or early $18^{\text {th }}$ cent. (DERAT 2003:97-98). A passage of the «monastic chronicle» of Däbrä Libanos (Zena Däbrä Libanos) is considered to be important in this connection, since it may present the core of the story to be later developed in the Bə⿱⺊ `əlä Nägäs't (the account of Täklä Haymanot's intervention in the political struggle and his intercession on behalf of Yəkunno Amlak), and contain allusions to the «testaments» in the Vita of Iyäsus $\mathrm{Mo}^{\circ}$ a (ibid. 102103). Regarding the episode under enquiry, M.-L. Derat encounters a difficulty since she accepts the dating suggested by E. Cerulli: «En effet, les actes du Iyäsus Mo'a datant de la fin du $X^{\mathrm{e}}$ siècle apparaissent comme une réponse des auteurs des Hayq à ceux de Täklä Haymanot rédigés au début du $\mathrm{XVI}^{\mathrm{e}}$ siècle. Soit la réponse des auteurs de Hayq est postérieure à la rédaction de la Vie de Iyäsus Mo'a, et représente un remaniement de ce texte après le début du $\mathrm{XV}^{\mathrm{e}}$ siècle. Soit, du côté de Däbrä Asbo/ Libanos, la vie de Täklä Haymanot a connu des version intermédiaires entre le début du $\mathrm{XV}^{\mathrm{e}}$ siècle et le début du $\mathrm{XVI}^{\mathrm{e}}$ siècle, dans lesquelles le rattachement de Däbrä Asbo/Libanos à Däbrä Hayq fut d'abord affirmé, puis nuancé par l'épisode du qob et de l'askéma» (DERAT 2003:109; s. below).

${ }^{18}$ This interpretation of the episode with Täklä Haymanot and Iyäsus Mo Ma, with the subsequent conclusions concerning the relations between Däbrä Hayq Gsțifanos and Däbrä Libanos of Šäwa, would fit into the picture of the development of Ethiopian monastic movement as presented by E. CERULLI 1958:270-273.

${ }^{19}$ E. g., Turaev pointed out that the suggestion of Bolotov concerning the «rivalry» between the offices of ə⿳亠丷厂̣⿱äge and ${ }^{c}$ aqqabe sä $\ddot{c}^{c} a t$ (s. above, n. 16) can not be fully supported by the evidence from the hagiographic tradition of Täklä Haymanot: the early Waldəbba version of Täklä Haymanot's Vita has the «controversial episode», whereas it is missing in the more recent Synaxarion note on Täklä Haymanot, 24 Nähase (Turaiev 1902:96). 
specified monastic garb or clothes (ləbsä/albasä/mälbäsä mənk ${ }^{w} ə s ə n n a$ or $a r^{c} u t a ̈$ [lit. «yoke»] mənk $\left.{ }^{w} ә s ə n n a\right){ }^{20}$ Yet, the exact listing of all the insignia received by a saint in the course of his monastic career or the precise recording of respective bestowing rituals were not considered obligatory; in a few cases, the mention of the monastic initiation is missing altogether. ${ }^{21}$ Hagiographers apparently wanted to attract more attention to the religious and ethical value of the monastic vow and ensue moral responsibilities and obligations. Consequently, most of the relevant episodes appear in the form of brief, loosely formalized hagiographic «common places», which only occasionally include more details. ${ }^{22}$

${ }^{20}$ According to traditional sources, these are parts of the monastic habit and, at the same time, insignia designating the grades of the monastic profession, up to the askema, for the «perfect monk». The qämis is the traditional long shirt (or «tunic»), usually made of undyed material (cp. GuIDI 1901:248; cp. also KBT 359). The qənat is a rough leather (or fibre) belt but frequently nothing else but a simple rope (GuIDI 1901:283; cp. KBT 387). The $q o b^{c}$ (Amharic: $q o b$ ) is a round, flat-topped cap without brims, made of white or black material (GuIDI 1901:274; KBT 437; cp. an Amharic idiom yäqob səm «monastic name»). The askema consists of two leather strips hanging over the shoulders and crossed on the back and breast, with 12 small crosses hanging from it (GuIDI 1901:446; cp. KBT 729, s. «Askema»; «Clothing: Ecclesiastic» in: $E A E$ I, 373, 761-763). The term derives from Greek $\sigma \chi \hat{\eta} \mu \alpha$ «habitus, species» (s. Leslau 1987:43; cp. Dillmann 1865:752), this clarifying the meaning of such

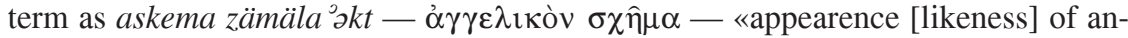
gel». The askema-scapular symbolises the third, highest grade of the monastic profession, at which the monk reaches the highest degree of purity and obtains the «angelic nature» (cp. KAPLAN 1984:81-83; cp. HAMMERSCHMIDT 1962:221). All parts of the Ethiopian monkish apparel have parallels in other (Oriental) Christian traditions (cp. the similar composition of the monastic habit in the Byzantine typika, Thomas Constantinides Hero 2000, vol. 1, XXII).

${ }^{21}$ For the typology of this motive as presented in Ethiopian hagiography, s. Appendix, with examples from some 22 hagiographies.

${ }^{22}$ The terminology used there is, indeed, not quite consequent, yet the accounts are clear and transparent. There is seemingly no difference in the use of the term $l ə b s$ and its plural albas, which mean all the parts of the monastic habit together, with the exception of the scapular. The term askema (monkish, holy, angelic — zämänäkw ${ }^{w}$ sat, qəddəst, zämäla $ə k t$ ) may appear as a potential source of uncertainty, referring to both the monastic life in general (as equivalent for $a r^{c} u t a ̈ ~ m ə n k^{w} ə s ə n n a$ ) and the scapular as the highest («angelic») grade of the monastic profession in particular. In fact, the askema symbolizes the monastic profession and monastic life; «to take on the askema» may simply mean «to enter monastic life», but also «to assume the scapular [the angelic habit]». Yet in the sources the term askema is only ambiguous in a few cases (s. Appendix: Gäbrä Mänfäs Qəddus, Yəsḥaq/Gärima, Libanos/Mätța ${ }^{c}$, Nine Saints in the Vita of Zä-Mika el Arägawi). For a similar problem in Byzantine monastic documents s. Thomas - Constantinides Hero 2000, vol. 1, 155, n. 1; cp. also the Coptic monastic rite, EvetTs 1906:64. 
The attempts at regarding the hagiographic accounts of monastic consecration as reflections of a real practice lead to conclusions concerning the organization of the Ethiopian monastic institutions. The hierarchical order of monastic communities based on the three grades of the monastic profession does not appear to have been commonly accepted across Ethiopian monastic communities, because of the decentralised character of Ethiopian monasticism and the absence of a strong Church organization. ${ }^{23}$ However, it can be assumed that the idea of the monastic investiture and the corresponding rituals could have been known in Ethiopia even before the re-establishment of the Solomonic line (ca. 1270). ${ }^{24}$ From the $14^{\text {th }}$ cent. onwards the gradual monastic investiture (this being nothing but the formal expression of the basic principle of the progressing spiritual contendings, shared by all monastic traditions) possibly gained wider circulation. The assumption of the girdle, tunic and «monastic cap» at one time and the scapular at another time would thus correspond to the custom of distinguishing between the «little habit» and the «great habit». However, a few hagiographies (among them those re-

${ }^{23}$ TADDESSE TAMrat 1972:165.

${ }^{24}$ The tradition of the book of monastic consecration rites known as Śr ${ }^{c} a t a ̈$ Mənk ${ }^{w}$ əsənna («Rule[s] of the Monasticism») or Mäṣhafä Mənk ${ }^{w}$ əsənna («Book of the Monasticism»), preserved in many manuscripts, may well go back to the $14^{\text {th }}$ cent. (cp. MSS EMML 2093, 2168, 2272, 2459; HAMmERSCHMIDT - Six 1983:197-198, no. 103; Six 1989:73, no. 42; cp. a probably $15^{\text {th }}$ cent. MS of the Sər ${ }^{c} a t a ̈$ Monkw 2 sənna from Däbrä Dammo, STRELCYN 1976:323-323, no. 131; cp. also for the same work MS Paris, Bibliothèque national de France, éth. 80, Zotenberg 1877:85, no. 79). The book could have also been composed at an earlier time (RICCI 1969a: 816-817). GRÉBAUT (1940) edited and translated the monastic rite after the $14^{\text {th }}$ - / early $15^{\text {th }}$-cent. MS éth. 80 (Zotenberg 1877:85, no. 79; s. Uhlig 1988:287); though this Śr ${ }^{c} a t \ddot{a}$ Mənk ${ }^{w}$ əsənna is not complete, there are chapters devoted to the ritual of cutting the hairs of the novice (GRÉBAUT 1940:227) and the prayer over the monastic garb (⿻上丨तn,

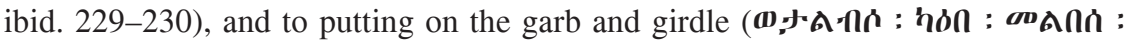

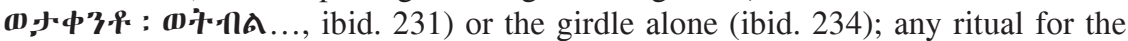
askema is unfortunately missing. The Śr $r^{c}$ atä mənk $k^{w}$ əsənna in MS EMML $1950\left(17^{\text {th }}\right.$ $18^{\text {th }}$ cent., Däbrä Hayq Gsțifanos) is much more developed and contains not only the rites but also the regulations concerning monastic life: e. g., on fol. 1ra-rb it is stated

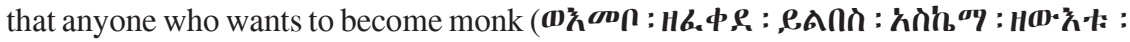

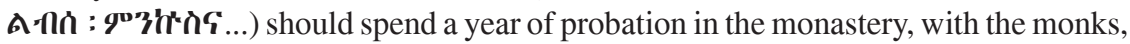
his conduct and qualities being carefully studied and checked by the community. The probationer himself must consider the seriousness of his intention concerning the as-

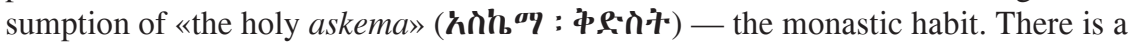
description of the monastic initiation ritual: when the probationer is found worthy of becoming a monk (after the time of probation is over, and only if he has reached the age of 40 years!), the monastic rules are read to him (fol. 1vb). Then, at night, he is taken to the altar, here the ritual of the assumption of the «vestment of askema»

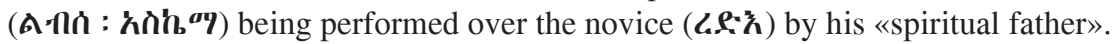


lated to the tradition of Däbrä Libanos) clearly speak of the separate assumption of the scapular, whereas the majority of the sources do not, proving to be indifferent to the question. On the whole, the sources produce no substantial evidence on the introduction of the strict «twofold» monastic consecration as a result of «reforms», ${ }^{25}$ though it is known that active attempts to reorganize some spheres of monastic life did take place. At the same time, hagiographies reflect a range of different attitudes to the «monastic career» in general. ${ }^{26}$

With regards to the Ethiopian monastic tradition as reflected by hagiography, one can not say that the current monastic practice basically disagrees with the information originating from the sources. ${ }^{27}$ At the same time there are same obvious discrepancies which are not easy to explain. For instance, it has been repeatedly reported that, especially in the countryside, the mode of clothing of clergy and monks hardly differs from that of laymen; a distinctive feature of the monk or priest, besides the cap (qob), may be the turban (mattamtamiya), and for monks, of course, the cloak or «mantle» made of

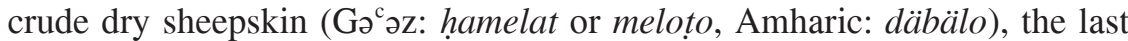
two items excluded from the monastic ritual and rarely appearing in hagiographies. ${ }^{28}$ However, at least in contemporary Ethiopian monastic practice,

${ }^{25}$ Repetition of the ritual would raise concern about its «desacralisation». In Byzantine monastic tradition, e. g., there was a controversy about the «duplication» of the assumption of the monastic habit, which some monastic leaders considered unacceptable like the repetition of Baptism; consequently, they rejected the distinction in the monastic dress: s. Thomas - Constantinides Hero 2000, vol. 1, 78; 155, n. 1, 2; vol. 2, 1203.

${ }^{26}$ They were not always only positive. In fact, in many hagiographic accounts hermits appear as «spiritual athletes» (like $a b b a$ Gäbrä Mänfäs Qəddus) who supersede cenobitical monks in asceticism, miraculous power and sanctity. Hermits did not always seek complete separation from the cenobitical communities but frequently kept up relations with them; the hermitic way has been fully recognized as an honourable way of ascetic life, more difficult than the that in the community. E.g., in Waldəbba, a monk could become a hermit and be separated from the community only if the abbot decided that he was experienced enough and ready to continue the ascetic life alone. In order to become a hermit, a monk would not need to assume the scapular (on the contrary, hermits were supposed to reject a formal recognition of their spiritual merits). Having settled in a deserted place, a hermit would stay in complete isolation and seldom appear in the community. Some hermits never leave their abodes; however, they are sometimes helped by younger monks (GIRMA ElYAs 1977:110 113). In Ethiopia, hermitic life has always exercised an immense attraction, its followers being revered by both laymen and ecclesiastics (yet, they were sometimes at odds with representatives of the official Church hierarchy).

${ }^{27}$ Cp., e. g., RICCI 1969-1970:144-145; VAN DE WEYER 1973.

${ }^{28}$ On hamelat/meloto, which is considered to be the traditional clothing of both the monks and wandering students seeking for the education in church and monastic schools, s. Dillmann 1865:71, KWK 449. Cp. EAE I, 761-763: those monks who re- 
the assumption of the scapular (the highest grade of the monastic profession) though formally quite important, is implemented only in rare cases $^{29}$ — in spite of the fact that the service books provide a full set of relevant rituals, well known to, and much revered by, Ethiopian monks. It is possible that the early assumption of the scapular as described in many hagiographic works should be understood as a sign of the extraordinariness and sanctity of the vitas' protagonists (and be ascribed, thus, to the «imaginary world» of the hagiography): a saint need neither many years of ascetic exercises to reach the «angelic nature», nor should he wait many years for the scapular to be conferred upon him; ${ }^{30}$ even the period of probation and noviciate appears very short or even non-existent. As in the past, the institution of the «spiritual fatherhood» is also vivid today: the senior monk who initiates a novice into monastic life remains his «spiritual father» and actively participates in the «spiritual upbringing» of his «son» (while the latter maintains warm attitude to the former for many years), yet his advising concerns matters of spiritual life and is not binding, especially when his pupil matures and moves to another place.

ceived the sacerdotal consecration can carry hand-crosses, as priests do. In the sources one can find references to the lack of acknowleged standarts in monastic clothing, cp. the most valuable notes by Almeida, in: Historia Aethiopiae, ed. by C. Beccari, Roma 1907, book II, ch. XVIII, 195-200. There are also mentions of the yellow robes or cloaks worn by some monks (s. BECKInGHAM - HunTINGFORD 1961:126, 424), a custom preserved, e. g., in Waldəbba monasteries, and currently followed also by monks of Däbrä Libanos (Š̈wa) and some other communities. In the $20^{\text {th }}$ cent., there were some attempts at standardizing (and «modernizing») of the clothing of the ecclesiastics and monks.

${ }^{29}$ S., e. g., Ricci 1969-1970:144-145, Chaillot 2002:154-157.

${ }^{30}$ Quite the opposite to the living monastic tradition. According to the rules of Däbrä Abräntant, one of the monasteries of Waldəbba, a candidate for the scapular should be elected among old monks of the community. He must be renown for his piety, virtue, knowledge and other merits. He had to spend a long time living as a monk and being an example of perfect ascetisim (in particular, abstaining from meat and sleeping in a bed). Due to his age and way of life, he was expected to stay most of the time within his community; he could offer spiritual teaching, but he had to abstain from participation in any other active work, especially in administrative matters (BÄRIHUN KÄвBÄDÄ 1971:108-115). As local tradition reports, during the entire history of Waldəbba Abräntant only four monks have assumed the scapular (though honourable monks were numerous). The first was $14^{\text {th }}$-cent. Samu ${ }^{3}$ el of Waldəbba, who is considered to be the founder of Abräntant (the scapular was reportedly conferred upon him by Mädhaninä $\mathrm{Ggzi}^{j}$ in Däbrä Bänk ${ }^{\mathrm{w}}$ al; the Vita of Samu el, however, relates that he assumed from Mädhaninä $\exists g \mathrm{gi}^{\circ}$ the clothes [albas], the girdle [qənat] and the monastic cap [qob $b^{c}$, s. TuRAIEV 1902a:2), while the others were three prominent superiors of the community. Abba Gäbrä Ggzi ${ }^{\circ}$ abəher Täsämma was the last one to receive the scapular at Däbrä Dammo, in the late 1960s (BÄRIHUN KäBBÄDÄ 1971:109). 
Historically, the issues of strict distinction between the grades of monastic profession, the standartization of everyday monastic vestments and their distinction from the clothes of laymen, were certainly not a crucial point in Ethiopian monastic discourse; it is, however, quite natural that, regarding the question of garments, local Ethiopian tradition put emphasis on some other specific points. ${ }^{31}$ As to the hierarchy within the monasteries, this certainly existed in any Ethiopian cenobitical community, though its formalization (also by means of the parts of the monastic habit) may have happened only in a few cases - when it was required, e. g., by the growth of the monastery and by the need of organizing the religious and economical activities of a great number of monks. Ethiopia was famous for its numerous monasteries, but most of them, including the well-established and influential ones, had comparatively small communities. ${ }^{32}$ Däbrä Libanos of Šäwa, being among the few excep-

${ }^{31}$ While the Bible and extensive monastic literature (Mäșahəftä Mänäkosat) provided the religious, ascetic and ritual foundation for Ethiopian monasticism, the local tradition had a specific appearance. It is from this point of view that one should consider the notable remark by J. Simon concerning the so-called Ethiopic Regulae Pachomii (Dillmann 1866:57-69 [Hammerschmidt 1988]): "On ne peut citer aucun monastère éthiopien qui ait été organisé selon la "Règle de S. Pachôme"» (SIMON 1941 [HAMMERSCHMidT 1988]:301). While two of the three parts of these «Regulations», where a lot is said on the role of the monastic garb, were translated during the Axumite period (LUSINI 1997:54-55, n. 16-20), and the «Regulations» certainly exercised influence on the life in Ethiopian monasteries, attested collections of genuine Ethiopian monastic regulations are deeply rooted in the local reality and focus on quite different points (ibid. 55). Cp., e. g., the regulations (from the $15^{\text {th }} / 16^{\text {th }}$-cent. manuscript, compiled at an unknown monastery) containing a paragraph about the vestments expressing concerns different from the Regulae Pachomii (ibid. 57-60; «Ancora, il §2 contempla soltanto la pelle di capra come elemento specifico del vestito monastico, probabilmente per sottolineare come quello più degli altri sia l'autentico segno di riconoscimento del monaco», ibid., 58-59); cp. also concerns expressed in the «rules» of abba Nabyud (BEYLOT 1974:1, 16-17). Concerns of leaders of local communities should have focused on the simplicity of clothes, or avoidance of outspoken inequality among monks in this respect (e. g., as a repercussion of their different social background), or the amassing property by individuals, etc. Certainly, a substantial degree of disagreement between what is written/prescribed in the books and what is implemented in the real life is characteristic of the Ethiopian monastic tradition, as of any other (e. g., the Coptic monastic rite includes rituals for both the «little» and «great habits», but cp. EveTTs 1906:65: «Aujourd'hui les moines égyptiens ne portent que des tuniques noires et turban de même couleur sur une calotte, comme les prêtres séculiers»).

${ }^{32}$ It seems that the population of most monastic communities did not exceed a few dozens of brothers (like those noted by Alvares, s. BECKINGHAM - HunTingFord 1961:175, 185). Ethiopian sources hold witness to a few larger monastic communities; cp., a valuable description of the Ewosțatean monastic organization in Zär a Ya ${ }^{c}$ วqob's Mäṣhafä Borhan, which reports that in three nunneries affiliated to Däbrä 
tions, is reported to have had a population of no less than one hundred monks or many more over a long period of time. For the early $16^{\text {th }}$ cent. - shortly before the monastery was destroyed by Ahmad Grañ - there are some pieces of evidence that the community was hierarchically organised according to the monastic grades, and the bestowing rites for the parts of the monastic habit were established and duly performed..$^{33}$

\section{II}

There is no doubt that the value of the story's versions as presented in the hagiographic texts mentioned above is different for each of them. It is usually assumed that the hagiographers, more or less consciously, used their works for expressing their ideology and asserting the claims of their respective communities. However, one should not forget that this was just one - and possibly not even predominant — of the many functions at work in hagiographic texts. When compiling a new Vita, the hagiographer hardly distinguished those passages in the text which would serve as his monastic community's «credo» or «proclamation»; however, he maintained the same «literary devices» throughout the work. In addition to the passages he penned himself, the hagiographer used elements he borrowed, directly or indirectly, from both oral and written sources, which he could re-interpret and/or revise.

Bizän there were 1146 nuns (ConTI RossinI — RICCI 1965:150). This information, however, refers to the peak of the Ewostatean movement; the number of monks decreased in the early $16^{\text {th }}$ cent. (cp. BECKINGHAM - HuNTINGFORD 1961:88-90); currently there is no trace of a large monastic settlement there. There are some other reports on monastic settlements with hundreds and even thousands of monks (cp. GIRMA ElYAS 1977:101; BeCKingham - HunTingFord 1961:201). Even if these reports are trustworthy, big communities could not persist for long, since they would quickly exhaust the ecological resources of the region and would be vulnerable to epidemics and military conflicts (for the population in Byzantine monasteries, and approximate statistics comparable to the Ethiopian situation [notwithstanding the important cultural, social and economical differences!], s. Thomas — Constantinides Hero 2000, vol. 1, XVI-XVII).

${ }^{33}$ Almeida, in: Historia Aethiopiae, ed. by C. Beccari, Roma 1907, book II, ch. XVIII, 196-200. Almeida mentions those who assumed «the great habit» - the scapular; he also reports of an exceptionally lengthy probation period (7 years). A monk could assume the scapular only after he had assumed other parts of the habit (some assumed only the tunic first, and the monastic cap later), only if he reached the age of 30 years and fulfilled another period of probation. It seems that the community of Däbrä Libanos retains, to the great extent, the old organisation: it consists of probationers $\left(\operatorname{ard} a^{\circ} \partial t, \mathrm{sg} . r \ddot{a} d \partial^{\circ}\right)$ who are waiting for being accepted into the monastery, junior monks ( $n \partial^{\partial} u s a n$, sg. $n \partial^{\nu} u s$ ), senior monks ( $a^{c} \partial r u g$ ), and «perfect monks» (lit. «saints», qaddusan, sg. qəddus; s. ACDic IV, 142-156; for the term, s. also RicCI 1966:77 and 93, n. 174; RICCI 1969-70:145). 
Thus, understanding the message of a hagiographic account would mean, to a great extent, disentangling the process of its emergence, the task being distinct from, though parallel to, establishing the work's textual history within the framework of a critical edition. ${ }^{34}$ Let us therefore discuss each of the most important traditions that relate the story in question, in chronological order.

${ }^{34}$ Even though I have already expressed my view concerning the hagiographic tradition of the Vita of Täklä Haymanot on several occasions, I would like to summarize here the most crucial points. It is generally accepted that the hagiographic tradition of the Vita consits of four recensions. 1) The Synaxarion note on 24 Nähase, the day of Täklä Haymanot's death, is represented by at least two text-types: the old one (GuIDI 1912:377-383, the text from the MS «P»), and the more recent one (ibid. 1912:474476, «Appendice»; cp. Budge 1928:1241-46). 2) The Waldəbba recension, only preserved in two copies (one of them, MS éth. 136, from Bibliothèque nationale de France, dates possibly into the $15^{\text {th }}$ cent.) has the reign of Yəshaq (1414-1429) as its terminus post quem. It can not fully be excluded that this work does not date from an even earlier period, since King Yəshaq is not mentioned in the main body of the text, but in the «Miracles», which could be attached to the Vita somewhat later. 3) The best-known recension of the Vita is the Däbrä Libanos version (BUDGE 1906), compiled around 1515 by the initiative of əç̣çäge Pețros. This recension is represented by two text-types: the original one and its slightly reworked and much more recent variant (the first half of the $18^{\text {th }}$ cent.?; cp. Nosnitzyn 2000). 4) There is a number of definitively interrelated texts - their archetype remains to be reconstructed — which preceed the recension of Däbrä Libanos and were incorporated into it. The so-called Hayq recension (the critical edition of which I am currently preparing) owes its name to MS EMML 1834, a $16^{\text {th }}$-cent. Gädlä Qəddusan from Däbrä Hayq Gsțifanos, the hagiographic collection with the Acts of Täklä Haymanot differing from both the Waldəbba and Däbrä Libanos recensions (see Getatchew Haile's description of EMML 1834, 2134). MS EMML 8742, from Tana Qirqos (not catalogued, accessible only in the National Archives and Library of Ethiopia, Addis Ababa), contains a text of the same type as EMML 1834, though with substantial differences. EMML 1834 seems to represent an abridged version (typical for a work included into a collection of texts), with a few new passages (in some cases the influence of the Däbrä Libanos recension can not be exluded) of the same text as in MS Paris, Bibliothèque national de France, Éth. 342 = Griaule 38 (late 15 th cent., s. GrÉBAut 1941:18-20), to which $16^{\text {th }}$-cent. or older MS Ṭānāsee 162 = Dāgā Esțifanos 51 (SIX 1999:202-206) is identical. A suggestion concerning the dating of this text, designated as «the $1^{\text {st }}$ Däbrä Libanos recension», ca. 1425-1426, was made on the basis of Éth. 697, another text related to Éth. 342 (s. DERAT 1998:77; for the internal evidence pointing to a slightly more recent time, i. e. to the early reign of Zär ${ }^{3 a} Y^{c}{ }^{c}$ əqob, s. NosNitsin 2003:149, n. 40). The brief version of the Synaxarion recension of the Vita appears to be one of the oldest hagiographic documents about Täklä Haymanot and most probably antedates both the Hayq and the Däbrä Libanos recensions; this text was the basic source for the compiler of the Hayq recension (s. Nosnitsin 2006, forthcoming). After the Däbrä Libanos recension was composed, but before 1532, the Homilies on the annu- 
In Waldəbba recension of the Vita of Täklä Haymanot, the account of the Saint's visit to (Däbrä) Hayq is included in the sequence of events which took place when the saint was wandering in northern Ethiopia. According to this recension, Täklä Haymanot decided to adopt the «monkish yoke» (hC:0・音 : $\mathbf{q} \mathbf{3} \mathbf{i}(\boldsymbol{i} \boldsymbol{i})$ after he was consecrated priest and distinguished himself while converting the people into Christianity. Thus, Täklä Haymanot went to Angot and reached Lake Hayq ( $\boldsymbol{h}, \boldsymbol{\ell} \boldsymbol{\phi}: \mathbf{q} \boldsymbol{h} \boldsymbol{C})$, where he received the monastic

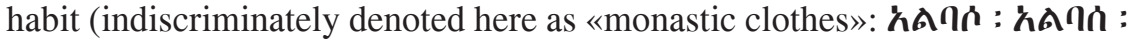

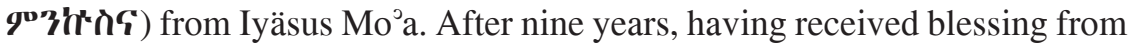
Iyäsus $\mathrm{Mo}^{\circ} \mathrm{a}$, he moved (6.nत) to Təgray and received the monastic cap and scapular at Däbrä Dammo (the name of the superior is not mentioned). The account states that in Təgray Täklä Haymanot introduced many people into

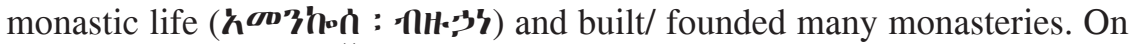
his way back to Sewa (Šäwa), Täklä Haymanot visited Hayq where the notorious conversation with Iyäsus $\mathrm{Mo}^{\circ}$ a took place. The superior asked his pupil what he had on his head; having learnt that this is the «perfect order» of the

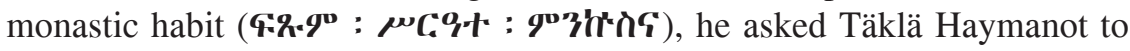
give him both the monastic cap and the scapular, and the latter fulfilled his teacher's request. ${ }^{35}$

The perception of the Waldəbba recension as the early stage in the development of the hagiographic legend of Täklä Haymanot (which may have been «only» 120-140 years apart from the events it described) is important for understanding the episode. The hagiographer did not try to adapt the account to any literary model, ${ }^{36}$ being perhaps not skilled or knowledgeable

al holidays of the Saint and three respective collections of the Miracles were attached to the Vita. «The Book of the Translation of the Body of Täklä Haymanot», which is usually found in the MSS with the Däbrä Libanos recension of the Vita, represents a still separate tradition (s. NosNitsin 2003).

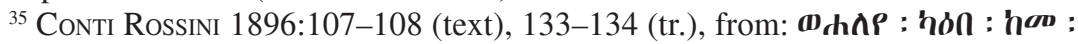

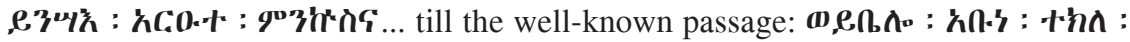
4,

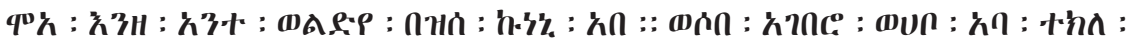
४,

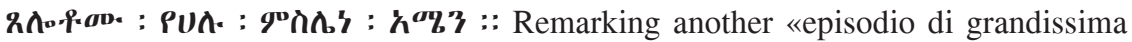
importanza», Conti Rossini (ibid., 133, n. 1) gives in the footnote, as elsewhere, the contents of the corresponding passage from Manuel de Almeida's resumé of the Däbrä Libanos recension of the Vita; for this purpose Conti Rossini used a copy of the work received through M. Esteves Pereira (ibid., 102; originating, most probably, from an MS of the National Library, Lisbon, cp. Esteves PereIRA 1899:6, n. 6).

${ }^{36}$ It can not be excluded, however, that the author «reversed»1 Par. 17:12 (the words God addressed to King David through the Prophet Natan) «I will be his father, and he shall be my son (and I will not take my mercy away from him...)», according

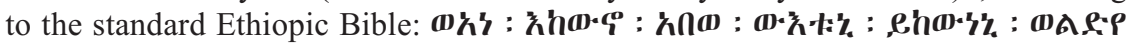
(cp. also 1 Par. 22:10). 
enough to put the narrative into a more elaborate literary shape, or simply having no intention to do so. Thus, in the Waldəbba recension the account has neither literary decorative elements nor, seemingly, ideological implications, and may have a direct link to the oral legend, as attested by the frank and somewhat naïve expression of astonishment and admiration in the words Iyäsus $\mathrm{Mo}^{\circ}$ a directed to his own pupil: «Oh my son! What is it on your head, and what is on your neck?!», and the following: «Give me the (thing) that is similar to what I see on your neck, for it is nice! ${ }^{37}$

The Synaxarion commemoration of Täklä Haymanot on 24 Nähase (in its «short version») differs from the Waldəbba recension of the Vita of the Saint. While reporting that Täklä Haymanot had only one spiritual teacher - Bäṣälotä Mika ${ }^{2}$ l of Amhara (s. above, n. 7), it does not mention whether Täklä Haymanot received from him any separate part of the monastic habit. ${ }^{38}$ This story was incorporated into the hagiographic legend of Täklä Haymanot as a stable element and appears in other recensions of the Vita, its variations being developed from the common narrative core: Täklä Haymanot stayed in the mona-

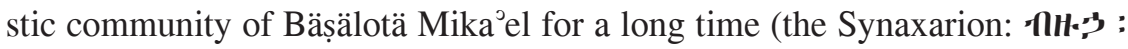

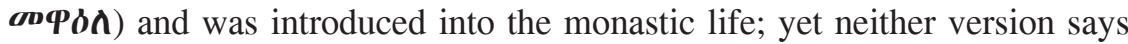
that he received there either monkish robe, or monastic cap and scapular. ${ }^{39}$

The Hayq $\left(/ \ll 1^{\text {st }}\right.$ Dabrä Libanos») recension as transmitted in MS Éth. 342 $=$ Griaule 38 and a few other manuscripts ${ }^{40}$ presents the story of Täklä Hay-

${ }^{37}$ One may get an impression of a somewhat «anecdotal» character of the account, which in this sense appears to be unique and differs from both hagiographic accounts and reality: it is hardly possible that monastic cap and scapular could be adopted in such a simplified way and without appropriate rituals (still another feature of an oral account?). Curiously, the account implicates that Täklä Haymanot was «deprived», in fact, of his monastic cap and scapular, which he had to give to his spiritual teacher. Most probably, in this case we should assume that, to a certain extent, this passage of the Waldəbba recension remains a mystery - we still have no proper understanding of the message conveyed in the episode. So far I have found no similar stories in other hagiographic sources that could facilitate the analysis.

${ }^{38}$ At the same time, the Synaxarion reports that, in Wägda, Täklä Haymanot

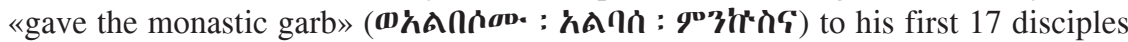
(GuIDI 1912:382).

${ }^{39}$ On the one hand, the reliability of this account is difficult to assess against what is said in the Waldəbba recension of the Vita (it looks a little unusual that a novice could spend a considerable number of years in the monastic community while receiving no part of the monastic habit; in fact, we can only speculate why in one case it is Iyäsus $\mathrm{Mo}^{\mathrm{J}} \mathrm{a}$, in another Bäșälotä Mika ${ }^{2} \mathrm{el}$ ); on the other hand, this «lacuna» inspired other hagiographers to «fill» it with different personalities — spiritual teachers - who overshadowed Bäșälotä Mikael (s. Nosnitsın 2006, forthcoming).

${ }^{40}$ Apart from MS Éth. 342 = Griaule 38, I was able to check MS Ṭānāsee $162=$ Dāgā Esțifanos 51; futhermore, MS Éth. 697 (s. French translation in DuCHESNEFouRnET 1908, vol. 1, 338-440), though recent $\left(18^{\text {th }} / 19^{\text {th }}\right.$ cent.?) and copied with omissions and mistakes, contains the same variant of the story. 
manot's stay at Däbrä Hayq Hsțifanos as a lengthy and detailed account containing much more information than the Waldəbba recension (the latter was obviously unknown to the author). Apparently following the Synaxarion note, the text reports that Täklä Haymanot entered the community of Bäșälotä Mika ${ }^{3}$ l (neither its name nor its location are designated), asking Bäsälotä

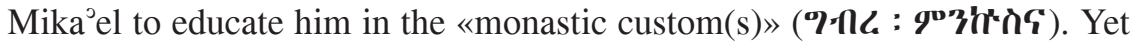
neither here nor further on does the text mention any separate part of the habit as symbols of the grades of monastic profession, though it does touch upon some topics related to regulations of monastic life. ${ }^{41}$ After a long stay with Bäșälotä Mika ${ }^{3}$ el, Täklä Haymanot proceeds to Däbrä Hayq Gsțifanos and remains there for 10 years, before returning to his native Säwa (Šäwa). In general, the text in MS Éth. 342 = Griaule 38 does not add anything special to the episode in question. ${ }^{42}$ The account is enriched with hagiographic «common places» on the endurance of the Saint in fasting and praying, his miraculous walking on the water, etc.

${ }^{41}$ The account about Täklä Haymanot's life in the monastery of Bäșälotä Mika ${ }^{2}$ l is lengthy (MS Éth. 342, fol. 89vb-97ra), very dynamic and full of developments. In the scene of the first conversation between Bäșälotä Mika ${ }^{2} e l$ and Täklä Haymanot, the hagiographer raises an important topic concerning the monastic discipline, namely, the move from one monastic community to another. Bäșälotä Mika ${ }^{0}$ l states that a monk should ask his superior (mamhor) for permission if he wants to leave his community and move to another one; otherwise the head of any other community

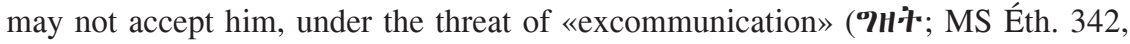
fol. 89vb-90rb). This statement certainly reflects the constant intention of the monastic elite to prevent the uncontrolled wandering of monks (cp. KAPLAN 1984:49); however, the request of Bäșälotä $\mathrm{Mika}^{2} \mathrm{el}$ as presented in the Hayq recension — to hear the words of Täklä Haymanot's mamhər confirm what Täklä Haymanot said — appears to be a literary device «repairing» the inconsistency of the legend concerning Täklä Haymanot's initial receiving of the monastic garb. Bäșälotä Mika ${ }^{\jmath} e l$ accepted Täklä Haymanot as «a monk from the country of Sewa» (the monk with whom Täklä Haymanot travelled was also convinced that he was a monk), though the latter has virtually not entered the monastic profession yet. However, Täklä Haymanot tells that it was his mämhər who sent him to Bäșälotä Mika ${ }^{3}$ l to learn the monastic life, while the Holy Spirit confirms his words. Though the language of the passage is somewhat ambiguous, it is clear that Täklä Haymanot virtually had no spiritual tea-

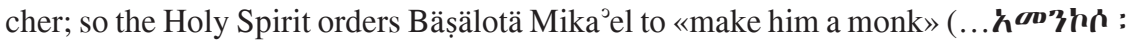

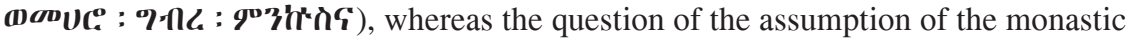
habit remains without clear answer.

${ }^{42}$ It only reports that Iyäsus $\mathrm{Mo}^{\circ}$ a received Täklä Haymanot well and offered him

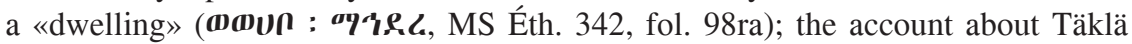
Haymanot's stay at Däbrä Hayq Gsțifanos is very brief (fol. 97rb-100va), its major portion being of a didactic treatise inspired by Mt. 25 (fol. 98ra-vb). Occasionally,

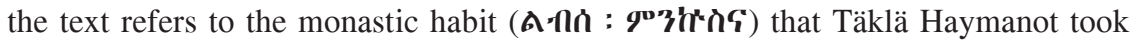
upon his nephew Marqos, «his brother, the son of his father's brother in the flesh»

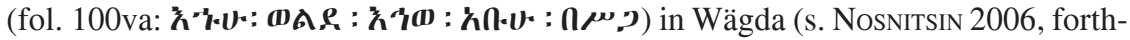


The text preserved in the $15^{\text {th }}$-cent. MS EMML 8742 from TTana Qirqos represents a source of particular value, unfolding a version of the story as possibly related and perceived in the $15^{\text {th }}$ cent. by the monks of Tana communities. According to MS EMML 8742, too, Täklä Haymanot spent a number of years at the place of Bäșälotä Mika ${ }^{3}$ el, without the formal assumption of the monastic habit. ${ }^{43}$ Thereafter, the angel told him to go to Däbrä Hayq Gsțifanos, where Iyäsus $\mathrm{Mo}^{\mathrm{J}} \mathrm{a}$ was supposed to vest him with «the monastic

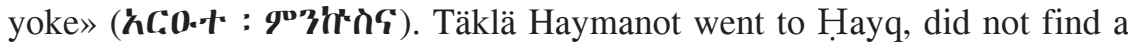
boat, and stood praying untill Archangel Michael appeared, walking on the surface of the water (fol. 35rb), and urging Täklä Haymanot to follow. ${ }^{44}$ Here, at Däbrä Hayq Usțifanos, Iyäsus Mo ${ }^{3}$ a vested Täklä Haymanot with the monastic garb, obviously completing the ritual of the monastic consecration. ${ }^{45}$ After some time, Täklä Haymanot decided to visit other monasteries, ${ }^{46}$ and,

coming). The absence of certain details concerning the «monastic career» of the Saint might have been later considered as an inconsistency, leading to attempts at «correcting» the legend: e.g., in recent MS Éth. 627, fol. 137, Täklä Haymanot is reported to have acquired the scapular from Bäșälotä Mika ${ }^{3}$ l.

${ }^{43}$ Täklä Haymanot is called by God «to adopt the monastic habit of the fathers»

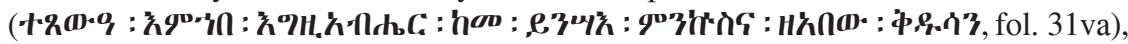
the name of the place he is supposed to go to is not indicated. When he comes to a monastery, he is accommodated by a monk. The following day, the abä monet of the place, $a b b a$ Bäșälotä Mika ${ }^{2}$ l, is informed about the new-comer and asks him to come

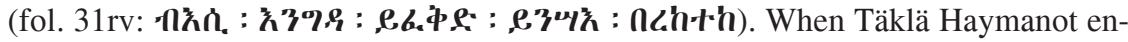
ters, Bäșälotä Mika ${ }^{0}$ l stands up, greets him and kisses his head (fol. 32ra ... wr; $\boldsymbol{\ell}$ :

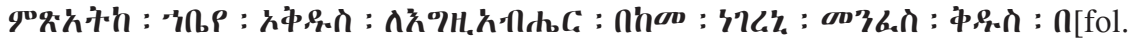

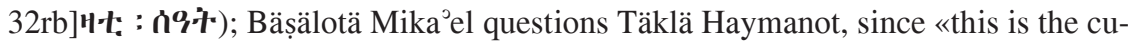

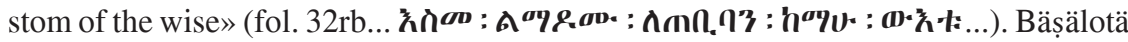
Mika ${ }^{2}$ l allows Täklä Haymanot to stay with him, yet nothing is said about the assumption of a monastic habit. Täklä Haymanot serves in the community doing every

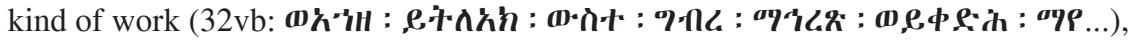
here the narration being interrupted by biblical quotations (Mt. 20:28; Phil. 2:3-9). Then the contendings of Täklä Haymanot are described (fol. 33rb-va), including him

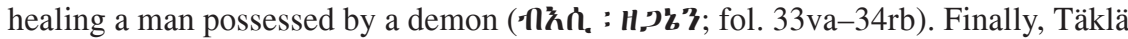
Haymanot is displeased by fame (fol. 34va).

44 Täklä Haymanot and Archangel Michael reach the church of the monastery; there follows a complex account on how Iyäsus Mo'a learnt about Täklä Haymanot's

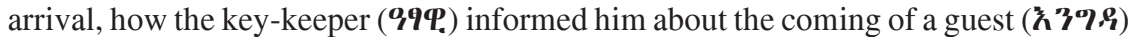
and let Täklä Haymanot enter (fol. 35va-36ra, s. below).

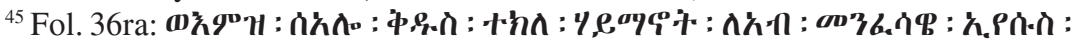

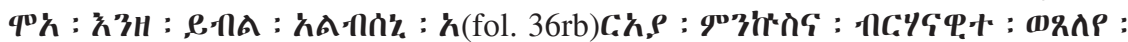

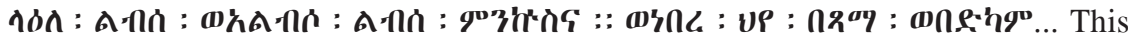
passage is followed by the description of Täklä Haymanot's ascetic life at Däbrä Hayq and his celestial travel to Paradise ('וֹ), where he saw the «mysteries» (fol. 36va-37ra).

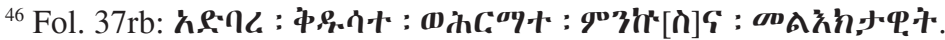


having crossed Lake Hayq by walking on the water once again, he went further and reached Däbrä Dammo. Here, at «the place of Arägawi», he took on the monastic cap and scapular, ${ }^{47}$ the name of the superior - Täklä Haymanot's spiritual father - not being mentioned. ${ }^{48}$ After the description of Täklä Haymanot's contendings at Däbrä Dammo and an extensive praise of him, there follows a note on Täklä Haymanot's travelling around Däbrä Dammo and back to Sewa (Šäwa), via Däbrä Hayq, ${ }^{49}$ and - the most important matter - the note concerning the parts of the monastic habit received by Iyäsus $\mathrm{Mo}^{\circ} \mathrm{a}$ from his spiritual son Täklä Haymanot, with a striking statement: «...And many of our elders told that our father Iyäsus $\mathrm{Mo}^{\circ} \mathrm{a}$ took the (monastic) cap and scapular from his (spiritual) son Täklä Haymanot». ${ }^{50}$ The passage on fol. 39va recalls the Waldəbba recension of the Vita; ${ }^{51}$ and it is

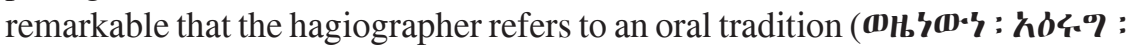
$\|(H \cdot ; 3) . .$.$) - not to the «old writings» — as to his source.$

The most remarkable thing is that the same version of the story is found in a copy of the work produced at Däbrä Hayq Jsțifanos - late $15^{\text {th }} /$ early $16^{\text {th }}$-cent. MS EMML 1834 - the text that gave name for the entire recen$\operatorname{sion}^{52}$. This text repeats the entire passage narrating the «monastic career» of Täklä Hamynanot as it appears in MS EMML 8742 (including what the «elders told» of Iyäsus Mo'a's assumption of the monastic cap and scapular). There are some differences which probably reveal the virtual considerations

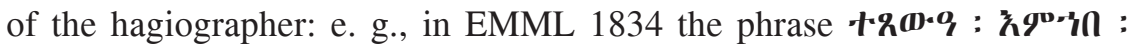

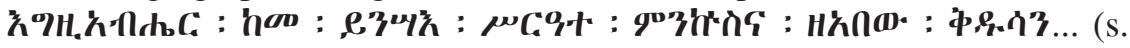
above, n. 43) appears before the account of Täklä Haymanot's stay at Hayq, in order to show that his «monastic career» developed in the proper way: according to the legend, indeed, Täklä Haymanot was formally initiated into monastic life at Däbrä Hayq, ${ }^{53}$ not in the community of Bäșälotä Mika ${ }^{3}$ l.

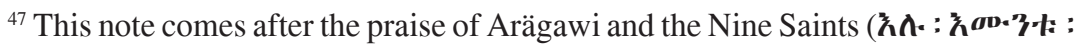

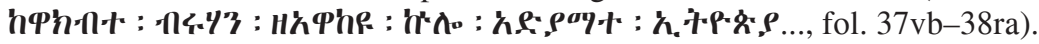

${ }^{48}$ Fol. 38ra: os

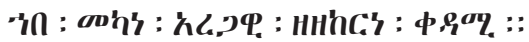

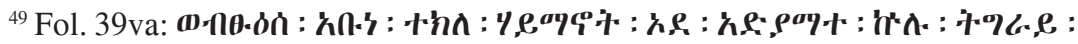

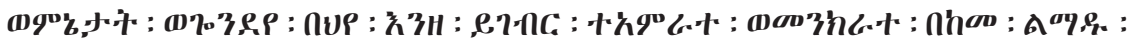

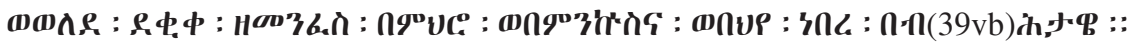

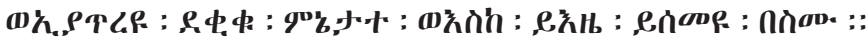

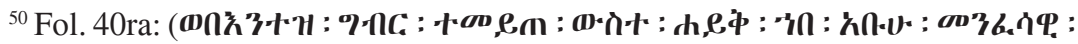

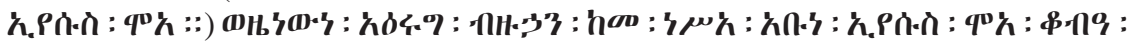
क乡กh.

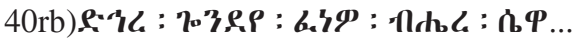

${ }^{51}$ Conti Rossini 1896:107-108 (text), 133-134 (tr.).

${ }^{52}$ S. EMML 1834, fol. 93rb-100rb; here fol. 100va.

${ }^{53}$ S. EMML 1834, fol. 99rb. 
Like EMML 8742, EMML 1834 refers to two spiritual fathers of the saint

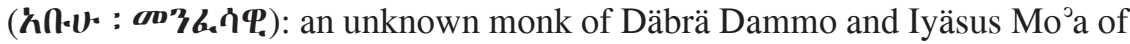
Däbrä Hayq. ${ }^{54}$

The question of how the hagiographic tradition explains the strange story of Täklä Haymanot giving the monastic cap and scapular to his spiritual father makes it necessary to examine the traditions of Däbrä Dammo. The Vita of Zä-Mika ${ }^{3}$ el Arägawi appears to be the most important source. ${ }^{55}$ The passage which is usually referred to in connection with the analyzed episode is not included in the description of the life of Zä-Mika ${ }^{3}$ el. It is found in a brief history of the community of Däbrä Dammo - attached to the biography of the Saint. In turn, this history is not a homogeneous text: it encompasses several different (predominantly historiographic) pieces, mostly following the sequence of the abbots of Däbrä Dammo - from Matyas to Zä-Iyäsus. The narration concerning the tenure of $a b b a$ Yohanni - the seventh after Zä-Mika ${ }^{2} \mathrm{el}$ - is composed of two notes. The first reports the construction of a church; the second refers to two prominent monastic leaders visiting Däbrä Hayq — Iyäsus $\mathrm{Mo}^{3} \mathrm{a}$ and Täklä Haymanot. ${ }^{56}$ The account obviously follows the chronology of events: Iyäsus $\mathrm{Mo}^{\circ}$ a came first, received the «scapular of

${ }^{54}$ S. EMML 8742, fol. 40ra; EMML 1834, fol. 100va.

${ }^{55}$ S. DEB 209-210 («Zä-Mika'èl 'Arägawi»); RAINERI in: EnSanti II, 1382; the Vita of Zä-Mika ${ }^{3}$ el Arägawi is supposed to have been written in the second half of the $15^{\text {th }}$ cent. (GuIDI 1932:60; RicCI 1969:825).

${ }^{56}$ After the description of the death of the Saint in the time of king Gäbrä Mäsqäl

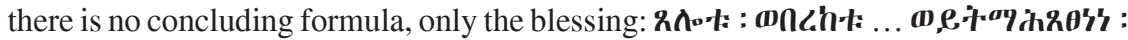

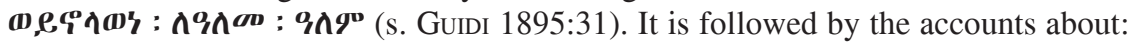
the tenure of Matyas, who is credited with having commissioned the writing of the Vita of Zä-Mika ${ }^{2}$ el and - along with Yosef — to have been the main informant about the life of Zä-Mika ${ }^{2}$ l (ibid. 31-32); the commemoration of the Saint, established by Matyas, with the miracle the multiplication of foods ( HWC:0 : n. $00 \cdot . .$. , ibid. 32); stories of the Saint's (posthumous) miracles related by the

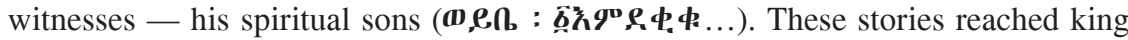
Gäbrä Mäsqäl, who bestowed upon the community the rich land possessions enume-

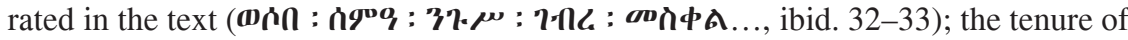

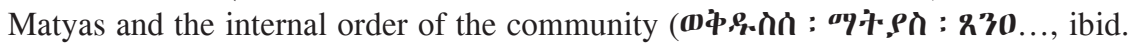
33-34). After Matyas's death, the account proceeds with brief mentions of Yosef and Mädhaninä $\exists \mathrm{gzi}^{\circ}$, the subsequent two abbots, and with an extensive story of the

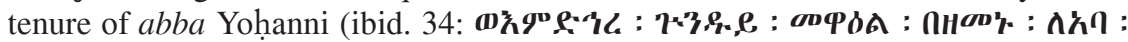
$\mathbf{P}^{\prime} \mathbf{h}^{\prime} \boldsymbol{c} . .$. ). The first tells of the construction of a church in a cave, intended as a burial place for monks; the second, more lengthy, relates the story in question. Thereafter, there is only a mention of abba Zä-Iyäsus who succeeded Yohanni, and a long and elaborate concluding formula (ibid. 35-36). I have checked quite a number of manuscripts containing the Vita of Zä-Mika ${ }^{2}$ el Arägawi, and in all of them the portion of the text described above reveals no substantial differences (apart from the usual variant readings). 
the monks» from $a b b a$ Yohanni and went to Hayq. Shortly after, Täklä Haymanot arrived from the place of Iyäsus $\mathrm{Mo}^{\circ} \mathrm{a}$ (sic!) and asked for the monastic cap and scapular. However, as he told of his intention to go to Jerusalem, Yohanni persuaded him to give up this idea. Täklä Haymanot received the monastic cap and scapular and, after several years at Däbrä Dammo (in Guidi's edition: 12 years), returned to Iyäsus $\mathrm{Mo}^{ } \mathrm{a}$. The account ends with the laudation of both Täklä Haymanot and Iyäsus $\mathrm{Mo}^{\circ} \mathrm{a}$. The hagiographer seems to be generally unbiased, and, at a first glance, has no other aim than preserving the memory of the two prominent monks in the annals of his monastery. ${ }^{57}$

${ }^{57}$ Here is the English translation of the Ethiopic passage (GuIDI 1895:34-35; the editor did not translate the passage into Italian, and limited the renarration to only a brief remark [ibid. 42]: «Abbâ Yohanî riveste dell'abito monacale Abbâ Iyasus Mo'a»...): «And thereafter $a b b a$ Iyäsus Mo ${ }^{` a}$ came and said to $a b b a$ Yohanni: 'Oh

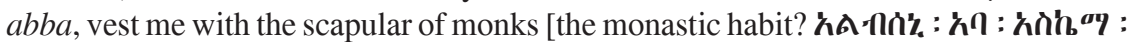

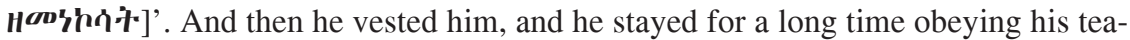
cher. And he learned the writing and became the one who loved solitude and prayer

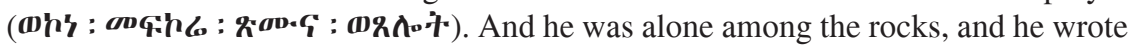
the (book of) Gospels there, which exists untill now. And he went and returned to a country whose name was Hayq, and he became the father of many monks there. And after a short time abba Täklä Haymanot came, having taken on the soldier's

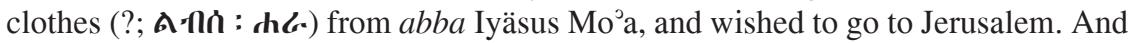
he reached the holy Däbrä Dammo where $a b b a$ Yohanni resided. As he saw him, he liked him and kissed him; and he told him about (the cause of) his coming, and he said to him: 'I came so that you would vest me with the monastic cap and scapular; I wish to go to the Sepulchre of our Lord'. And abba Yohanni said to him: 'I do not

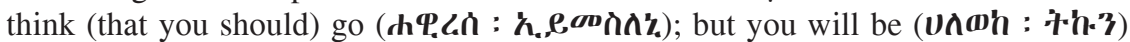

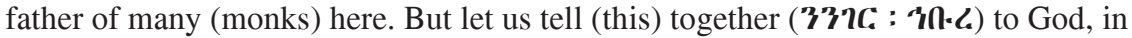
order that he will show us the good way'. And he gave him the scapular and monastic cap, and they stayed together, devoting themselves to praying. Our father Täklä Haymanot worked signs and miracles, and he was with $a b b a$ Yohanni for 12 years. He returned to Iyäsus $\mathrm{Mo}^{5}$ a having taken the scapular and monastic cap, for he had gone out of a desire of righteousness, loving the solitude and seclusion. They — Iyäsus $\mathrm{Mo}^{\circ} \mathrm{a}$ and $a b b a$ Täklä Haymanot — are wide in (their) branches, and they generated bright stars, as numerous as the sea sand, and they filled the land of the south $\left(\boldsymbol{q}^{\circ} \boldsymbol{P}^{\circ} \mathbf{C}\right.$ :

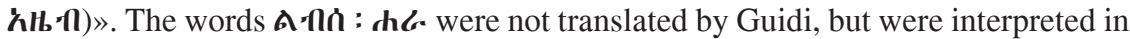
TADDESSE TAMRAT 1972:165 (followed by KAPLAN 1986:54) as: «dressed like a soldier». Indeed, harra in $\mathrm{G}^{\mathrm{c}}{ }^{\mathrm{z}} \mathrm{z}$ means «army, troops»; yet the hagiographer did not mean «soldier» in the proper (military) sense, but was probably referring to the Saint as «a soldier of Christ» (harawi zä-Krostos). However, as an alternative explanation one may suggest that the word harra might be connected with Arabic word harīr or Amharic harr 'silk' (s. LESLAU 1987:243), hence ləbsä harra may originally have the meaning «silk garb», i. e., «white cloth» referring to the monastic garb; about the Arabic loanwords in the Vita s. Guidi 1895:54). The Vita simply mentions that Täklä Haymanot came to Yohanni from Iyäsus $\mathrm{Mo}^{\circ} \mathrm{a}$, having received the monastic garb, but not yet the monastic cap and scapular. 
Surprisingly, the comparison of additional manuscripts of the Vita of ZäMika el Arägawi demonstrates that one of the most important passages is uncertain to such a degree that one should ask, who - Täklä Haymanot or Iyäsus $\mathrm{Mo}^{\circ} \mathrm{a}$ — «left without receiving the cap and scapular» ${ }^{58}$ Understand-

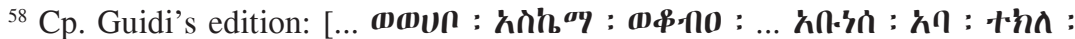
y,

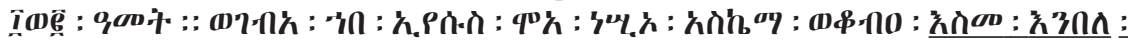

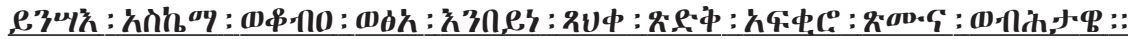

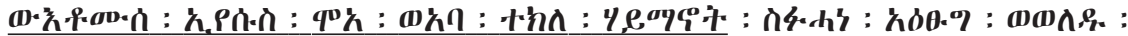

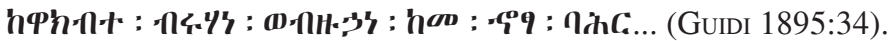

- Cp. a copy of the Vita of Zä-Mika ${ }^{2}$ el Arägawi from the monastic library of Däbrä Hayq, MS EMML 1953 (18 ${ }^{\text {th }}$ cent.; cp. SERgew Hable-Selassie 1992]):

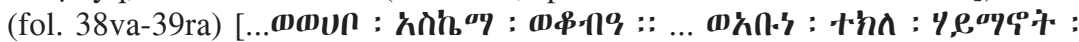

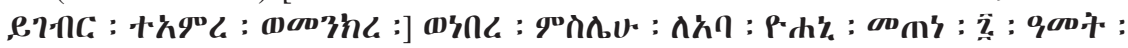

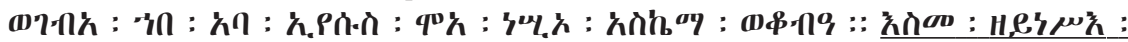

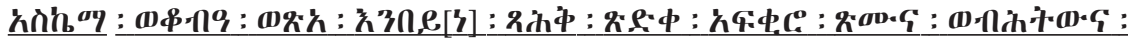

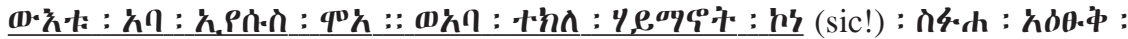

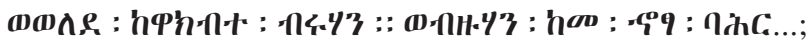

— Cp. MS EMML 1440 (17 $7^{\text {th }}$ cent., Gubalafto, Yäğğu, Wällo):

(fol. 57ra) [... कomun : hกh.

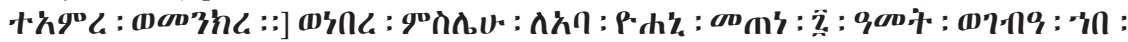

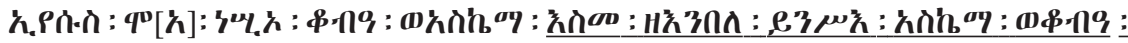

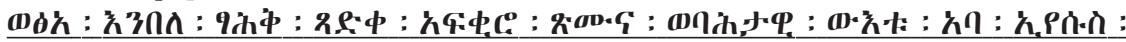

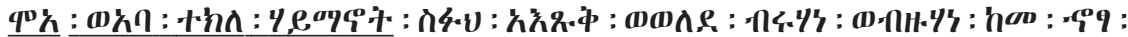
9hC:...;

- Cp. MS EMML 2795, $17^{\text {th }}-18^{\text {th }}$ cent., from the collection of Täsfa Haylu, obviously a member of the community of Däbrä Hayq (the manuscript is not registered in Sergew Hable-Selassie 1992):

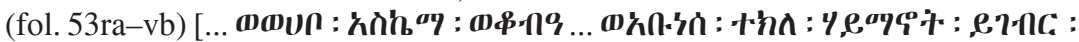

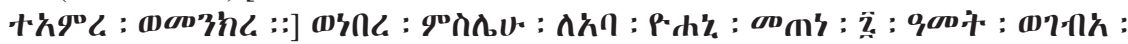

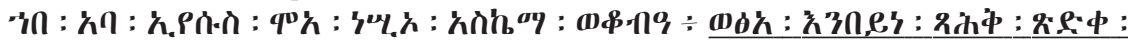

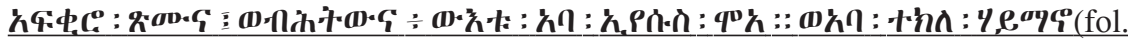

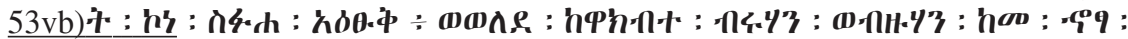
IAC:...;

— Cp. MS EMML 2504 (late 17 ${ }^{\text {th }}$ cent., Mițaq Amanu ${ }^{2} e l$, Tägulät-Bulga, Šäwa):

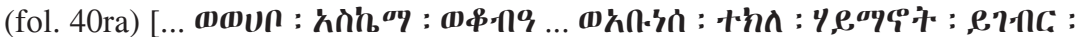

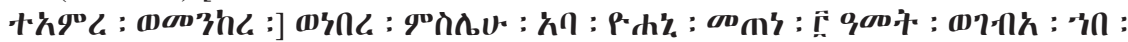
久 : :

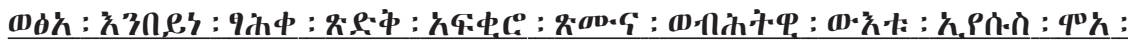

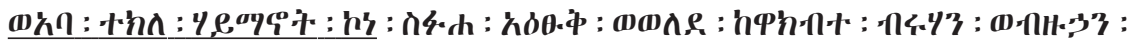

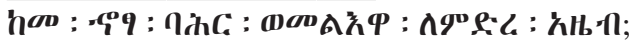

— Cp. MS Ṭānāsee 164 = Dāgā Esțifānos 53 (18 ${ }^{\text {th }}$ cent., s. SIX 1999:207-211; s. below):

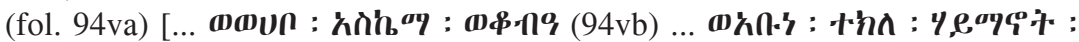

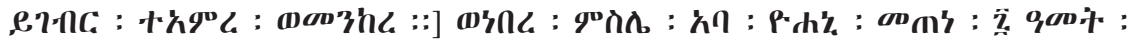

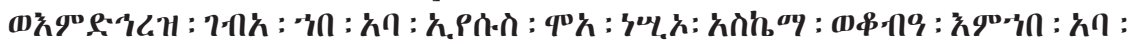


ing that the text of the Vita of Zä-Mika ${ }^{3}$ el Arägawi should be established in a new critical edition, I assume nevertheless that the short eulogy concluding the account originally contained the name of $a b b a$ Täklä Haymanot only; therefore, the phrase «...for, not having received the cap and scapular, he left seeking righteousness, desiring silence and solitude...» originally referred to Täklä Haymanot, whereas the name of Iyäsus $\mathrm{Mo}{ }^{3}$ a was added at a later point. ${ }^{59}$

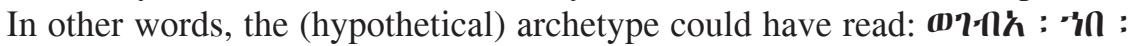

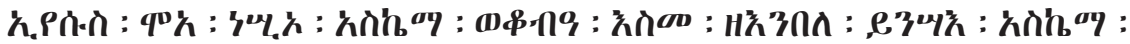

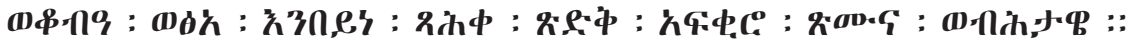

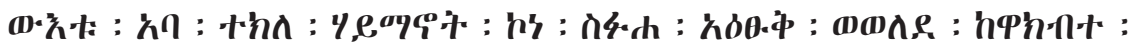

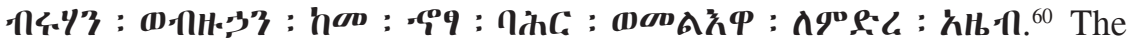
inclusion of the name of Iyäsus $\mathrm{Mo}^{\circ} \mathrm{a}$ into this passage could have led to its gradual re-interpretation with harmonisation of the grammatical forms up to the thorough usage of the plural ones (as in the text presented by I. Guidi):

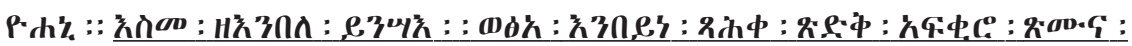

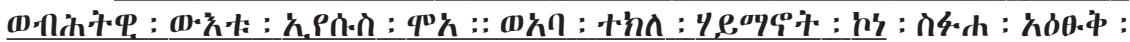

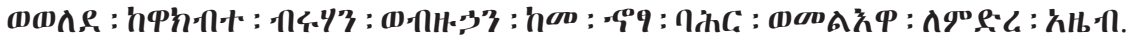

In the introduction to the edition I. Guidi states that the text of the Vita has been established on the basis of three manuscripts: 1) British Museum Add. 16,228 (DiLlMANN 1847:50, no. 46, not dated) = L1; 2) Orient. 709 (WRIGHT 1877:188, no. 285, «first half of the XVIII cent».) = L2; 3) Museo Borgiano L. V, 12 (missing for many years, s. Grebaut - Tisserant 1935:828) = R1. Additionally, the fourth one - 4) Museo Borgiano, L. V, 13 ( ibid. 826-828, no. 22) = R2, dated to 1559 г. — presents

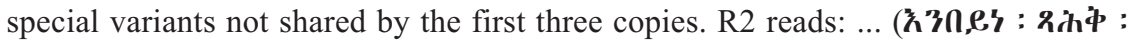

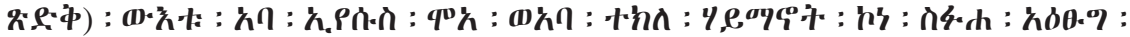

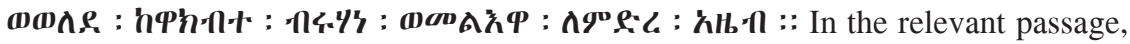
I. Guidi (Guidi 1895:35, s. above) probably followed mauscript L. V, $12=$ R1 (today missing!) which gives grammatically correct text, whereas the variants in the remaining three manuscripts are similar to those indicated above: they have, e.g., $\boldsymbol{\sigma} \cdot \boldsymbol{\hbar} \cdot \mathbf{1}$,

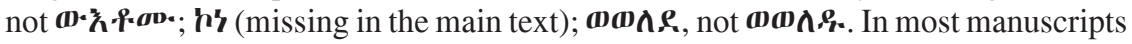
the period of Täklä Haymanot's stay at Däbrä Dammo is reported to have been 7 years, but in all the copies used by Guidi - 12 years (as in the Däbrä Libanos recension of the Vita of Täklä Haymanot, s. n. 6, above).

${ }^{59}$ If the original sentence had two subjects connected by a particle, all the forms would preferably have taken the plural (cp. Dillmann 1907:501-502); there would have been no reason for divergent readings.

${ }^{60} \ll \mathrm{He}$ returned to Iyäsus $\mathrm{Mo}^{3} \mathrm{a}$ having taken the scapular and monastic cap

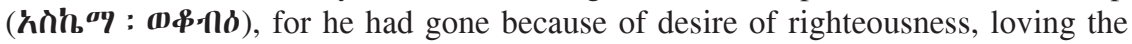
solitude and seclusion. He, abba Täklä Haymanot, became wide in (his) branches, and he generated bright stars as numerous as the sea sand, and they filled the land of the south». In the Waldəbba recension of the Vita of Täklä Haymanot, the metaphor «wide in (his) branches» refers to Täklä Haymanot, while mədrä azeb (lit. 'the land of the south', cp. nəgəśtä azeb from Mt. 12:42) may refer to the historical southern part of Ethiopia, i. e. Šäwa, the region thought to have been the place of Täklä Haymanot's major activities. 


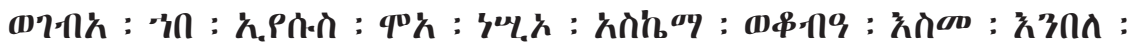

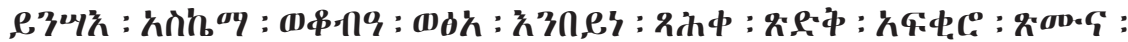

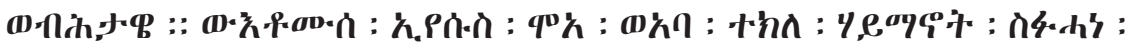

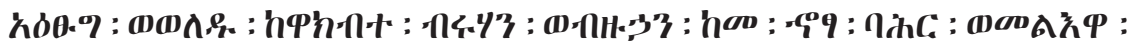

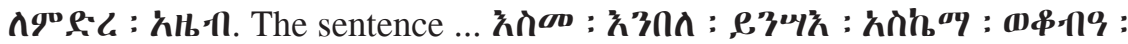

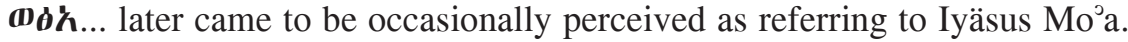
However, there is another account found in the manuscripts of the Vita of ZäMika ${ }^{\circ}$ el only a page before this one, relating, in clear terms (and in keeping with the hypothetical reading), that Iyäsus $\mathrm{Mo}^{\circ}$ a received the scapular from $a b b a$ Yohanni, and disrupting the entire construal of Täklä Haymanot giving the monastic cap and scapular to his spiritual father. ${ }^{61}$ The manuscript tradition of the Vita of Zä-Mika el currently counts more than 15 testimonia, but it is difficult to answer such questions as: 1) whether the historiographic notes were composed together with the Vita or added some time thereafter; ${ }^{62} 2$ ) at what time the contradictory reading emerged. In any case, it is clear that, in the $16^{\text {th }}$ cent., anyone reading the Vita could have had two interpretations of the episode in question.

From what has been said, it is not difficult to presume that in the Däbrä Libanos recension of the Vita of Täklä Haymanot the corresponding account about Täklä Haymanot acquiring the grades of the monastic profession emerged as a synthesis of several earlier hagiographic traditions. The origin of the different elements, however, can not be always established, since by the beginning of the $16^{\text {th }}$ cent. they must have been included in «common version(s)» of the legend of Täklä Haymanot — the famous Saint, — circulating along with the written traditions of his Vita. Yet, it is certain that the author of the Däbrä Libanos recension shaped his narrative following, more or less, the structure of the account according to the Hayq recension and used extensively its text(s), while extracting less voluminous but important details from another — Waldəbba — recension of the Vita.

The narrative structure of the account about the Saint's wanderings ${ }^{63}$ is symmetrical: Täklä Haymanot departs from and returns to Däbrä Hayq Hsți-

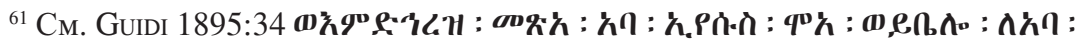

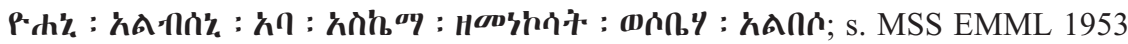
fol. 38ra-rb; 1440 fol. 56va-vb; 2795 fol. 51vb; 2504 fol. 40rb-va. In fact, TADDESSE TAMrat 1972:165 and n. 4 refers to this contradiction as well, though his remark on the «uncertainty of language» does not fully expose the problem of the passage.

${ }^{62}$ I think, it was most probably the case, though we have no single manuscript with the Vita alone (the information about an old manuscript of the Vita dated before 1425, which is preserved in Däbrä Dammo [MatTHEws — MoRdini 1949:49], can not be confirmed). A similar example can be found, e. g., in the Vita of Täklä Haymanot in the Waldəbba recension, where the Vita and the attached notes differently describe one and the same event - the funeral of Täklä Haymanot.

${ }^{63}$ Budge 1906, chs. 76-87. 
fanos; before returning to Däbrä Hayq he goes to Däbrä Dammo, departs from there and returns there. ${ }^{64}$ Täklä Haymanot leaves Däbrä Hayq Isțifanos seeking to receive the monastic cap and scapular, having been requested by Iyäsus $\mathrm{Mo}^{5}$ a to also bring the cap and scapular to him. ${ }^{65}$ In Däbrä Dammo he receives the cap and scapular from $a b b a$ Yohanni ${ }^{66}$ then he proceeds to other monasteries receiving blessings from other monks, and after three pilgrimages to Jerusalem he returns to Däbrä Dammo again. ${ }^{67}$ The sequence of the episodes is concluded with Täklä Haymanot's second coming to Däbrä Hayq Isțifanos and his handing over of the monastic cap and scapular to Iyäsus $\mathrm{Mo}^{\circ} \mathrm{a}$. In the Däbrä Libanos recension, when asking Täklä Haymanot to give him the monastic cap and scapular, Iyäsus $\mathrm{Mo}^{\circ}$ a expresses the essence of his request by means of the sentence found, in the same function, in the Waldəbba recension (the sentence was incorporated in the corresponding

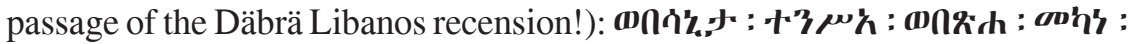
h, q"\% :

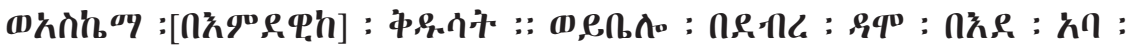

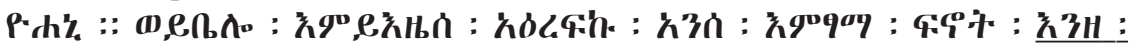

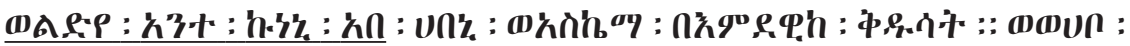
k : *hn : Y, H,en.กh. ${ }^{68}$

The episode in its entirety appears neither in the short version of the Täklä Haymanot's commemorative reading in the Synaxarion nor in the Hayq recension-related texts of the Saint's Vita. A remarkable chronological element, not attested in the earlier versions of the story, is the inclusion of $a b b a$ Yohanni, during whose tenure Täklä Haymanot, then, came to Däbrä Dammo - certainly a result of the influence of the hagiographical tradition of Zä-Mika ${ }^{2} \mathrm{el}$

${ }^{64}$ [Šäwa] — Däbrä Hayq — Däbrä Dammo — pilgrimages — Däbrä Dammo — Däbrä Hayq — [Šäwa].

${ }^{65}$ Budge 1906, ch. 77: indeed, here the hagiographer anticipates the kind of relationship that will come to existence if Iyäsus $\mathrm{Mo}^{\circ}$ a receives the parts of monastic habit — the monastic cap and askema - from his spiritual son, consequently, the essential passage from the Waldəbba recension (s. below) is echoed here: $\boldsymbol{\Phi} \boldsymbol{\Lambda}^{\boldsymbol{\sigma}} \boldsymbol{\eta}, \boldsymbol{\varphi}$ :

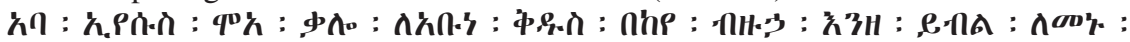

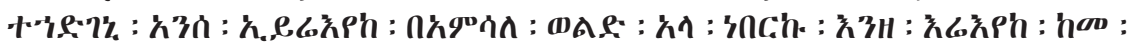

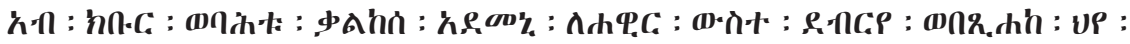

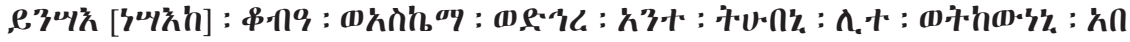
(for the translation, s. n. 10, above; it was E. Cerulli who signalled that the phrase

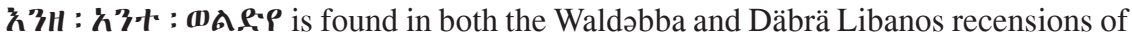
the Vita of Täklä Haymanot, KUR 1965:VIII-IX, n. 29).

${ }^{66}$ Budge 1906, ch. 78 (s. n. 11, above).

${ }^{67}$ Budge 1906, ch. 86.

${ }^{68}$ Budge 1906, ch. 87 (s. also n. 12, above). 
Arägawi ${ }^{69}$ It is noticeble that the author of the Däbrä Libanos recension chose (from the Vita of Zä-Mika ${ }^{2}$ el Arägawi?) one particular version of the story, yet it is not certain that the episode of that recension was supposed to demonstrate in any way Täklä Haymanot's superiority over Iyäsus Mo ${ }^{\circ} a$. This interpretation can not be excluded, but the primary goal of the hagiographer was most probably the «historical reconstruction» of the episode on the basis of (all) the pieces, scattered in different traditions, included into a coherent and complete account of the Saint's wandering; this account tells the story which, in fact, is not quite different from the one in MS EMML 1834. One should not assume that the primary aim of the author was to refer to the contemporary situation of his monastery and its relations with Däbrä Hayq Esțifanos, or to express any kind of ideological program or claims. In addition, in order to understand the limitations of any direct interpretation in this case, one should consider other episodes from the Vita of Täklä Haymanot, as well as accounts from other hagiographies; despite the turbulent religious history of Ethiopia, and the very intensive production of hagiographic works, the topos of the assumption of the parts of the monastic habit (as well as that of spiritual fathership) does not seem to have been overexploited.

The hagiographic tradition known as the Vita of Iyäsus $\mathrm{Mo}^{\circ} \mathrm{a}$ - the document which has attracted much attention in recent years - raises even more complicated questions. ${ }^{70}$ Some time ago the so-called «Homily [in honour]

${ }^{69}$ This relationship should be emphasized (cp. already TADDESSE TAMRAT 1972:166). There are some narrative elements shared by both texts. 1) As in the Vita of ZäMika ${ }^{3}$ el Arägawi, the Däbrä Libanos recension reports that Täklä Haymanot spent 12 years at Däbrä Dammo. 2) the Vita of Zä-Mika ${ }^{2}$ l Arägawi might have also been the source for the account of Täklä Haymanot's pilgrimage to Jerusalem. Even though the former reports that $a b b a$ Yohanni persuaded Täklä Haymanot to leave the idea of the pilgrimage to the Holy City, the Däbrä Libanos recension transformed the topic into a «positive account» and reports of the Saint's three visits to the holy city (beside the fact that the pilgrimage to Jerusalem is one of the most common motifs of Ethiopian hagiography). 3) The Vita of Zä-Mika ${ }^{2}$ el Arägawi might account for the unusual situation: how it happened that Iyäsus $\mathrm{Mo}^{\circ} \mathrm{a}$, though having stayed at Däbrä Dammo, did not receive the scapular (according to the Däbrä Libanos recension, he did not receive either the monastic cap or scapular) and, afterwards, had to ask his disciple Täklä Haymanot to bring him these parts of the monastic habit.

${ }^{70}$ In fact, among the sources discussed in this article, the Vita of Iyäsus Mo ${ }^{\circ}$ a was the latest to have been studied and published (s. E. Cerulli, in KuR 1965, also for the sources of the work, the rivalry between the monasteries and its possible historical context; for the substitution of Iyäsus $\mathrm{Mo}^{\circ}$ a through Täklä Haymanot in the legend about the re-establishment of the Solomonic dynasty, and the aforementioned polemical passage in the Vita of Iyäsus $\mathrm{Mo}^{\circ} \mathrm{a}$ ). This was compensated by the fact, that the hagiography of Iyäsus $\mathrm{Mo}^{\circ} \mathrm{a}$ has attracted considerable attention in recent years: s. Marrassini 1986; Tedeschi 1994; ID. in: EnSanti II, 267-271; Kropp 1998, 2003; HIRSCH 2003. 
of Iyäsus $\mathrm{Mo}^{\circ} \mathrm{a} »$ came to light, in which the biography and contending of this Saint are depicted in a different way from the Vita ${ }^{71}$. The dating of the composition of the Vita of Iyäsus $\mathrm{Mo}^{\mathrm{D}} \mathrm{a}$ to the period between the second half of the $15^{\text {th }}$ cent. and the beginning of the $16^{\text {th }}$ cent. ${ }^{72}$ seems to have been abandoned. Currently, the Homily, not the Vita, has been largely seen as the earlier stage in the development of the hagiographic tradition of Iyäsus $\mathrm{Mo}^{\circ} \mathrm{a}$, both works having different literary features and functions. ${ }^{73}$ The Vita ap-

71 The value of this text has been fully recognized only in the recent years: s. TedEsCHI 1994, with a fine analysis of the Vita but with the Homily largely discarded; the same in Sergew Hable-Selassie 1992; cp. also Tedeschi in: EnSanti II, 267271; BAUM, in: $B B K X X, 804-806$. In the latter publication the Homily is mentioned, yet the biography of the Saint is presented without differentiation of the sources or references to the origin of the details; cp., e. g., one «common place»: «Als Junge wanderte er nach Tigre und trat in das Kloster Debre Damo ein, wo er unter Abba Yohannis zum Kalligraphen und Theologen ausgebildet wurde». At the same time, the author states: «Das Gadl des Heiligen (EMML 1940) wurde nach 1601 aus älteren Quellen wie z.B. einer Homilie auf den Heiligen (dersan) und Motiven aus den Erzählkreisen über die Anfänge der Salomoniden zusammengestellt».

${ }^{72}$ E. Cerulli points to the second half of the $15^{\text {th }}$ cent. (CERULLI 1961:95). In the preface to the translation of the text, he considers the Vita «la rédaction composite» and states: «les Actes de Iyasus Mo’a ici édités ont été rédigés dans leur forme actuelle dans la deuxième moitié du XVe siècle» (KUR 1965:XIV-XV). Yet some arguments supposed to foster this hypothesis (ibid. IV-V, XV) appear today less convincing: e. g., «style 'fleuri' des introductions» is not a feature of $15^{\text {th }}$-cent. literary works alone; in the case of Dorsanä Ura ${ }^{\circ} l$ one should remember that the recension which is referred to was composed in the $19^{\text {th }}$ cent. (in the library of Däbrä Hayq Jsțifanos there are both the brief and the lengthy recension of this text, s. MS EMML 1942) etc. Cerulli stresses: «la question ... des rapports entre Iyasus Mo'a et Takla Hāymānot qui ne s'expliqueraient qu'en se référant à la période où l'hégémonie sur le clergé régulier éthiopien était à peine passée ou sur le point de passer du monastère de St Étienne de Hayq à celui de Dabra Libānos...» (KuR 1965:Xv).

${ }^{73}$ Against the cautious point of view expressed by MARRASSINI 1986:177, critisizing the proposal of Getatchew Haile in his comments to MS EMML 1960. The problem of the relationship between the Vita and the Homily was mostly dealt with by M. Kropp, who came to the conclusion that the terminus post quem for the Vita of Iyäsus $\mathrm{Mo}^{\circ}$ a should be «Ende des 15./Anfang des 16. Jhdts» (KROPP 1998:306); in his more recent publication, Kropp concludes, regarding in particular MS EMML 1960, that «der Textzeuge des dersan älter ist (Anfang 15. Jhdt.?), und der Text selbst aus noch früherer Zeit stammen kann» (KROPP 2003:194); the question of the time of the composition of the Vita remains without a clear answer (yet it is supposed to have been an instrument acting as a response to the spreading legend of Täklä Haymanot; ibid., 195). Recently, M.-L. Derat has summarized existing views, yet she cautiously accepted the old chronology and considers the Vita of Iyäsus $\mathrm{Mo}^{\circ} \mathrm{a}$ to have been created prior to that of Täklä Haymanot in the Däbrä Libanos recension («la fin du XVe siècle»: Derat 2003:88-90, 107, 109, 118 and elsewhere). 
pears to have been composed on the basis of the Homily by means of the revision and insertion of new pieces, including the well-known «testaments» between Iyäsus $\mathrm{Mo}^{0} \mathrm{a}$ and king Yəkunno Amlak. ${ }^{74}$ Consequently, the Vita of Iyäsus $\mathrm{Mo}^{\circ}$ a can be characterized, at first glance, as a hagiographic compilation - belonging to the same type of hagiographic composition as the Vita of Täklä Haymanot in the Däbrä Libanos recension.

As to the origin and structure of the passages concerning the relationship between Täklä Haymanot and Iyäsus $\mathrm{Mo}^{\circ} \mathrm{a}$, the Vita of the latter has the topic developed in three separate and complicated accounts:

1) Two parts of different origin can be distinguished in the first account. The first is clearly based on a fragment taken almost verbatim from the Homily with the only difference being that in the Homily Iyäsus $\mathrm{Mo}^{3}$ a receives from $a b b a$ Yohanni both the scapular and the girdle, whereas in the Vita the monastic garb (clothes) and girdle. ${ }^{75}$ The theme of the parts of the monastic habit is only further developed in the Vita; the second part of the account, in which, following his «monastic carrier», Iyäsus $\mathrm{Mo}^{\circ}$ a receives the scapular and monastic cap, is based on a rather faithful borrowing from the Acts of Zä-Mika ${ }^{2}$ l Arägawi. ${ }^{76}$

74 Thus, the Homily has been extended by numerous decorative literary elements and the «second narrative circle» (s. KROPP 1998:306-308).

${ }^{75}$ In the Homily, the account of Iyäsus Mo ${ }^{3}$ a's assumption of the monastic habit from $a b b a$ Yohanni appears after the following episodes, which, in fact, do not differ much from what is recounted in the Vita: Iyäsus $\mathrm{Mo}^{\circ}$ a leaves the worldly life, together with pious Yəmșa ${ }^{\circ}$ Məh̆rät, following the order of Archangel Gabri ${ }^{\circ}$ el (MS EMML 1960, fol. 31va-33va; KuR 1965, 8-9:25); he comes to abbot Yohanni and is introduced into the community (fol. 33va-rb; KUR 1965, 9:25-10:10); as Iyäsus $\mathrm{Mo}^{{ } \mathrm{a}}$ was dispatched to a travelling, he met robbers were nearly to kill him (fol. 33rb-34rb, KUR 1965, 10:10-10:25); Iyäsus Mo ${ }^{3}$ a punishes a rich man who has refused to let the Saint sleep in his house (fol. 34rb-35vb; KuR 1965, 10:25-13:2); Iyäsus Mo ${ }^{3}$ a stays (at Däbrä Dammo) for seven year humbly completing his pious works (fol. $35 \mathrm{vb}$ 36ra; KUR 1965, 13:2-14:5). After he carries out one extremely difficult task received from Yohanni, the latter brings him into the church, reads a prayer and, accor-

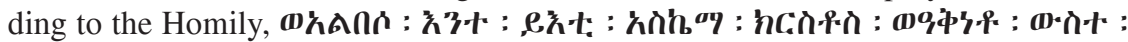

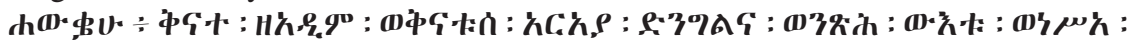

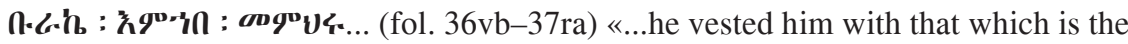
scapular of Christ [/the habit of Christ], and he girded his loins with the nice girdle, and this girdle is the likeness of the chastity and purity; and he [Iyäsus $\mathrm{Mo}^{\circ} \mathrm{a}$ ] received the blessing from his teacher»; the Vita has a slight, yet important change: instead of «the scapular», it has «monastic clothes/habit»: hАก :

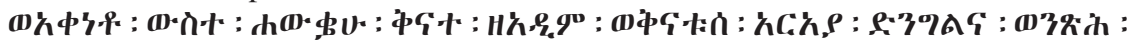
(D) 玄・1: (KUR 1965, 15:2-4).

${ }^{76}$ After the accounts of miracles that happen to Iyäsus $\mathrm{Mo}^{5} \mathrm{a}$ while in Däbrä Dammo (fol. 37ra-38rb; cp. KuR 1965, 15:4-17:24), there follows - in the Vita only the story of the foundation of Däbrä Hayq, the legend of the dragon (KUR 1965, 
2) In the second account, which is missing in the Homily, there appears $a b b a$ Täklä Haymanot. The account begins with a short traditional history of the Ethiopian monastic movement, exposed, apparently, from the point of view of the community of Däbrä Dammo, with the list of regions where Iyäsus Mo ${ }^{\circ}$ 's spiritual children preached and founded monasteries. ${ }^{77}$ After a mention of the «testament» between Iyäsus $\mathrm{Mo}^{\circ} \mathrm{a}$ and king Yəkunno Amlak, in accordance with which the title of ${ }^{c}$ aqqabe sä $\ddot{a}^{c}$ at was given to the abbot of Däbrä Hayq Hsțifanos, the hagiographer describes the pious life that Iyäsus $\mathrm{Mo}^{3} \mathrm{a}$ lead in his monastery ${ }^{78}$ and then proceeds with a lengthy account concerning abba Täklä Haymanot which appears to be comprised of three parts:

I. Täklä Haymanot arrives at Däbrä Hayq Jsțifanos, he assumes the monastic yoke and takes on the tunic, girdle and monastic cap from Iyäsus $\mathrm{Mo}^{\circ} \mathrm{a}$. He stays at Däbrä Hayq Hsțifanos for 10 years -7 years before and 3 years after the assumption of the monastic habit, the numbers, most probably, brought in accordance with the Däbrä Libanos recension of the Acts of Täklä Haymanot; 79

II. This lengthy part relating how Täklä Haymanot received the scapular is composed of several episodes. ${ }^{80}$ The Vita of Iyäsus $\mathrm{Mo}^{ } \mathrm{a}$ narrates Täklä Haymanot's departure to Däbrä Dammo and his stay with $a b b a$ Yohanni (following, in general, the outline of Täklä Haymanot's legend). The Vita reports that Täklä Haymanot wanted to go to his country (UกP : กAก- :

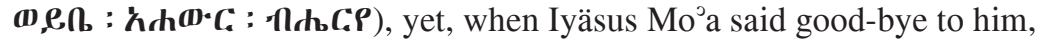
Täklä Haymanot headed in the opposite direction, to the north — to $a b b a$

17:25-19), the story of $a b b a$ Yohanni (ibid. 20), a notice on Gäbrä Ṣəyon, Iyäsus $\mathrm{Mo}^{\mathrm{j}} \mathrm{a}$ 's brother who has entered «another monastery» and dies on the $25^{\text {th }}$ of Yäkkatit (ibid. 20:21-21:6). The next account (about the construction of a church «in the entrance of [Yohanni's] cave», ibid. 21:6-21:13) is the same - with the exception of some slight changes — as in the Vita of Zä-Mika ${ }^{3}$ el Arägawi (Guidi 1895:34,

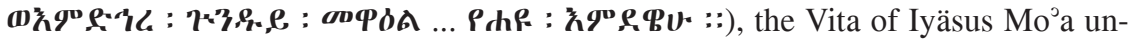
doubtedly being the recipient text; the same is also valid for KuR 1965, 21:13-19

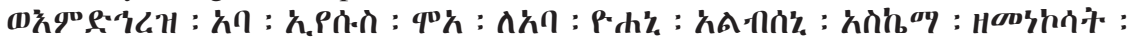

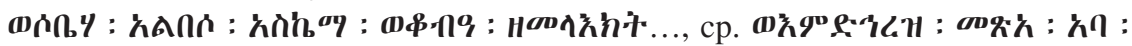

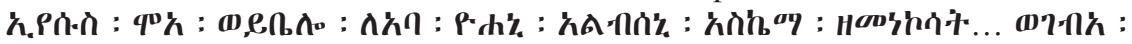

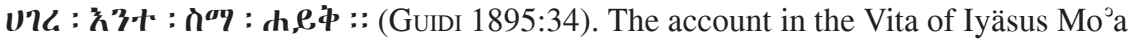
is enlarged by details describing how Iyäsus $\mathrm{Mo}^{\circ} \mathrm{a}$ went to Hayq following a directive from Archangel Gabriel (KuR 1965, 21:20-22:7).

${ }^{77}$ KUR 1965, 34:22-35:11.

${ }^{78}$ KUR 1965, 35:12-36:17.

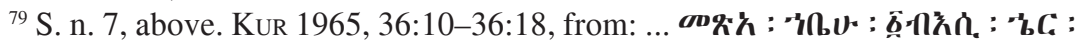

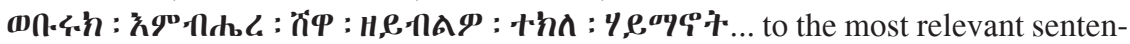

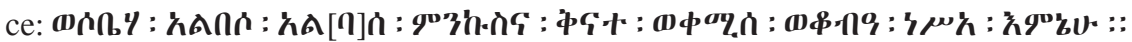

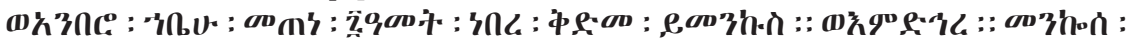

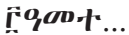

${ }^{80}$ KUR 1965, 36:18-38:8. 
Yohanni. ${ }^{81}$ While telling Täklä Haymanot to receive the scapular at Däbrä Dammo, Iyäsus $\mathrm{Mo}^{\circ}$ a himself confirms that he went from Däbrä Dammo

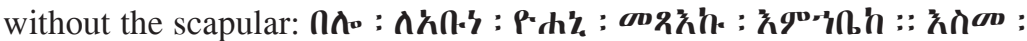

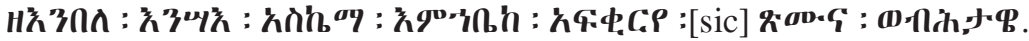
The sentence is related to the corresponding passage from the Vita of ZäMika ${ }^{2}$ el Arägawi and closely follows it, though with one correction. ${ }^{82}$ Further on, Iyäsus $\mathrm{Mo}^{\circ} \mathrm{a}$ explains why he went without receiving the scapular: he was involved in a political struggle on the side of Yəkunno Amlak and could not return. ${ }^{83}$ On the following pages, the Vita of Iyäsus $\mathrm{Mo}^{5} \mathrm{a}$ narrates how Täklä Haymanot came to Däbrä Dammo and met Yohanni (extensively drawing upon the Vita of Zä-Mika el Arägawi, with the difference that it refers to the scapular only) and indicates that Täklä Haymanot received the scapular from Yohanni and spent 7 years at Däbrä Dammo. ${ }^{84}$

III. This part relates how Täklä Haymanot, being on the way from Däbrä Dammo to his native region, met Iyäsus $\mathrm{Mo}^{3}$ a for the second time. ${ }^{85} \mathrm{He}$ brought the scapular and delivered it to his spiritual father, not only fulfilling the latter's order, but also obeying the request of $a b b a$ Yohanni. The hagiographer agrees that Iyäsus $\mathrm{Mo}^{\circ} \mathrm{a}$ accepted the scapular from Täklä Haymanot (but the scapular only: hnh dible from the point of view of both the history and monastic canon, and,

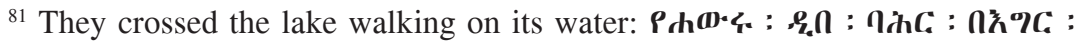

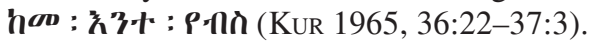

${ }^{82}$ KUR 1965, 37:2-3, cp. the translation: «Je suis jadis de chez toi sans prendre chez toi le scapulaire, ayant aimé le silence at la solitude» (ibid. 30 [tr.]). Also above,

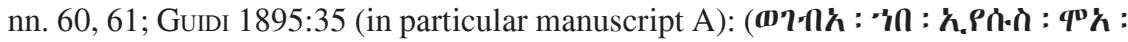

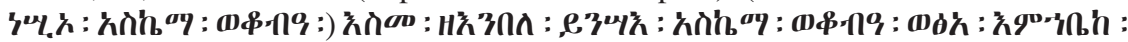

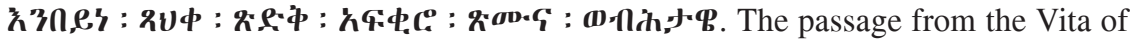
Zä-Mika ${ }^{2}$ el Arägawi was transformed into direct speech; the scribe probably took

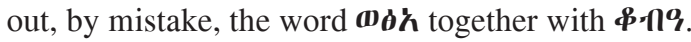

${ }^{83}$ In a difficult phrase, clearly influenced by Amharic speech, Iyäsus $\mathrm{Mo}^{\mathrm{J} a}$ asks Täklä Haymanot to transmit his request to Yohanni and bring him the scapular from

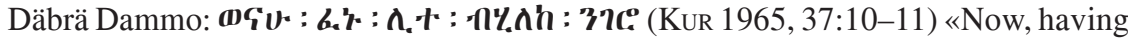
said to him: send (it) for me, tell him (all this)!» (the French translation in ibid. 30 [tr.] is not quite exact).

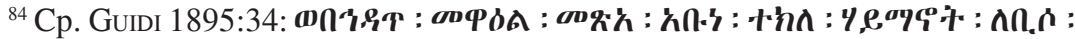

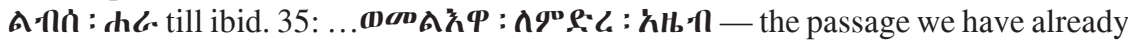
referred to. Cp. Kun 1965, 37:20-38:8. As in other cases, it is impossible to ascertain which text of the Vita of Zä-Mika ${ }^{2}$ el was used; yet the relation between the traditions is transparent, apart from the similar structure of the episode in the both works, cp.,

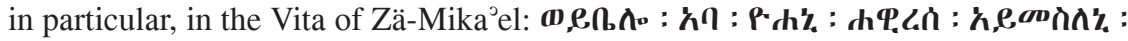

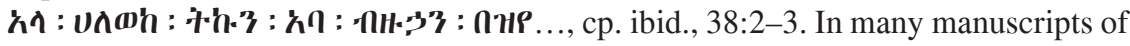
the Vita of Zä-Mika ${ }^{3}$ el Arägawi it is said that Täklä Haymanot spent 7 years at Däbrä Dammo (see n. 58, also n. 6, above); the number 12 does not seem to be the prevailing reading.

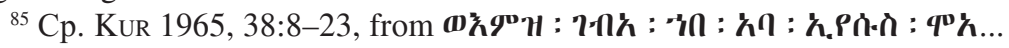


probably, seeing a comparable situation in the Bible, as indicated by the quotation of Jn. 3:27. ${ }^{86}$ By means of the quotation, the hagiographer transposes the story of Iyäsus $\mathrm{Mo}^{\circ}$ a receiving the scapular with the biblical account of the Baptism of Jesus Christ: the interpretation of the story remains, thus, «open», since each of the Saints - both the spiritual father and son, senior and junior — can be considered as the one with «greater grace». ${ }^{87}$ Even though Iyäsus $\mathrm{Mo}^{\circ}$ a humbly accepts the formal initiation from Täklä Haymanot, the one who is junior, the latter fulfils the request of a senior monk and his spiritual teacher; in any case, the consecration of the scapular for Iyäsus $\mathrm{Mo}^{\circ} \mathrm{a}$ had been completed by abba Yohanni and the rest is a purely technical operation. The hagiographer refuses to believe only one thing, which, according to his understanding, is untrue and contradicts both the canons and common sense about monastic life: that up to that time Iyäsus $\mathrm{Mo}^{\mathrm{J}} \mathrm{a}$ had had neither monastic cap nor scapular (asserting, thus, that he had the former) ${ }^{88}$ Unfortunately, we are not able to reconstruct the entire process of the Vita's composition, so we will never learn why its author — being well acquainted with the Vita of Zä-Mika ${ }^{3}$ el Arägawi and perhaps even directly using it for his own work — oversaw or neglected the passage (as the hagiographer from Däbrä Libanos did) which would have removed the doubts: the passage reporting that Iyäsus $\mathrm{Mo}^{\mathrm{a}}$ duly accepted both the monastic cap and scapular from his spiritual father abba Yohanni.

${ }^{86}$ KUR 1965, 38:15-17.

${ }^{87}$ This topic is attested, though rarely, in Ethiopian hagiographies: cp. the Vita of Täklä Hawaryat, in which Täklä Hawaryat and a certain Zär a Ṣəyon, probably his disciple, «imitate» the baptismal ritual in a lake, recalling, thus, the Baptism of Jesus: first Zär’a Şyon, the junior, «baptizes» the saint, and then Täklä Hawaryat, the senior, baptizes Zär ${ }^{\circ}$ a Șəyon (ConTi Rossini 1910:127). Cp. also the Vita of Yohannəs Məśraqawi ( ${ }^{\circ}$ nzä yebel: waldeya kunanni ’aba, MARRASsINI 1981:196-197, esp. n. 2). Besides, one has to remember that in Ethiopia John the Baptist was a popular saint, and the stories about him — or the account on Jesus Christ's Baptism in which God's Son is baptized by a man — used to attract the attention of traditional Ethiopian scholars. Among the Ethiopic writings ascribed to John Chrysostom, there is a Homily on John the Baptist and the Baptism of Christ. A passage of this work, popular and preserved in quite a number of manuscripts, helps to understand the traditional view

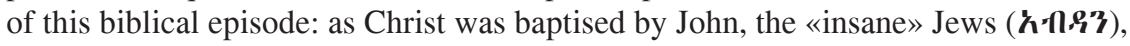
who were observing this, immediately concluded that the latter was «greater». In order to refute this erroneous view, God sent the sign - the dove (Esteves PereirA 1911:6; Portugese translation ibid., 10-11).

${ }^{88}$ This would mean that he was introducing others into monastic life before he himself «was born in the monastic habit». Therefore, the author of the Vita considers this version of events not only as a lie, but also as an offence (which, because of its obvious absurdity, can not be proposed by a reasonable person; hence the reference to «stupid» or «insane», ' KUR 1965, 38:19-39:3. 
3) The third account, like the second, is missing in the Homily. It relates once again how Iyäsus $\mathrm{Mo}^{\circ} \mathrm{a}$ and Täklä Haymanot assumed the monastic habit. ${ }^{89}$ This time, the author of the Vita of Iyäsus Mo ${ }^{3}$ a retells the Vita of Täklä Haymanot, following the Hayq or, most probably, Däbrä Libanos recension as it may be proved, among others signs, by the mention of Täklä Haymanot's encounter with a monk from Amhara before the Saint's arrival at the monastery of Bäșälotä Mika el..$^{90}$ Though the Vita of Iyäsus Mo ${ }^{5}$ b briefly summarises the story, ${ }^{91}$ the sequence of the episodes and the entire structure of the narrative remain the same. The account ends with Iyäsus $\mathrm{Mo}^{\circ} \mathrm{a}$ imposing the monastic yoke upon Täklä Haymanot and vesting him with the «mo-

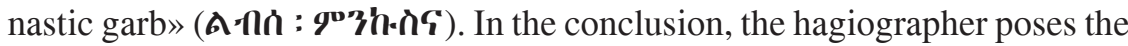
same question once again: how Iyäsus $\mathrm{Mo}^{3}$ a could fulfil this without having reached the proper grade of the monastic profession (i.e., everything except the scapular)? ${ }^{92}$ The arguments used here do not go beyond those presented in the previous account: the hagiographer postulates that Iyäsus $\mathrm{Mo}^{\circ} \mathrm{a}$ «was born in the monastic life» long before Täklä Haymanot's coming; the receiving of the scapular from the hands of Täklä Haymanot, his spiritual pupil, is accepted in the sense indicated above: as the ritual fulfilled according to the spiritual father's request, which does not essentially change the relationship of the «spiritual» fathership. ${ }^{93}$ We can conclude that the author of the

${ }^{89}$ KUR 1965, 39:4-40:4.

${ }^{90}$ As it has already been noted by E. Cerulli (s. KuR 1965:x [tr.]; ibid., 39:4-9); in fact, neither the Hayq nor the Däbrä Libanos version of the Vita of Täklä Haymanot says that the monk whom Täklä Haymanot met on his way to Amhara was «a

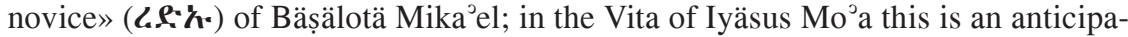
tion typical of a renarration, indicating that the hagiographer had known the text or story in advance.

${ }^{91} \mathrm{Cp}$., in particular, in the Vita of Iyäsus Mo ${ }^{3 a}$ (KuR 1965, 39:9-15), such phrases

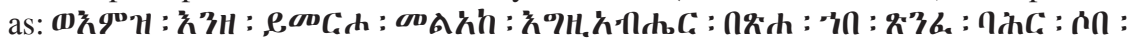

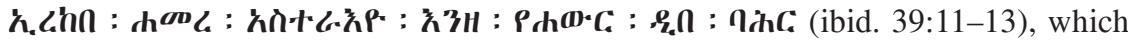
seems to be a corruption of a passage from the Vita of Täklä Haymanot in the Däbrä

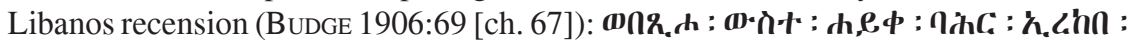

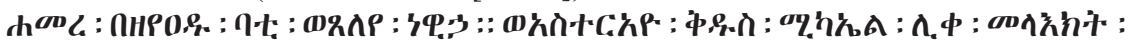
14. : :

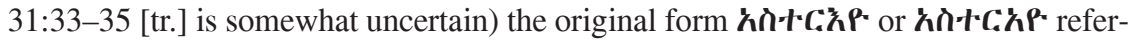
red to the angel; further on, in the Däbrä Libanos recension, Täklä Haymanot, accompanied by the angel, entered the church, whereas in the Vita of Iyäsus $\mathrm{Mo}^{\circ} \mathrm{a}$ he stayed at

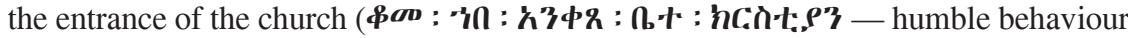
to be expected from a new-comer). Cp. also, respectively,

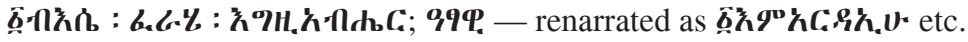

${ }^{92}$ Kur 1965, 39:26-40:4.

93 The Vita strongly prohibits monks to receive the girdle, monastic tunic, cap and scapular from other spiritual teachers; this prohibition appears in the dispositio of one of the «testaments» between Yəkunno Amlak and abba Iyäsus Moª. How- 
Vita of Iyäsus $\mathrm{Mo}^{\circ} \mathrm{a}$ collected and scrutinised all the hagiographic documents relating to how Iyäsus $\mathrm{Mo}^{\circ} \mathrm{a}$ and Täklä Haymanot assumed the monastic habit (though, in fact, he failed to find the necessary evidence!); in order to denounce the versions of the story that he considered untrue, he created a new tradition which - curiously enough - was supposed to be a proof in itself.

The introduction of such a polemic against another monastic leader, which apparently was not caused by any theological controversy or other serious contradiction concerning matters of faith, was pretty unusual for Ethiopian hagiography. It must have had quite a peculiar historical background; in this respect, the question of the dating of the Vita of Iyäsus $\mathrm{Mo}^{\circ} \mathrm{a}$ - and the time when the story in question took its final shape - becomes the primary issue. One more - previously little known — testimony appears to be of considerable importance: a possibly $18^{\text {th }}$-cent. manuscript from the monastery of Däbrä Daga Esțifanos (already quoted above), recently described (Țānāsee $164=$ Dāgā Esțifānos 53 $)^{94}$ and containing, among other texts, the Vita of Iyäsus $\mathrm{Mo}^{\circ} \mathrm{a}$, but in a version different from both the Homily and the Vita known from Kur's edition. A closer investigation demonstrates that this is most probably the «intermediary recension», the document which should be placed between the Homily and the Vita. ${ }^{95}$ This text contains an account of Iyäsus

ever, this passage - certainly intended gainst particular practices in monastic life was written later, since it is missing in the original document, MS EMML 1832, fol. 269r (s. KROPP 1998:309-310).

${ }^{94}$ SIX 1999:207-211.

${ }^{95}$ SIX 1999:209 pointed out to the differences between the Vita and the text preserved in Tānāsee 164; yet the latter is obviously not the shortened text of the Vita, but rather the extended Homily (for the collation below, MS EMML 1960 and MARRASSINI 1986 are used):

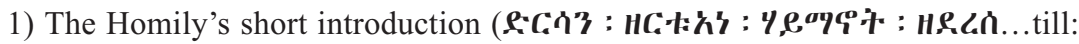

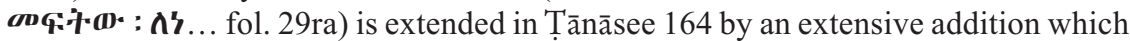

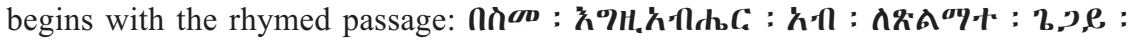

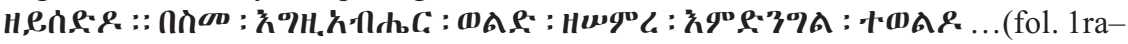

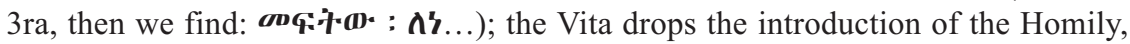
accommodates the introduction from Țānāsee 164 (KUR 1965, 3:18-5:10) and extends the introduction by one more piece (ibid., 1:3-3:17);

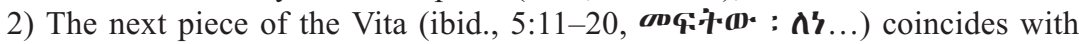
Ṭānāsee 164 (fol. 3rb);

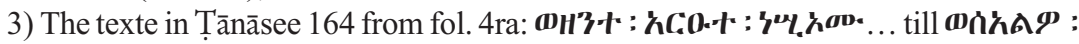

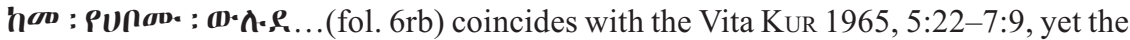
latter has some small additions; thereafter it adds the passage 7:9-8:2. For ibid. 8:2-

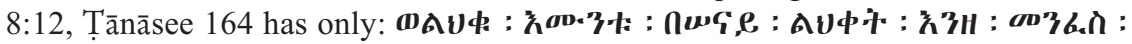

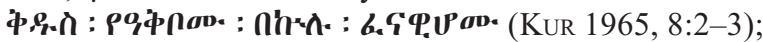

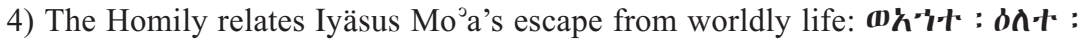

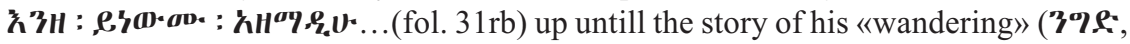
fol. 33rb); the piece from Ṭānāsee 164 fol. 6ra-8ra is the basis for the Vita, s. KuR 


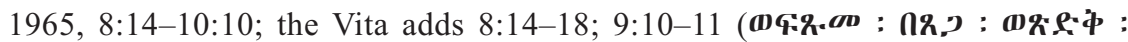

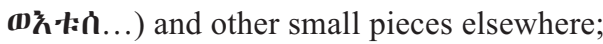

5) The saint's wandering: the texte in Tānāsee 164 fol. 8ra-10rb is mostly the

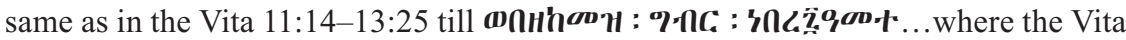
makes here and there small additions; the Vita makes a substantial addition, conti-

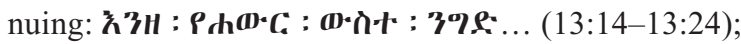

6) In the story about Iyäsus $\mathrm{Mo}{ }^{\mathrm{a}}$ 's monastic consecration Ṭānāsee 164 (fol. 11 ra) omits the name of the saint's mamhər, as does the Homily (fol. 36rb); cp. the Vita, KUR 1965, 14:6. In the sentence describing how Yohanni vested Iyäsus $\mathrm{Mo}^{ } \mathrm{a}$ with parts of the monastic habit, already Ṭānāsee 164 reads albasä mənk ${ }^{w}$ əsənna (fol. 12rb), instead of askema, as in the Homily (s. above; cp. MARRASSINI 1986:179);

7) The story about the accident that happened while the saint was splitting wood with an axe coincides with Țānāsee 164 (fol. 13ra-14rb) and the Vita (KuR 1965, 15:24-17:7), as does the story about salvation of the jar (respectively, fol. 14rb-15ra; KUR 1965, 17:8-20);

8) The history of Däbrä Hayq (in the Vita s. KuR 1965, 17:21-19:27) is missing in

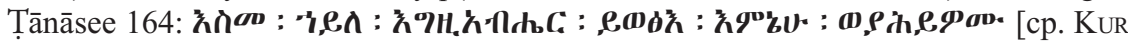

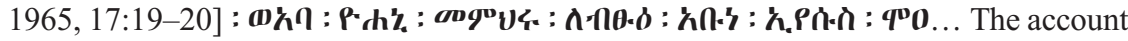
continues with the story of the life of $a b b a$ Yohanni (ibid. 20:1-20); cp. the Vita: $\mathbf{0}$ (n) $\mathbf{c}$ :

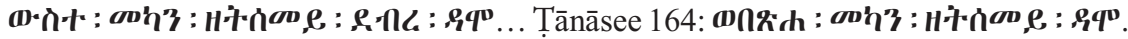
Notes on Gäbrä Șəyon's life and death follow (ibid. 20:21-21:3; 'Ṭānāsee 164, fol. 16rb); and then in Tāāāsee 164 the story of Iyäsus Mo ${ }^{2}$ a's migration to Hayq, simplified and

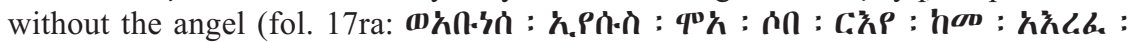

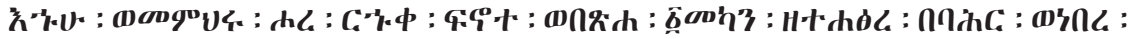

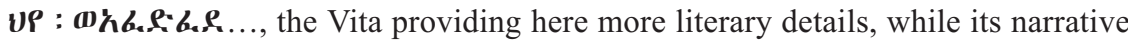
develops somewhat differently (KUR 1965, 21:13-22:8). Lengthy pieces of the Vita are missing in Țānāsee 164, which coincides with the Vita only in the concluding

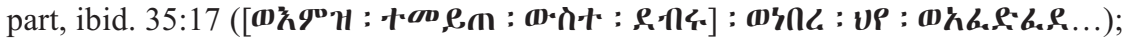

9) The description of Iyäsus Mo'a's pious life on Hayq in his Vita (KuR 1965,

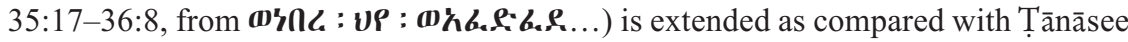

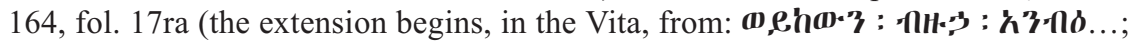
the texts converge at the quotation from Ps. 83:11; s. KUR 1965, 36:7-9);

10) The story about Täklä Haymanot Kur 1965, 36:10-36:18 appears in Ṭānāsee 164 (fol. 17ra);

11) Ṭānāsee 164 does not contain other stories about Täklä Haymanot, and conti-

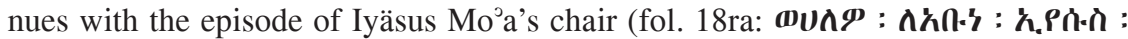
qo'...; Kur 1965, 40:5-13);

12) There is a passage of the Vita (KUR 1965, 40:14-41:4) containing some pieces of the Homily which do not appear in the corresponding portion of TTānāsee 164 (fol. 18ab);

The rest of the text in TTānāsee 164 corresponds to the Homily and to the Vita (cp. also MARRASSINI 1986:180-182), yet the collation demonstrates that it is closer to the Homily and was the basis for the further elaboration in the Vita (mostly revision of style and «decorative» additions); the text in Țānāsee 164 ends at KuR 1965, 54:11. The colophon is, thus, different from that in the Homily (it does not mention Sofonyas; s. MARRASSINI 1986:182). 
Mo'a's assumption of the monastic habit identical to the account 1) of the Vita; therefore, the change of «the scapular of Christ» into «the monastic garb» was made first in the account in Țānāsee 164, possibly for purely stylistic, not ideological, considerations (both terms meaning «monastic habit»); the latter variant was taken over into the Vita of Iyäsus $\mathrm{Mo}^{5} \mathrm{a} .{ }^{96}$ There is only one narrative on Täklä Haymanot's assumption of the monastic habit that corresponds to the (rather neutral) account 2)-II. of the Vita of Iyäsus Mo ${ }^{5} a{ }^{97}$ As the first possibility, we should assume that this text is a genuine document that originated in the community of Däbrä Hayq and reflects its position concerning the spiritual relationships between Täklä Haymanot and Iyäsus $\mathrm{Mo}^{ } \mathrm{a}$. The relevant traditions - different recensions of the Vita of Täklä Haymanot, the Vita of Zä-Mika ${ }^{3}$ l Arägawi - were certainly well-known at the time of the creation of this «short» Vita of Iyäsus $\mathrm{Mo}^{\mathrm{a}} \mathrm{a}$; however, those who composed the text simply did not consider the episode as «contradictory» and were not keen on «rectifying» the history. On the basis of the material that we presently have, the time of the composition of the «lengthy» Vita of Iyäsus $\mathrm{Mo}^{\mathrm{a}}$ a should be therefore dated to a later period — during the $19^{\text {th }}$ cent. - since it is hardly possibly that Iyäsus $\mathrm{Mo}^{ }{ }^{\mathrm{a}}$ 's biography would have been revised twice within such a short period of time. Consequently, the polemical passages found in the «lengthy» Vita should reflect the contemporary (19 $9^{\text {th }}$ cent.?) views of the community.

My hypothesis concerning the recent character of the «contradiction» is corroborated by its ideological and literary context. The preliminary search for traces, which the controversy must have left in the written tradition of both monasteries, brought rather disappointing results. Documents from Däbrä Hayq which deal with the «monastic carrier» of Iyäsus $\mathrm{Mo}^{\circ} \mathrm{a}$ appear to be of recent origin; none of them pays much attention to the question of how

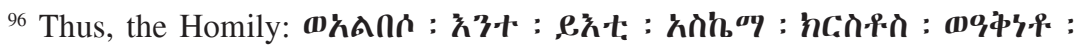

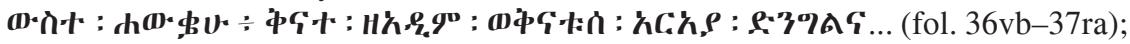

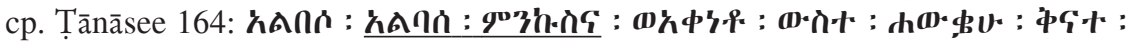

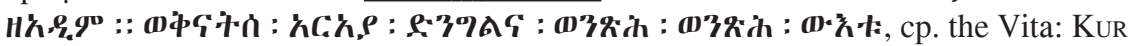
1965, 15:2-4 (s. above, n. 75, also n. 95); after all, it is unprobable that the author of the Vita would have omitted the mention of the scapular.

${ }^{97}$ Ṭānāsee 164 (fol. 17ra): (1)

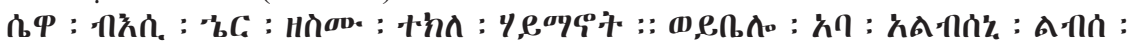

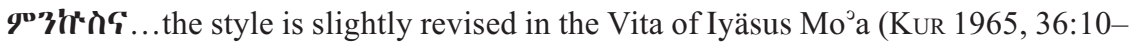
36:18): (0)

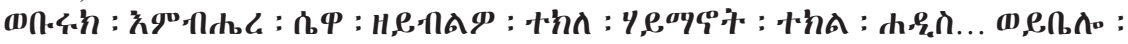

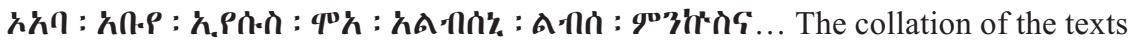
(Ṭānāsee 164, fol. 17b; KUR 1965, 36:10-36:18) demonstrates that from the words

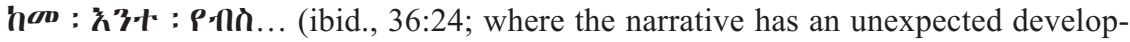
ment concerning the travelling direction of Täklä Haymanot) the Vita adds new passages the origin of which is discussed above. 
exactly Iyäsus $\mathrm{Mo}^{\circ} \mathrm{a}$ assumed the monastic habit, and none contains polemical passages comparable to those found in the Vita of Iyäsus Mo ${ }^{5} .^{98}$ However, some of them describe the monastic carrier of Iyäsus $\mathrm{Mo}^{\circ} \mathrm{a}$ in a peculiar way; of particular interest is the lengthy «History of the Churches and Monasteries of Ethiopia» ${ }^{99}$ in MS EMML 1942, linked to the cycle of Homilies in honour of Archangel Uriel, obviously of Mənilək II's period (and of Šäwan origin). According to the colophon of this work (which deserves, in fact, a closer look), it was composed by a certain ${ }^{c} a q q a b e$ sä ${ }^{c} a t$ Yohannəs, the contemporary of King Ləbnä Dəngəl (1508-40). The History is certainly a pseudoepigraphic work of a much later period, and was probably not composed at Däbrä Hayq; the ideological background of its author is not quite clear, and the work should not prematurely be described «pro-Šäwan». ${ }^{100}$ In any case, it speaks more about Täklä Haymanot than about Iyäsus $\mathrm{Mo}^{\circ} \mathrm{a}$; the account concerning Täklä Haymanot follows his Vita in the Däbrä Libanos recension, and the author of the History shows no interest in taking up the occasion to raise the discussion and revise the story about Iyäsus $\mathrm{Mo}^{\mathrm{J}}{ }^{\mathrm{a}}$ 's assumption of the monastic habit, unless the absence of the author's clear position should be considered an attempt to hide details of Iyäsus Mo a's life. ${ }^{101}$ Otherwise,

${ }^{98}$ While working on his well-known essay (TADDESSE TAMrat 1970), Taddesse Tamrat managed to gain access to and consult the unique sources preserved in Däbrä Hayq; however, he apparently did not find any material which would have lead him to discuss the problem in his article and/or start its closer investigation.

${ }^{99}$ MS EMML 1942, fol. 67b-85a.

${ }^{100}$ Cp. also Getatchew Haile's comments, EMML V, 440.

${ }^{101}$ Here is the relevant passage according to MS EMML 1942. It is related that Täklä Haymanot was born in the seventh year of the reign of Nä’akk ${ }^{w}$ əto Lä-Ab at the age of 22 years he left his parents, quitting the worldly life. Thereafter, the Saint had preached and built churches in Kätata, Damot, Bnnarya etc. Thereafter, «(72vb) saint Uriel ordered him to learn the monastic law from Bäșälotä Mikael of the country of Amhara, in order to become the father of all holy monks of the land of Ethiopia [H-fh/: : $\mathbf{h} \cdot \boldsymbol{T} \cdot \boldsymbol{P} \cdot \boldsymbol{k}, \boldsymbol{P}]$. He went and stayed (there) 10 years, learning the monastic law and making signs while healing the sick. And thereafter Saint Uriel ordered him to go to Lake Hayq and stay with Iyäsus $\mathrm{Mo}^{3} \mathrm{a}$. And he stayed with him 10 years. And after this, he departed from $a b b a$ Iyäsus $\mathrm{Mo}^{\circ} \mathrm{a}$ and ascended (73ra) Däbrä Dammo, to $a b b a$ Yohanni; and he stayed with him 12 years». Täklä Haymanot travelled to Jerusalem three times, till the Patriarch Michael ordered him to stay in Ethiopia to promote monasticism. «(73rb) And after this (73va) he returned from the Patriarch abba Michael and ascended Däbrä Dammo, to $a b b a$ Yohanni. And he told him what the Patriarch said, all his words. And thereafter abba Yohanni responded to him and said: 'I heard [it] from the mouth of all holy monks, the beloved of Our Lady Mary, and they told me that you would be the father of holy monks of the monasteries of all [the country

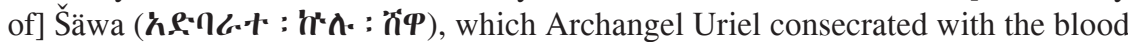
of Christ... Go there and stay there... (73vb)' And after this he left Däbrä Dammo and went to Däbrä Libanos, after he [reached the age of] 70 years after he had been 
at first glance there are no Däbrä Hayq documents concerning the biography of Iyäsus $\mathrm{Mo}^{\mathrm{J}} \mathrm{a}$, except for his Vita, which would deal with the episode in a very different way, speaking from an articulated and consequently ideological position. ${ }^{102}$

An additional last group of documents worth noting is represented by monastic spiritual genealogies and other texts of this kind. These sources have not yet been a subject of comprehensive research; yet many of them mention both Täklä Haymanot's and Iyäsus Mo'a's assumption of the monastic habit, thus recording the relationship between the two saints. The spiritual pedigree of Täklä Haymanot, which follows the Däbrä Libanos recension of his Vita, was compiled simultaneously with or, most probably, somewhat later than the latter, and spread throughout Ethiopia in numerous copies. ${ }^{103}$ Taking into account the fact that the genealogies show numerous variations

born... And in the second year after his entering Däbrä Libanos, the Orthodox King Yəkunno Amlak reigned through the prayer of this father [who] anointed him by his [own] hand with the pure anointment of the kingdom. And it was fulfilled what was called «the miracle of his name» in the Homily of Urael...» The King went to Roha, visited Lalibäla and built another one church — Gännätä Maryam, which Täklä Haymanot consecrated. «(74rb) And after this Yəkunno Amlak went to the island of Lake Hayq and built a church for Iyäsus $\mathrm{Mo}^{a}$ and called it Däbrä Nägwädgwad...(74rb)

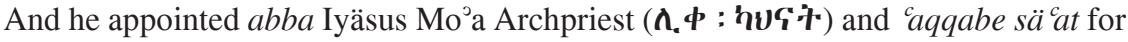
the entire country of Ethiopia, and he said to Täklä Haymanot: «Bring all your [spiritual] sons that you generated through the Holy Spirit, so that they will construct and build church[es] in the name of our Lady Mary, the Mother of God (74va), on all the mountains that Saint Uriel blessed with the blood of our Lord Jesus Christ. And Täklä Haymanot chose from his [spiritual] sons 33 who took the monastic cap and scapular from his hands...»

${ }^{102} \mathrm{Cp}$. also the Miracles of Iyäsus Mo a (EMML 1940, $19^{\text {th }}$ cent., from Däbrä Hayq Bsțifanos; the Miracles seem to post-date the bulk of Iyäsus Mo'a's hagiography, and sometimes draw upon his Vita) which begin with the account of how Iyäsus $\mathrm{Mo}^{\mathrm{j}}$ a left his family at the age of 40 and went to Däbrä Dammo where he spent 7 years with $a b b a$ Yohanni. The author of the Miracles does not provide details on Iyäsus Mo'a's assumption of the monastic habit - tunic, monastic cap and scapular (fol. 69-70, s. also MARRASSINI 1986:183; unless the reference to Iyäsus Mo ${ }^{\circ}$ a as a

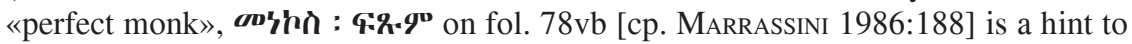
his complete monastic profession).

${ }^{103}$ The earliest edition of such a text, from MS Paris, Bibliothèque national de France, Éth. 160 is in BASSET 1896:15-16. Some time in the late $17^{\text {th }}$ or $18^{\text {th }}$ cent. this genealogy was combined with a short description of Täklä Haymanot's life deriving from the Däbrä Libanos recension of his Vita and became known as the «Genealogy of our fathers, the monks». The account renarrates the life of Täklä Haymanot, taking its start from his spiritual genealogy (this spiritual genealogy is missing in BUDGE 1906, which has only its «short» variant in ch. 88; in manuscripts with the original Däbrä Libanos recension of the Vita this genealogy usually stands before the Homily 
which reveal that their creators could easily «reinterpret» different points of the Ethiopian monastic history, we can not escape the impression that the episode in question failed to attract particular attention, and did not generate resentment or polemic in monastic circles (at least untill a certain moment). The episode is sometimes found in the spiritual genealogies of those monks whose communities were distant from both Däbrä Libanos of Šäwa and «the house of Täklä Haymanot» in Azäzo near Gondär, with the variant of the story rejected by the hagiographer of Däbrä Hayq Hsțifanos apparently dominating, but sometimes difused and/or incorporated into other traditions. ${ }^{104}$ Some of the genealogies omit central details of the story or mutilate it, or depart from its main framework, probably making reference to different traditions. ${ }^{105}$ On the whole, though the topic of spiritual fathership appears important, the genealogies do not focuse on the monastic habit and do not create on its basis any claim for superiority.

on the day of his translatio, following the Vita and the family genealogy of the Saint). It tells that Yohanni «begat» Iyäsus $\mathrm{Mo}^{\circ} \mathrm{a}$ with qämis and qənat, and Iyäsus $\mathrm{Mo}^{\circ} \mathrm{a}$, in turn, «begat» Täklä Haymanot with qämis and qənat; Täklä Haymanot received $q o b^{c}$ and askema at Däbrä Dammo, from Yohanni; as he came back, he gave $q o b^{c}$ and askema to his spiritual father, following the request of the latter (GETATCHEW HaILE 1982-1983:9-10, 23-24 and n. 12).

${ }^{104} \mathrm{Cp}$. the spiritual genealogy of Mädhaninä $\mathrm{ggzi}^{\mathrm{j}}$, the founder of Däbrä Bank ${ }^{w} \mathrm{al}$ in Šəre, Təgray (ConTI Rossinı 1943:337): «Yohanni generò Iyasus-Mo’a e TaklaHāymānot: generò Iyasus-Mo'a col camice e col cingolo e Takla-Hāymānot col cappuccio e con la scapolare. Takla-Hāymānot generò Madḩanina-'Egzi' di Bankual»... Cp. the genealogy from the monastery of Gundä Gunde: «Mädhaninä Bgzi generated Mäsqäl Mäwa ${ }^{\supset}$, and Mäsqäl Mäwa ${ }^{\supset} i$ generated Yoḥanni, and Yoḥanni generated Iyäsus $\mathrm{Mo}^{\circ} \mathrm{a}$, and Iyäsus $\mathrm{Mo}^{\circ} \mathrm{a}$ generated our father Täklä Haymanot with the tunic and girdle and the garb [\%\%:], whereas he took the scapular and [monastic] cap from abba Yohanni of Dammo, who is the father of his father in spirit ... And our farther Täklä Haymanot generated $a b b a$ Mädhaninä Ggziº of Bonkäl...» (MoRdiNI 1952:56, 58).

${ }^{105}$ In MS EMML 1440, a brief monastic genealogy from Anthony the Great until a certain Läbbawi Krəstos states that Iyäsus $\mathrm{Mo}^{3} \mathrm{a}$ was the spiritual son of Yohanni, but neither mentions Täklä Haymanot nor contains any further details about Iyäsus $\mathrm{Mo}^{\circ} \mathrm{a}$ (fol. 58ra-vb). Cp. also the genealogy of the disciples of Iyäsus $\mathrm{Mo}^{\circ} \mathrm{a}$ from EMML 1960, fol. 28vb, in which nothing is said about Iyäsus Mo'a's spiritual father, whereas a certain Täklä Haymanot is mentioned only after some generations, as the spiritual son of Gäbrä Gndrəyas. Besides, cp. the genealogy of Däbrä Libanos monks (from Anthony the Great to the early $17^{\text {th }}$-cent. abbot Abrəham) from the manuscript of the Catholic mission in Kärän (ConTI RossinI 1904:238-240): here Iyäsus Mo ${ }^{3 a}$ comes to Däbrä Dammo and receives from Yohanni the monastic cap and scapular;

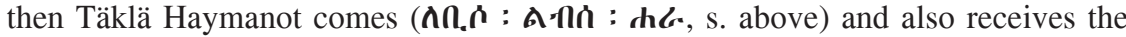
monastic cap and scapular; then Täklä Haymanot comes to Iyäsus $\mathrm{Mo}^{\circ} \mathrm{a}$, and, following the request of the latter, hands the monastic cap and scapular over to his 


\section{III}

We have been tracing the episode which constitutes the «controversial point» of Ethiopian Church history through a number of sources. Indeed, this episode is also recorded, among others, in old traditions - a fact which speaks for its historicity. However, having studied it from different points of view, we are less certain than before as to what degree the episode reflected in the relevant texts is «controversial». Between the earliest attestation of the story and the time it could have taken place there remains a gap of more than 100 years. As the story took the form of a written account, it started to change its shape, but, apparently, very little of actual «ideological revision» can be found in any of its alterations. By the time of the creation of the Waldəbba recension of the Vita of Täklä Haymanot, it was already a remembrance of the honourable past of Ethiopian monasticism shaped as a hagiographic account - shared by all sides involved - Däbrä Libanos, Däbrä Hayq Jsțifanos, Däbrä Dammo; this is supported by the story of monastic career of Täklä Haymanot as presented in EMML 1834 of the Däbrä Hayq and EMML 8742 of the Tana Qirqos. The tradition of Däbrä Dammo contributed an important element to the hagiographic representation of the episode some time in the late $15^{\text {th }}$ early $16^{\text {th }}$ cent.; the fact that the author of the Däbrä Libanos recension took from the Vita of Zä-Mika ${ }^{3} \mathrm{l}$ Arägawi one particular interpretation of the story, is possibly an example of the biased approach of hagiographers. As to the rest, the pieces of evidence, which are extracted from sources prior to the creation of the lengthy recension of the Vita of Iyäsus Mo ${ }^{\circ}$ a, can hardly be interpreted as reflecting the rivalry between Däbrä Libanos of Šäwa and Däbrä Hayq Hsțifanos, especially if they are looked at in a broader literary (hagiographical) ${ }^{106}$ and hi-

spiritual father. Finally, cp. a brief account about Täklä Haymanot's wanderings in the Vita of Tadewos, the founder of Däbrä Maryam on Tana lake (in fact, this work narrates the deeds of Tadewos in southern Ethiopia; SIX 1975:136-139). Cp. a very peculiar genealogy from MS EMML 5117: «Yosef begat Mäsqäl Bezanä, and Mäsqäl Bezanä (begat) Mädḩaninä Ggzi ${ }^{\supset}$, and Mädhaninä $\operatorname{Ggzi}^{\top}$ (begat) Mäsqäl Mäwa i, and

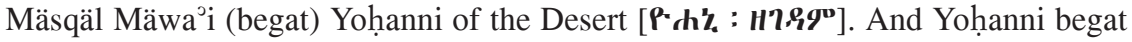
Iyyäsus $\mathrm{Mo}^{\circ} \mathrm{a}$, the Leaf of Sabbath; Arsesayus, the Grass of Sabbath [0त\&.ov: :

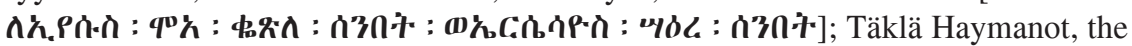

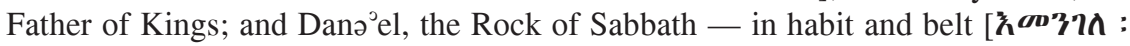

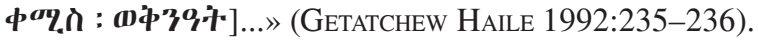

${ }^{106}$ Within the scale of the present study it is difficult to assess how far hagiographers could or wanted to go in depicting or alluding to conflicts or controversies with other communities, which certainly could have taken place. An answer may to be looked for in defining the general aesthetic principles of Ethiopian hagiography as a literary genre (this being linked to a larger problem, particularly important for Ethiopian studies: elaborating reasonable criteria for critical approach to hagiographic 
storical context, ${ }^{107}$ including considerations as to the role and position of the monastic investiture in traditional monastic culture.

sources) and in a careful study of each single case. It is, indeed, striking that the $17^{\text {th }} /$ $18^{\text {th }}$-cent. controversies between the Täwahədo and Qəbat religious fractions, in which many monasteries took an active part, left relatively few direct traces in the hagiographies known so far. At the same time, most remarkable in this respect is the Vita of Zä-Mika el Arägawi, which ascribes to the Saint such a central role in Kaleb's campaign as is played, in fact, by his «twin» abba Päntälewon - according to the latter's Vita. We can only speculate how this alternative description of Kaleb's campaign to Yemen was perceived by representatives of Betä Pänțälewon (the political decline of which was also accompanied by the transfer of economic benefits to Däbrä Dammo). These transformations may find typological correspondences in some other cases (one can remember, e. g., that the leading role in the confrontation of monks with King ${ }^{\mathrm{c}}$ Amdä Şəyon I is also contested by several hagiographic traditions), yet the accounts of the monastic initiations of the saints seem hardly ever to have been exploited in this respect. The most peculiar «deviation» from the common patterns that could have caused concerns may be the motive of receiving of the monastic habit or its part from God, but it appears in only a very few hagiographies, though in those of the most venerated monks (Gäbrä Mänfäs Qəddus, Zär ${ }^{\circ}$ a Buruk, Filəpppos of Däbrä Bizän, and also Täklä Haymanot), and remains «closed» — the hagiographers did not pick this element for promoting any claims.

107 The idea of the controversy between Däbrä Libanos and Däbrä Hayq Hsțifanos, and the mutual attempts at limiting the respective influence by means of reversing the spiritual filiation (DERAT 2003:108) should be attenuated. It is not the place here to discuss in details the history of either Däbrä Libanos or Däbrä Hayq; but it is difficult indeed to find direct references to any serious controversy of an economic, political or religious nature (e. g., transfer of land possessions and titles; different positions in theological controversies etc.) between Däbrä Hayq and Däbrä Libanos. The rise of Däbrä Libanos happened long after Däbrä Hayq became an established royal sanctuary. In the $15^{\text {th }}$ cent., in particular during the reign of Zär ${ }^{\mathrm{j} a} \mathrm{Ya}^{\mathrm{c}}$ əqob, both monasteries passed through periods of royal favour and disfavour, which had imme-

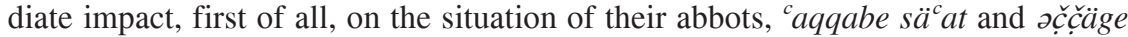
respectively, who spent much time at the court (with the consequence of weakening direct links to their communities). From the beginning of the $16^{\text {th }}$ cent. at least, the ə⿳亠丷冖̆ăge was nominated the head of all Ethiopian monks; however, the ${ }^{c}$ aqqabe sä $\ddot{a}^{c}$ at undoubtedly enjoyed high prestige and influence as well (in fact, differences could occasionally appear between them). In the $15^{\text {th }} /$ early $16^{\text {th }}$ cent., the economic situation of Däbrä Hayq was improving thanks to donations (s. TADDESSE TAMRAT 1970). The spheres of direct influence of both monasteries hardly overlapped due simply to the considerable distance separating them. Däbrä Libanos's religious and administrative presence was substantial in particular in the southern regions of the Kingdom, where it administered missionary activities and ecclesiastic matters. Possibly, these constraints contrasted with the meditative asceticism of Däbrä Hayq (the ideal reflected in the Homily of Iyäsus $\mathrm{Mo}^{\mathrm{a}} \mathrm{a}$, Acts of Bäggə ${ }^{\mathrm{c}}$ and elsewhere). In fact, the reconstruction of the «monastic network» of Däbrä Hayq Usțifanos — the ecclesiastic organization thought to be a rival of Däbrä Libanos — is mostly based on the in- 
The «lengthy» recension of the Vita of Iyäsus $\mathrm{Mo}^{ } \mathrm{a}$, containing numerous «testaments» between the Saint and King Yəkunno Amlak, is a unique piece of evidence. Certainly, it may have been a response to the late $17^{\text {th }}$ /early $18^{\text {th }}$-cent. «Riches of the Kings» of the «house of Täklä Haymanot» and the claims of Däbrä Libanos of Šäwa. But, in view of its complex textual history and its possible historical context, the work appears to be of a more recent origin than has been suggested before: it was created after the «intermediary recension» of the Vita (or «the short Vita») attested in MS TTānāsee $164=$ Dāga Esțifānos 53 which was the continuation of the textual tradition of the Homily. The fact that the «lengthy» recension of the Vita of the Saint is hitherto known only from two $19^{\text {th }}$-cent. manuscripts betrays the rather late and local character of the «controversy». Thus, the latter's possible causes should be looked for in the recent history of Däbrä Hayq, ${ }^{108}$ in particular, in the age of Yohannes IV and Mənilək II, when the gradual movement towards a centralized state began to take shape. By then, the ancient sanctuary of Däbrä Hayq Esțifanos attracted the attention of the Ethiopian lords. At some point during this period, intending to use the opportunity and resume its high position in the national Church hierarchy, the community of Däbrä Hayq Hsțifanos may have compiled and presented a new complete version of the Vita of Iyäsus $\mathrm{Mo}^{\mathrm{D}} \mathrm{a}$, the most prominent monk of the community, producing new evidence about the valuable services he rendered to the Solomonic rulers, ascertaining his fame, and denouncing old rumours which could have cast doubts upon his fame.

formation from the Vita of Iyäsus $\mathrm{Mo}^{\mathrm{J}} \mathrm{a}$; yet the claims made in this Vita usually find no confirmation in local monastic traditions; it is unknown how such a «monastic network» could have been organized (DERAT 2003:110-119).

${ }^{108}$ This is not an easy task, for the history of the monastery during the late $17^{\text {th }} /$ $19^{\text {th }}$ cent. - the time it kept out from big events - remains less well known. In the $16^{\text {th }}$ cent., Däbrä Hayq did not suffer a complete devastation like Däbrä Libanos. In the second half of the $16^{\text {th }}$ cent., Däbrä Libanos revived and occupied the leading role in the kingdom, but already in the early $17^{\text {th }}$ cent. a major part of its community moved to the region of lake Tana, to settle later in Azäzo, whereas the original Däbrä Libanos remained in decline until the beginning of the $19^{\text {th }}$ cent. Both the ${ }^{c}$ aqqabe

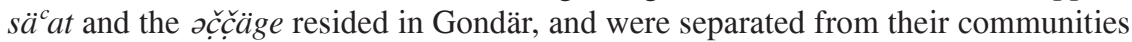
and involved in theological controversies and political intrigues. In the $18^{\text {th }}$ cent., the titles were sometimes bestowed upon the representatives of other monasteries (under Bäkaffa, re. 1721-1730, the title of ${ }^{c}$ aqqabe sä $\ddot{a}^{c}$ t was given to the head of Däbrä Məțmaq). Since at least the $18^{\text {th }}$ cent., while «the house of Täklä Haymanot» retained importance, Däbrä Hayq was constantly endangered by Oromo Marawwa and Wällo, and later by Wällo's Islamic rulers. The Christian population remained only in the vicinities of the monastery. Only from the time of Yohannəs IV (1872-1889) did the monastery gain support again, and favour by the kings and nobles (as appears from land charters registered in MS EMML 1940). 


\section{Bibliography}

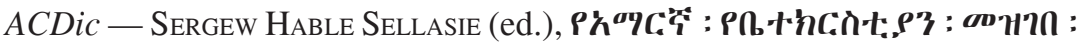

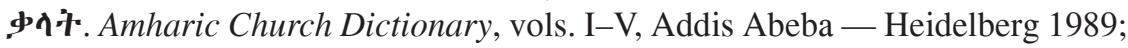

Balicka-Witakowska, E. (1998-99), «Les peintures murales de l'église rupestre éthiopienne Gännätä Maryam près de Lalibela», Arte medievale ser. 2, 12 13, 193-209;

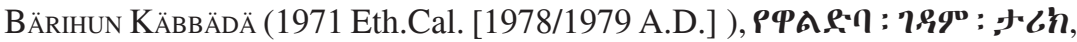
Addis Abäba;

BASSET, R. (1896), Les apocryhes éthiopienn. VI. Les regles attribuées à SaintPachôme, Paris;

Bausi, A. (2003), La «Vita»e $i$ «Miracoli» di Libānos, Lovanii (CSCO 295, 296; SAe 105, 106);

Beckingham, C. F. - Huntingford, G. W. B. (eds.) (1961), The Prester John of The Indies. A True Relation of the Lands of the Prester John, being the Narrative of the Portuguese Embassy to Ethiopia in 1520, written by Father Francisco Alvarez, tr. by Lord Stanley of Alderly (1881), Cambridge (Hakluyt Society Works, ser. 2, vols. 114, 115);

BKK - BAUTZ, F. W. (Hrsg.), Biographisch-bibliographisches Kirchenlexikon, Nordhausen 1975ff.;

Beylot, R. (1976), Abba Nabyud de Dabra Sihat. Visions et conseils ascétiques, Louvain (CSCO 377, 378; SAe 70, 71);

Bolotov, V. [Болотовъ, В. В.] (1898), «Часословъ эфіопской церкви», Христианское чтеніе 2: 189-198;

Budge, E. A. W. (1906), The Life and Miracles of Tâklâ Hâymânôt in the Version of Dabra Libânôs, and the Miracles of Tâklâ Hâymânôt in the Version of Dabra Libânôs, and the Book of the Riches of the Kings, London;

Budge, E. A. W. (1928), The Book of the Saints of the Ethiopian Church. A Translation of the Ethiopic Synaxarium, Cambridge;

Cerulli, E. (1943), «Gli Abbati di Dabra Libanos capi del monachesimo etiopico, secondo la «lista rimata» (sec. XIV-XVIII)», Orientalia NS 12: 226253;

Cerulli, E. (1958), «Il monachismo in Etiopia», in: Il monanachesimo orientale, Roma [=OCA, 153], 259-278;

Cerulli, E. (1961), La letteratura etiopica, Milano.

Chaillot, C. (2002), The Ethiopian Orthodox Tewahedo Church Tradition, Paris;

Colin, G. (1990), Vie de Samuel de Dabra Halleluya, Louvain (CSCO 519, 520; SAe 93, 94);

Colin, G. (1994), Le synaxaire éthiopien. Le mois de Maggābit, Turnhout (PO 46-3);

Conti Rossini, C. (1896), «Il “Gadla Takla Hāymānot”, secondo la redazione Waldebbana», MRALm, ser. v, 2-1: 97-143;

Conti Rossini, C. (1897), «L'omilia di Yohannes, vescovo d'Aksum in onore di Garimâ», in: Actes du XI Congrès des Orientalistes, Paris, 139-177; 
Conti Rossini, C. (1900 [1901]), «Il Gadla Filpos e il Gadla Yoḥannes di Dabra Bizan», MRALm, ser. v, 8: 61-170;

Conti Rossini, C. (1903), Gli atti di Abba Yonas, Roma [= RRALm, ser. v, 12 (1903), 177-202, 238-262];

Conti Rossini, C. (1904), «I manoscritti della Missione Cattolica di Cheren», RRALm, ser. v, 13: 233-286;

Conti Rossini, C. (1905), Vitae sanctorum antiquiorum. II. Acta S. Bașalota Mikā'ēl et Anorēwos, Parisiis (CSCO 28, 29; SAe 11, 12);

Conti Rossins, C. (1910), Vitae sanctorum indigenarum. I. Acta sancti Abakerazun. II. Acta sancti Takla Hawaryat, Romae, Parisiis, Lipsiae (CSCO 56, 57; SAe 13, 14);

Conti Rossini, C. (1943), [review of R. De Santis, Il Gadla Tadewos di Dabra Bartarwa..., Citta del Vaticano 1942], RSE 3: 334-340;

Conti Rossini, C. - Ricci, L. (eds., trs.) (1964-65), Il libro della luce del negus Zar'a Yã'c qob (Mașhafa Berhān), Louvain (CSCO 250-251, 261-262; SAe 47-48, 51-52);

DEB - Belaynesh Michael - Chojnacki, S. - Pankhurst, R. (eds.), The Dictionary of Ethiopian Biography, vol. I: From Early Times to the End of the Zagwe Dinasty, Addis-Abeba 1975;

Derat, M.-L. (1998), «Une nouvelle étape de l'élaboration de la légende hagiographique de Takla Hāymānot (ca. 1214-1313)», Cahiers du Centre de Recherches Africaines 9: 71-90;

Derat, M.-L. (2003), Le domaine des rois éthiopiens (1270-1527). Espace, pouvoire et monachisme, Paris (Histoire ancienne et médiévale, 72);

Dillmann, A. (1847), Catalogus codicum manuscriptorum orientalium qui in Museo Britannico asservantur. Pars Tertia, codices Aethiopicos amplectens, Londini;

Dillmann, A. (1865), Lexicon linguae Aethiopicae cum indice Latino. Adiectum est Vocabularium Tigre dialecti septentrionalis compilatum a Werner Munzinger, Lipsiae;

Dillmann, A. (1866), Chrestomathia Aethiopica, Lipsiae;

Dillmann, A. (1907), Ethiopic Grammar, second edition, enlarged and improved, ed. by C. Bezold, tr. by J. A. Crichton, Amsterdam;

DuChesne-Fournet, J. (1908), Mission en Éthiopie, 1901-1903, Paris, vol. 1;

EMML — Getatchew Haile, William F. Macomber, A Catalogue of Ethiopian Manuscripts Microfilmed for the Ethiopian Manuscript Microfilm Library, Addis Abeba and for the Hill Monastic Manuscript Library, Collegeville, vols. IX, Project Numbers 1-5000, Collegeville 1975-1993;

EnSanti - Enciclopedia dei santi: le Chiese orientali, Roma 1998ff.;

Esteves Pereira, F. M. (ed.) (1899), Vida de Takla Haymanot pelo P. Manuel de Almeida, Lisboa;

Esteves Pereira, F. M. (1911), «Homilia sobre o baptismo de N. S. Jesus Christo attribuda a S. João Chrysostomo (Homilia segunda)», Academia das Sciencias de Lisboa, Separata do «Boletim de Segunda Classe» 4, 10-11: 1-7;

EvetTs, B. (1906), «Le rite copte de la prise d'habit et la profession monacale», ROC sér. $2^{\text {me }}, 1$ [11]: 60-73, 130-148; 
Getatchew Haile (1982-83), «The Monastic Genealogy of the Line of Takla Haymanot of Shoa», RSE 29: 1-38;

Getatchew Haile (1990), «The Homily of Abba Eləyas, Bishop of Aksum, on Mäțța ${ }^{c} »$, Analecta Bollandiana 108: 29-47;

Getatchew Haile (1992), «A Fragment of the Monastic Fathers of the Ethiopian Church», in: P. Scholz et al (eds.), Orbis Aethiopicus: Studia in honorem Stanislaus Chojnacki natali septuagesimo quinto dicata, septuagesimo septimo oblata, Albstadt (Bibliotheca nubica, 3), 231-237;

Girma Elyas (1977), «The Monastery of Abrentant in Waldebba», Abbay 8: 93-117;

Grébaut, S. (1940), Rituel éthiopien de prise d'habit, Paris;

GréBAut, S. (1941), Catalogue des manuscrits éthiopiens de la collection Griaule. Tome second. Sections VII-IX. VII, hagiographie. VIII, homélies-panégyriques. IX, Malke 'e et salâm, Paris (Miscellanea africana Lebaudy, Cahier 3);

Grébaut, S. - Tisserant, E. (1935), Codices Athiopici Vaticani et Borgiani, Barberinianus Orientalis 2, Rossianus 865. Pars Prior: enarratio codicum, Romae;

Guidi, I. (1895), Il «Gadla 'Arag6wo», Roma [= MRALm, ser. v, 2-1 (1894), 54-96];

GuIDI, I. (1901), Vocabolario amarico-italiano, Roma;

Guid, I. (1912), Le Synaxaire éthiopien. III: Mois de Nahasê et de Pâguemên (traduction de S. Grébaut), Paris (PO 9-4);

GuIDI, I. (1932), Storia della letteratura etiopica, Roma;

Hammerschmidt, E. (1962), Symbolik des orthodoxen und orientalischen Christentums, Stuttgart (Symbolik der Religionen, 10) ;

Hammerschmidt, E. - Six, V. (1983), Äthiopische Handschriften. 1: Die Handschriften der Staatsbibliothek der preussischer Kulturbesitz, Wiesbaden (Verzeichnis der orientalischen Handschriften in Deutschland XX, 4);

Hammerschmidt, E. (ed.) (1988), Anthologia Aethiopica. Augustus Dillmann: Chrestomatia Aethiopica. Johannes Bachmann: Anthologia Aethiopica..., Hildesheim — Zürich — New York;

HiRsch, B. (2003), «L'agiographe e l'histoire. Lectures d'un passage des Actes de Iyasus Mo'a», in: Kropp, M., - Hirsch, B. (eds.), Saints, Biographies and History in Africa, Frankfurt am Main (Nordostafrikanisch/Westasiatische Studien, 5), 161-174;

JAEGER, K. (1912), Vitae sanctorum indigenarum. II. Miracula S. Zara-Buruk, Romae, Parisiis, Lipsiae (CSCO 69; SAe 30);

Kaplan, S. (1984), The Monastic Holy Man and the Christianization of Early Solomonic Ethiopia, Wiesbaden (Studien zur Kulturkunde, 73).

Kaplan, S. (1986), «Iyäsus Mo’a und Täklä Haymanot: Note on a Hagiographic Controversy», Journal of Semitic Studies 31-1: 47-56;

KRZ - Kinefe-Rigb Zelleke (1975), «Bibliography of the Ethiopic Hagiographical Traditions», JES 13-2: 57-102;

Kriss, R. - Kriss-HeINRICH, H. (1975), Volkeskundliche Anteile in Kult und Legende äthiopischer Heiliger, Wiesbaden; 
KRopp, M. (1998), «“...der Welt gestorben”: ein Vertrag zwischen dem äthiopischen Heiligen Iyyäsus Mo'a und König Yekunno-Amlak über Memoria im Kloster Hayq», Analecta Bollandiana 116, 3-4: 303-330;

Kropp, M. (2003), «Die dritte Würde oder ein Drittel des Reiches? Die verschiedenen Versionen der Biographie des Hl. Iyäsus Mo'a als Ausdruck sich wandelnden Funktio nen des Textes», in: Hirsch., B., — Kropp, M., Saints, Biographies and History in Africa, Frankfurt am Main (Nordostafrikanisch/Westasiatische Studien, 5), 191-205;

KuR, S. (1965), Actes de Iyasus Mo a abbé du couvent de St. Etienne de Hayq, Louvain (CSCO 259, 269; SAe 49, 50);

KuR, S. (1968), Actes de Samuel de Dabra Wagag, Louvain (CSCO 287, 288, SAe 58, 57);

KuR, S. (1972), Actes de Märha Krestos, Louvain (CSCO 330, 331; SAe 62, 63);

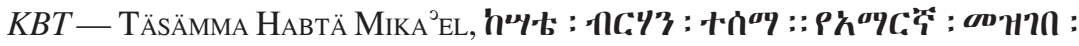
中へ币, Addis Abäba 1951 Eth.C. [1958/59 A.D.];

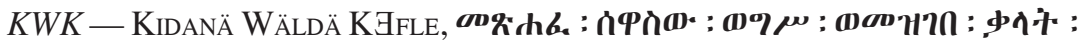
h.?.⿳⺈, Addis Abäba 1948 Eth.C. [1955/56 A.D.];

Leslau, W. (1987), Comparative Dictionary of $\mathrm{Ge}^{c} e z$ (Classical Ethiopic), Wiesbaden;

LTK - Walter KASPER (ed.), Lexikon für Theologie und Kirche, Freiburg im Bresgau 1993-2001;

LusinI, G. (1997 [1999]), «Tradizione e redazione delle regole monastiche etiopiche (Parigi, B. N., ms. éth. 125, ff. 160v-162)», Miscellanea Marciana 12: 53-66 [= Proverbio, D. V. (ed.), Scritti in memoria di Emilio Teza, Roma 1998];

LusinI, G. (1993), Studi sul monachesimo eustaziano (secoli XIV-XV), Napoli (Studi Africanistici. Serie Etiopica, 3);

Marrassini, P. (1981), Gadla Yohannes Mesraqawi. Vita di Yohannes L'Orientale, Firenze (Istituto di Linguistica e di Lingue Orientali Universita di Firenze, Quaderni di Semitistica, 10);

Marrassini, P. (1986), «A proposito di ${ }^{\top}$ Iyasus Mo ${ }^{\circ}$ a», Egitto e Vicino Oriente 9: 175-197.

Marrassini, P. (1990), «Some Consideration on the Problem of the "Syriac Influences" on Aksumite Ethiopia», JES 23: 35-46.

Marrassini, P. (2003), «Vita», «Omelia», «Miracoli» del Santo Gabra Manfas Qeddus, Lovanii (CSCO 597, 598 [SAe 107, 108]);

Matthews, D., - Mordini, A. (1959), «The Monastery of Debre Damo, Ethiopia», Archaeologia [2 ${ }^{\text {nd }}$ ser., 47], 97: 1-58, pls. I-XI;

MordinI, A. (1952), «Il convento di Gunde Gundiè», RSE 11: 29-63;

NosNitZYN, D. (2000), «Zur Literaturgeschichte der Vita des heiligen Täklä Haymanot: die arabische Fassung», Afrikanistische Arbeitspapiere 62: 93-112.

Nosnitsin, D. (2003), «Mäṣhafä fəlsätu lä-abunä Täklä Haymanot: a Short Study», Aethiopica. International Journal of Ethiopian Studies 6: 137-167;

Nosnitsin, D. (2006), «The Ethiopic Synaxarion: text-critical observation on one commemorative text», $O C P$, forthcoming; 
RAIneri, O. (1990 ), Atti di Habta Māryām (†1497) e di Iyāsu (†1508), Santi monaci etiopici, Roma (OCA, 235);

Ricci, L. (1959)-(1969-70), «Le vite di 'Ěnbāqom e di Yohanněs, abbati di Dabra Libānos di Scioa», RSE 13 (1954 [1955]), 91-122; RSE 14 (1955-1958 [1959]), 69-107; RSE 22 (1966), 75-102; RSE 23 (1967-1968 [1971]), 79-219; RSE 24 (1969-1970 [1971]), 134-232;

Ricci, L. (1969), Letterature dell'Etiopia, Milano 1969, in: Storia delle letterature d'oriente, diretta da Oscar Botto, Milano, 811-911;

Ricci, L. (1979), Miracoli di Zar'a Buruk. Traduzione e commento storico, Louvain (CSCO 409; SAe 72);

SAUTER, R., «Où en est notre connaissance des églises rupestres d'Ethiopie?», AÉ 5 (1963), 235-292;

Simon, J. (1941), «Notes sur les textes de la "Chrestomatia Aethiopica”», Orientalia NS, 10: 285-311;

SIX, V. (1975), Die Vita des Abuna Tādewos von Dabra Māriām im Tānāsee, Wiesbaden (Verzeichnis der orientalischen Handschriften in Deutschland, Supplementband 18);

SIX, V. (1989), Äthiopische Handschriften. 2: Die Handschriften der Bayerischen Staatsbibliothek, Wiesbaden (Verzeichnis der orientalischen Handschriften in Deutschland XX, 5);

SIX, V. (1999), Äthiopische Handschriften vom Tänōsee. 3: Nebst einem Nachtrag zum Katalog der äthiopischen Handschriften deutscher Bibliotheken und Museen, Wiesbaden (Verzeichnis der orientalischen Handschriften in Deutschland XX, 3);

Sergew Hable-Selassie (1992), «The Monastic Library of Däbrä Hayq», in: Scholz, P. — Pankhurst, R. — Witakowski, W. (eds.), Orbis Aethiopicus. Studia in honorem Stanislaus Chojnacki natali septuagesimo quinto dicata..., Albstadt (Bibliotheca nubica, 3), 243-258;

SCHneIDER, M. (1972), Actes de Za-Yohannes de Kebrān, Louvain (CSCO 332, 333; SAe 65, 66);

SCHNEIDER, R. (1978), «Notes sur Filpos de Dabra Bizan et ses successeurs», $A E$ 11: 135-139;

Strelcyn, S. (1976), Catalogue des manuscrits éthiopiens de l'Accademia Nazionale dei Lincei. Fonds Conti Rossini et Fonds Caetani 209, 375, 376, 377, 378, Roma;

TAdDESSE TAMrat (1970), «The Abbots of Däbrä Hayq 1248-1535», JES 8-1: 87-117;

TAdDESSE TAMrat (1972), Church and State in Ethiopia 1270-152, Oxford;

TEDESCHI, S. (1994), «La vita del monaco etiope Iyasus Mo’a (sec. XIII): agiografia e storiografia», OCP 60: 503-518;

Thomas, J. - Constantinides Hero, A. (eds.) (2000), Byzantine Monastic Foundation Documents, Washington, D. C. (Dumbartom Oaks Studies, Xxxv), 5 vols.;

TuraieV, В. [ТУРАЕВъ, Б. А.] (1902), Изследованія въ области агіологических источниковъ исторіи Эфіопіи, С.-Петербургъ; 
Turaiev, B. (1902[a]), Vita Samuelis Valdebani, Petropoli (Monumenta Aethiopiae Hagiologica, 2);

Turaiev, B. (1905), Vita et miracula Eustathii, Petropoli (Monumenta Aethiopiae Hagiologica, 3);

Turaiev, B. (1908), Vitae sanctorum indigenarum. II. Acta s. Aronis et s. Philippi, Louvain (CSCO 30, 31; SAe 13, 14);

VAN De Weyer, Robert (1973), «The Monastic Community in Ethiopia», Ethiopia Observer 16-1: 8-14;

Wright, W. (1877), Catalogue of the Ethiopic Manuscripts in the British Museum acquired since the Year 1847, London;

UhLIG, S. (1988), Äthiopische Paläographie, Stuttgart (Aethiopistische Forschungen, 22);

Zotenberg, H. (1877), Catalogue des manuscrits Éthiopiens (Gheez et Amharique) de la Bibliothèque Nationale, Paris.

\section{Appendix}

1) The famous Gäbrä Mänfäs Qəddus was 12 years old when $a b b a$ Zämädä Bərhan «gave him the holy scapular, like Anthony, and girded his loins with «hair

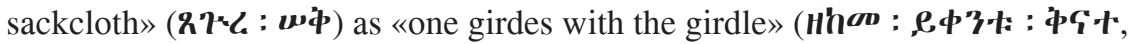
MARRASSINI 2003:12-13[text]; cp. also XL-XLII), whereas in the lengthy Synaxarion note on Gäbrä Mänfäs Qəddus any indication of the assumption of the monastic habit is missing (30 Mäggabit, CoLIN 1994:440-467, BUDGE 1928:755-772).

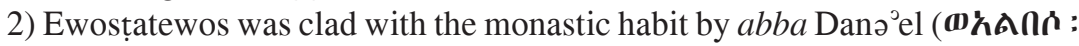

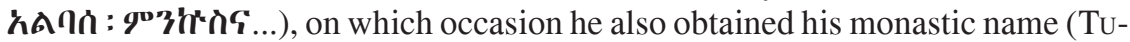
RAIEV 1902:303; TURAIEV 1905:22-23).

3) Having reached the monastic community of $a b b a$ P̣äntälewon, Yəshaq/

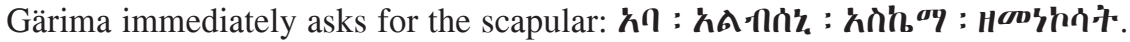
After P̣änțälewon's question as to whether he is ready for the scapular - i. e. the

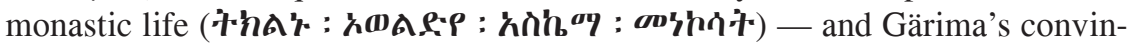
cing response, Pänțälewon confers the scapular upon him: ...'

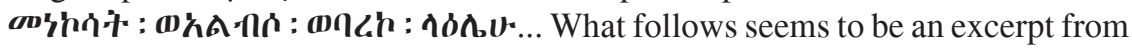
the ritual of the monastic consecration (CoNTI RossinI 1897:152).

4) Zä-Mika ${ }^{3}$ el Arägawi assumed the monastic habit at the age of 19 , from the hands of Pachomius the Great, after a short interrogation to prove the seriousness

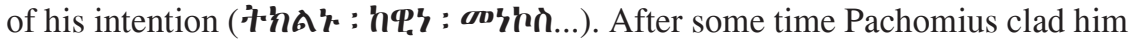

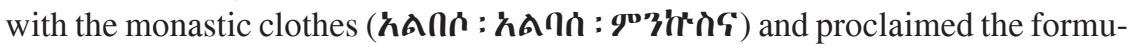
la: «May God bless your scapular as He blessed $a b b a$ Anthony and $a b b a$ Macarius, my fathers» and conferred upon him the new name - Zä-Mika ${ }^{3}$ l Arägawi (Guid 1895:6-7). The same procedure is carried out when Liqanos, Yəmªta, Şəḥma, Guba, Afșe and Pänțälewon (cp. DEB 209-210) come to him, with slight

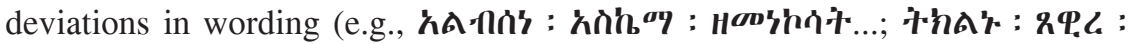

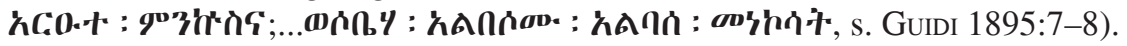

5) The Vita of Libanos/Mätța ${ }^{c}$ reports that he accepted the scapular from Pachomius before leaving for Ethiopia (BAusi 2003, §26; cp. also ibid. [tr.], 9, n. 35; 
the Vita most probably repeats what the ancient Homily [in honour of] Mätța ${ }^{\mathrm{c}}$

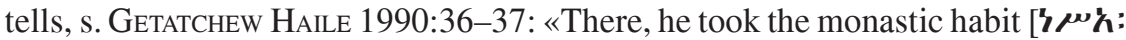

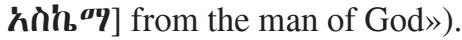

6) According to the Vita of Samu’el of Däbrä Halleluya, when Nä’akwəto Lä$\mathrm{Ab}$ (Samu'el's worldly name) came to the community of abba Jnțonəs, he asked

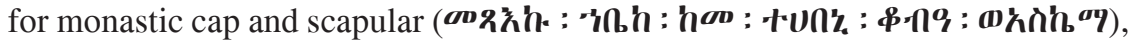

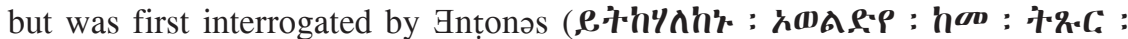

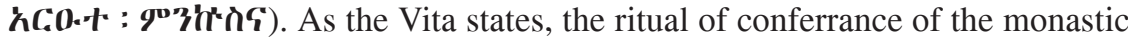
habit was performed according to the Mäṣafä Mənkw əsənna: the monastic cap and scapular were placed in front of the tabot, and the prayer was recited over them; the novice was blessed by all the «saints» (qəddusan), a prayer was performed over him, and he received the monastic cap and scapular and his new monastic name - Samu el (CoLIN 1990:8).

7) Yonas took on the monastic habit from $a b b a$ Dəmyanos of Däbrä Sina, in

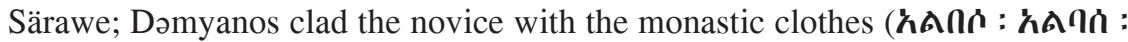

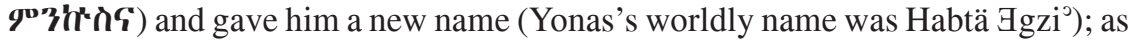
the Vita mentions, those who accepted the monastic cap, scapular and «sheep-

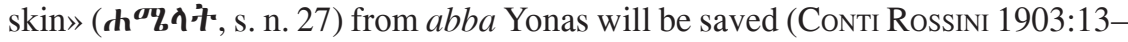
14).

8) Zä-Yohannəs of Kəbran assumed the monastic cap and scapular in Däbrä Libanos of Šäwa, from $a b b a$ Həzqəyas, who also clad him with the «clothes of the angels» after seven years of probation (SCHNEIDER 1972:9).

9) The Vita of Filəpppos of Däbrä Bizan recounts in detail how Filəppos was called to take a monastic vow and to take on the monastic clothes and «the holy

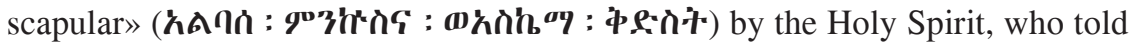
him to go to Bäkimos of Däbrä Șärabi. The Holy Spirit also informed Bäkimos about the one coming to him. Having performed the ritual according to the Mäșhafä Mənk ${ }^{w}$ əsənna, Bäkimos lay upon Filəppos the monastic habit, speaking of «the garb of our Lady Mary», «the girdle of John [the Baptist]» and «the garment of

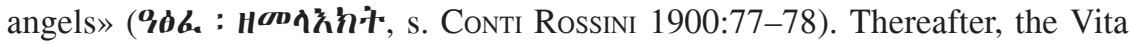
relates, somewhat vaguely, how Filəppos went into the desert and received the monastic cap and scapular «from the hands of Jesus Christ, while the Saviour spoke to and conversed with him in the likeness of $a b b a$ Ewosțatewos» (ibid. 79). The Synaxarion of Däbrä Wärq, an Ewosțatean monastery in Goğğam, repeats the story, yet in this document Filəpposos received the cap and scapular in Betä Pänțälewon (near Aksum?), and Christ spoke to him in the likeness of Pänțälewon (SCHNEIDER 1978)!

10) Abunä Zär ${ }^{\supset a}$ Buruk received the «angelic habit» (here meaning: the scapular) from God; he received the «spiritual [monastic] cap» the girdle from God as well, but through the hands of abunä Täklä Haymanot and Gäbrä Mänfäs Qəddus

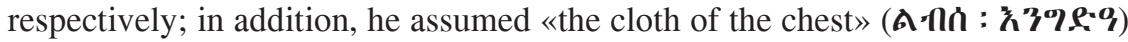
from Ewostatewos (JAEGER 1912:168-169; RICCI 1979:108);

11) Anorewos received the monastic habit from Täklä Haymanot, who in-

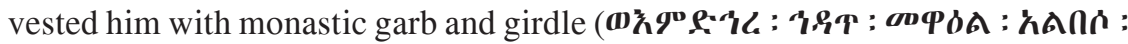

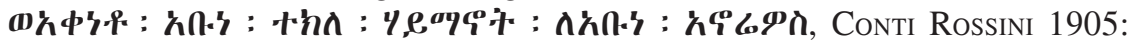


69); further on, it is related that Anorewos wore «the rope belt» (zähabl qənat; ibid., 77).

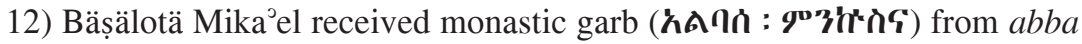
Anorewos, at Däbrä G"äl (ConTI RossinI 1905:14).

13) The Vita of Hədan $\mathrm{Mo}^{\circ}$ a reports that this holy monk received «the monkish

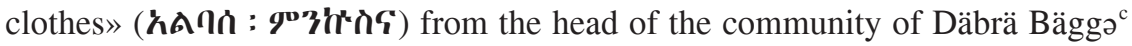
(MS EMML 2353, fol. 6ra-va).

14) The Vita of Bägg ${ }^{c}$, a monk from Däbrä Hayq Esțifanos, does not relate how he assumed the monastic habit; after the report about Bägg ${ }^{c}$ 's entering the community, the author concentrates on the strictest abstinence of Bägg ${ }^{c}$ (he did not drink water for many years; MS EMML 1960, fol. 61 va).

15) According to his Vita, Yohannəs Məsraqawi left his family at the age of 22 and spent many years in «the house of Isidor» (in Egypt) serving as räd ${ }^{\circ}$ and

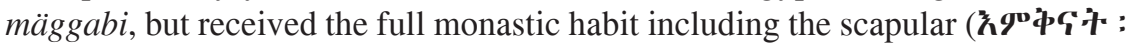

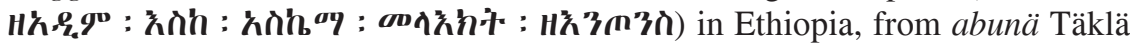
Haymanot (MARRASSINI 1984:180-183). Another piece of the tradition, separate

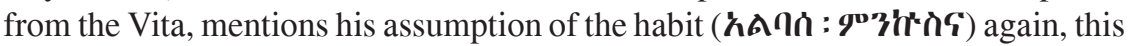
time without details; here the hagiographer claims that, Yohannəs has a privileged position as compared to the other 12 pupils of Täklä Haymanot, since he was the first to received the monastic habit from the latter (ibid., 342-345; cp. also ibid., LXVII-LXX, C-CI)

There are some examples from the traditions related to Däbrä Libanos of Šäwa:

16) According to the Waldəbba recension of the Vita of Täklä Haymanot, the Saint accepted in his community Abel «a son of Zeb Dähar» and, after an inter-

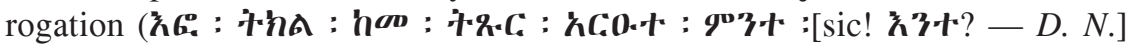

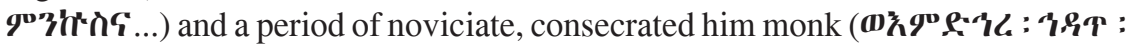

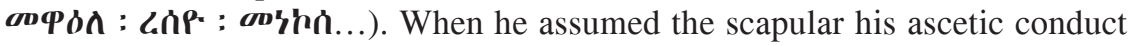
became so rigid that Täklä Haymanot had to restrain him, but soon he allowed Abel to live «in the desert». It is reported that as soon as he took on the «scapular

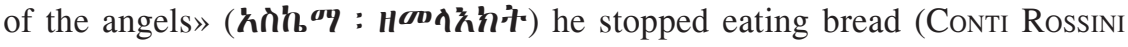
1895:118).

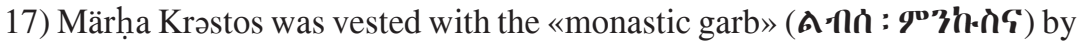
abun $\ddot{a}$ Yohannəs Käma, being of a young age, and after a certain time he received the monastic cap and scapular (KuR 1972:24-25).

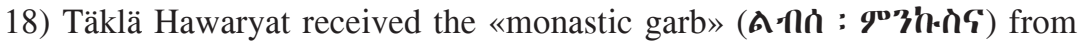
Yoḥannəs Käma, in Däbrä Libanos (CoNTı Rossinı 1910:71).

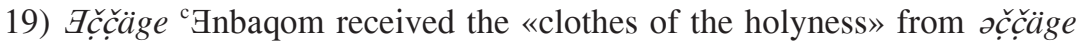
Pețros («Egli disse: figlio mio, da questo momento sii monaco e indossa le vesti

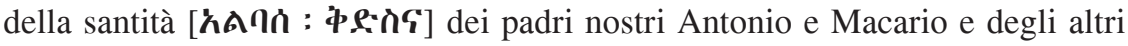
Santi...»), after a period of noviciate and religious education (RICCI 1955-1958:81).

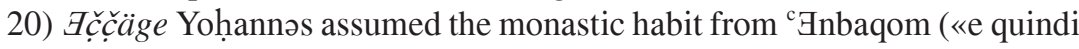
gli vestì l'abito monastico e fece discendere su di lui le benedizione del Signore», RICCI 1969-1970:176), later on the Vita reports that ${ }^{c}$ Gnbaqom was also his father in respect of the scapular («gli era padre nei riguardi dello scapolare [askiemmā]», ibid., 191). 
21) Habtä Maryam, another representative of the community of Däbrä Liba-

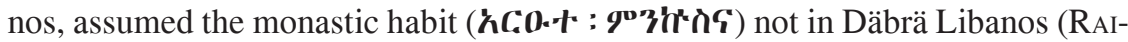
NERI 1990:37).

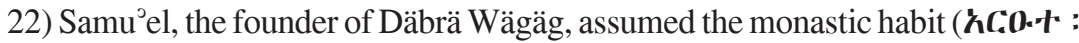

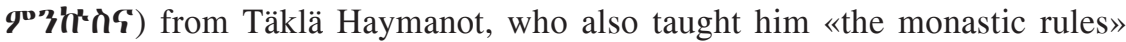

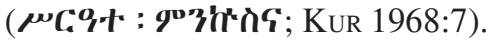

\section{SUMMARY}

The study deals with an episode from the history of the Ethiopian Church that relates to Iyäsus $\mathrm{Mo}^{\circ} \mathrm{a}$ and his pupil Täklä Haymanot, both famous saints and $13^{\text {th }}-14^{\text {th }}$-cent. abbots of Dabra Hayq Gstifanos and Däbrä Libanos of Šäwa respectively. Known mostly from the hagiographic documents and considered crucial for Ethiopian history, the episode centres on Iyäsus Mo'a's and Täklä Haymanot's assumption of the monastic habit, namely on the sequence in which they bestowed on each other the articles of the monastic attire. The episode has been analysed and interpreted by scholars in different ways, and has been thought to be important for the reconstruction of the history of the relationship between Dabra Hayq and Däbra Libanos — the most important centres of the Ethiopian monasticism. The present article continues this discussion and attempts to reach a better understanding of the sources and, consequently, the events they describe. The paper examines the episode in light of what we know about real Ethiopian monastic practices. Thereafter, it attempts to reconstruct the development of the event's representation in the hagiographic sources and its traditional perception, by clarifying the textual history of the most crucial hagiographic documents containing the episode (including, e. g., the discussion on the «short Vita of Iyäsus $\mathrm{Mo}^{ } \mathrm{a}$ » from MS. Țānāsee 164 = Dāgā Esțifanos 53), and by inquirying the references to this episode found in other sources. 